\title{
Studies on the determination of cytoplasmic oestradiol receptor in human breast cancer
}

Citation for published version (APA):

Ralet, P. G. F. A. H. (1981). Studies on the determination of cytoplasmic oestradiol receptor in human breast cancer. [Doctoral Thesis, Maastricht University]. Rijksuniversiteit Limburg. https://doi.org/10.26481/dis.19810514pr

Document status and date:

Published: 01/01/1981

DOI:

10.26481/dis.19810514pr

Document Version:

Publisher's PDF, also known as Version of record

\section{Please check the document version of this publication:}

- A submitted manuscript is the version of the article upon submission and before peer-review. There can be important differences between the submitted version and the official published version of record.

People interested in the research are advised to contact the author for the final version of the publication, or visit the DOI to the publisher's website.

- The final author version and the galley proof are versions of the publication after peer review.

- The final published version features the final layout of the paper including the volume, issue and page numbers.

Link to publication

\footnotetext{
General rights rights.

- You may freely distribute the URL identifying the publication in the public portal. please follow below link for the End User Agreement:

www.umlib.nl/taverne-license

Take down policy

If you believe that this document breaches copyright please contact us at:

repository@maastrichtuniversity.nl

providing details and we will investigate your claim.
}

Copyright and moral rights for the publications made accessible in the public portal are retained by the authors and/or other copyright owners and it is a condition of accessing publications that users recognise and abide by the legal requirements associated with these

- Users may download and print one copy of any publication from the public portal for the purpose of private study or research.

- You may not further distribute the material or use it for any profit-making activity or commercial gain

If the publication is distributed under the terms of Article $25 \mathrm{fa}$ of the Dutch Copyright Act, indicated by the "Taverne" license above, 
RIJKSUNIVERSITEIT LIMBURG TE MAASTRICHT

\title{
STUDIEE ON THE DETERMINATION OF CYTOPLASMIC OESTRADIOL RECEPTOR IN HUMAN BREABT CANCER
}

\author{
ACADEMISCH PROEFSCHRIFT \\ ter verkrijging van de graad van doctior in \\ geneeskunde \\ aan de Rijksuniversiteit Linburg te \\ Mastricht \\ op gezag van de rector magnificus \\ Prof. Dr. W.H.F.W. Wijnen \\ Hoogleraar in de faculteit der Geneeskunde, \\ volgens besluit van het college van Dekanen \\ in het openbaar te verdedigen \\ op donderdag 14 mei 1981 te 16.00 unr \\ in de aula wan de uniwersiteit \\ iungersestrat 53
}

Phillppe Guy Fernand Arthur Hector Ralet

geboren in Charleroi 

promotores: Prof. Dr. P.J. Brombacher

Prot. Dr. H.C. Hemker

referenten: Prof, Dr. H. Tuchmann-Duplessis

Prof. Dr. J.M. Greep 
A Exmy eit Didier 
Bij het voltooien van dit proefschrift hecht ik ex an jegens allen die op enigerlei wijze hun medewerking hebben verleend, mijn erkentelijkheid wit te spreken:

Hooggeleerde Brombacher, hooggeachte promotor, voor thw nimer aflatende stimulerende leiding tijdens thet onderzoek ben ik $U$ zeer dankbar.

Hooggeleerde Hemker, Uw kritische en bemoedigende belangstelling was voor mij een voorturende steun.

Gaame spreek ik ook mijn dank uit Jegens Bestuur en Directie wan het Dewever-Ziekenhuis te Heerlen voor de gelegenteid mi.jgeboden, om in de laboratoria van het ziekenhuis naast mijn normale werk dit wetenschappelijk onderzoek te verrichten.

Zeergeleerde Gijzen, wan de gastvrije ontwangst in het isotopenlaboratorium en liw vele practische raadgevingen heb ik bij voortdutr mogen profiteren; darvoor mijn harcelijke datak.

Zeergeleerde mevrow Pinckaers-Plasschaert, Uw cordiale hulp bij het verschaffen van te onderzoeken material stel ik zeer op prijs. Hooggeleerde Tuchmann Duplessis, hooggeleerde Greep, thet is mij een eer $U$ te danken woor $\mathrm{U}$ bereidwilligheid als coreferemten op the treden.

Zeergelleerde Davies, Uw immer charmat comnentar bij het bewerken van de engelse tekst was mij werkelijk tot steun,

Voor hun cnonderbroken interesse in de resultaten van de analyses dank ik de chirurgen in de regio.

Dank ben ik verschuldigd aan de medewerkers van de afdelingen $k l i-$ nische chemie en isotopenlaboratorium van het Dewever-ziekenhuis voor de prettige sfeer warin ik dit werk heb kunnen verrichten. zonder anderen tekort te doen noem $i k$ met name mej. Deckers en de heren Marell en De Hal wan Anckeveen.

De werzorging vam het manuscript its op woorteffelijke wijze behartigd door mevr. Poetschlack-Sieler; hartelijk dank hierwoor.

Tenslotre, mar zelker niet op de laatste plats, ben ik special dank verschuldigd aan mijn vrouw woot har niet aflatende steun en bemoediging bij mijn werk, terwijl juist zij nog extra belast was door mijn soms noodzakelijkerwijs tekont schietende aandacht woor ons gezin. Dank ook aan bidier die, hoewel hij zijn vader veel heeft moeten missen, bierover nimer heef t geklagd. 


\section{CONTENTS}

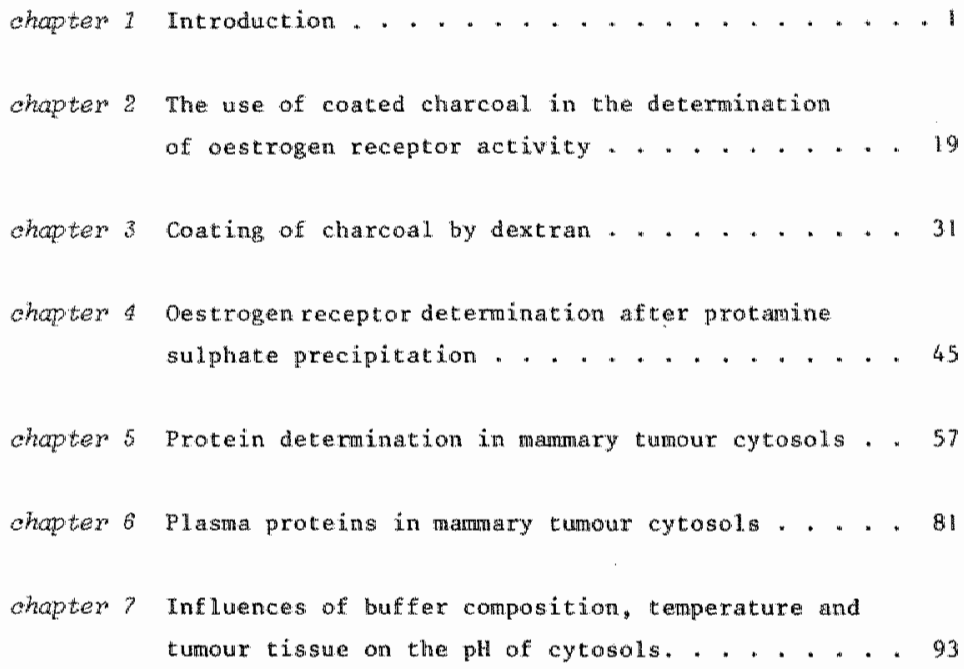


chapters I

INTRODUCTION

OESTROGEN HORMONES ANDO RECEPTDR PROTEINS

In the study of cancer of the breast much attention has been paid in recent years to procedures interfering wh the endocrine status of the patient. Both surgical treatment and hormonal therapy have. been used extensively (I). Varlous response rates have been observed but few if any patients with metastases could be cured, although much progress has been made in the understanding of treatment.

Since the first observation ( 8 ) of endocrine influence on the growth and recurrence of breast cancer, many investigators have tried to find a better pathophysiological basis for the treatment of this upe of malignancy. The recent introduction of reliable laboratory assays for hormone receptors has simplified the selection of therapy in many patients ( 3 ). The ides that hormones act through receptor proteins present in some tumours and not in others has now been generally accepted $(4,5)$ and this has been contirmed by the fact that the response to endocrine therapy is much better in patients whose tumours contain oestrogen receptors than in the destrogen receptor negative patients $\left(\theta^{*}\right)$. It can be stated that the greatest valute of the determination of oestrogen receptor in tumour tissue is the ability of such tests to identify patients who can be spared either unnecessary ablative surgery of endocrine glando or resultiess administration of homonal drugs. Evidence has been presented $(7,8,9)$ suggesting that patients with oestrogen receptor positivity have a better prognosis than those with receptor negatiwity. It is now certain that the symptoms of advanced breast 
cancer car be relieved, sometimes for up to 10 years, by the adminiteration of hormones, endorime ablation, chemotherapy or combinations of these approdiches (1). Moreover, after oophorectomy or the adrintetration of westrogens, the fraction of cellus symthegíging DNA falls in patients wo respond to endacrine therapy, but not in patients wo fall to respond (10), which is another support for the influence of oestrogen steroids on tumour protein symthesis in the pregence of oestrogen receptors. In clinical studies of the response rates or fallure of endocrine therapy a nuber of criteria for objective remission have been used, such as considerable decremge in the sige of measurable lesions, no progress of other Iesions and roentgemographic evidence of healing of atcolytic metastases (11). Unsatisfactory correlation between westrogen receptor determinations in vitro and remission rates led to the introduction of the determination of progesterone receptors in cytosiols from the same tissue in which oestrogen remeptors had been determined. As far a remigion was concerned the predictive value of these combined receptor data was clearly betcer than for oestrogen receptor walues alone. This cam perhaps be explained by the bypothesis that the synthesis of the progesterone receptor protein is positively influenced by the presence of oestrogen receptor complexes (12). The indication of renission in clinical studies can be given in several ways. A first passibility, generally used, is to calculate the rate of response to therapy in different groups of pacients/tumours, classified according to oestrogen receptor possitiwity $(E R+)$ or negativity (ER-) in combination with progesterone receptor positivity ( PgR +) or negativity ( PgR-). It has been reported that in parients with $E \mathrm{E}+/ \mathrm{PgR}+$ tumours good remisgion rates (77\%) were observed in contrat to ER+/PgR-tumours $(27 \%)$ and $E R-/ P g R$ w tumourg $(11 \%)(13)$. More saphisticated schemes for and ys of clinical data have also been proposed giving "doseresponse" curves in a four - paramater logistic model (14). Here the hornone receptor values were not just given as positive or negative but it appeared that the experimentally deterained receptor concentrations are important for the prognosis of treatment. 
Progesterone receptor walues were studied at different levels of oestrogen receptor values and vice verga in relation to remission on treatment. Altogether, there is ample evidence now that the determination of oestrogen receptors in tumours of the breast is very important for the treatment of patients afflicted with these cumours. In a special report of a "consensus-development meeting" on "Steroid Receptors in Breast Cancer" (National Institutes of Health, 1979) it is stated (3): "Only with the recent study of the oestrogen receptor (ER) content of breast cancer tissue has there been any success in identifying those patients most likely to benefit from endocine therapy .... Thus, results of $\mathrm{E}$ assays provide waluable information for making the clinical decisions on the type of therapy to be employed ...." Results presented at that meet ing indicated generally good agreement in receptor assays of primary and metastaric tumour samples from the same patient but changes in sequential receptor assay occurred from receptor positivity to negativity.

Fram the clinical inportance of the determination of oestrogen hormone receptors it follows that atcention has to be pald to the mechanism of action and the very nature of these proteins. All known hormone receptors are proteins that contain a site or sites to which the hormone can bind. The role of a receptor is in the first place to distinguish a particular signal from the specific hormone for which the cells concerned are targets and next to relay this signal in such a way that the appropriate cellular response follows. In general, the conformation of the receptor is changed by binding the hormone. steroid hormone receptors are found in the cell cytoplasm but as soon as the steroid is bound the hormone receptor complexes migrate to the nucleus where they are bound to the chromatin and protein synthesis is greatly influenced ( 4$)$. It is not clear whether the hormone originally penetrates the cell memilyras simply by passive diffusion or if specific uptake mechanisms are active (Is). An essential characteristic of an oestrogen target cell, as found in mamary gland or uterine tissue, is the capacity to bind oestradiol specifically and with high affinity. Stexoid receptors 


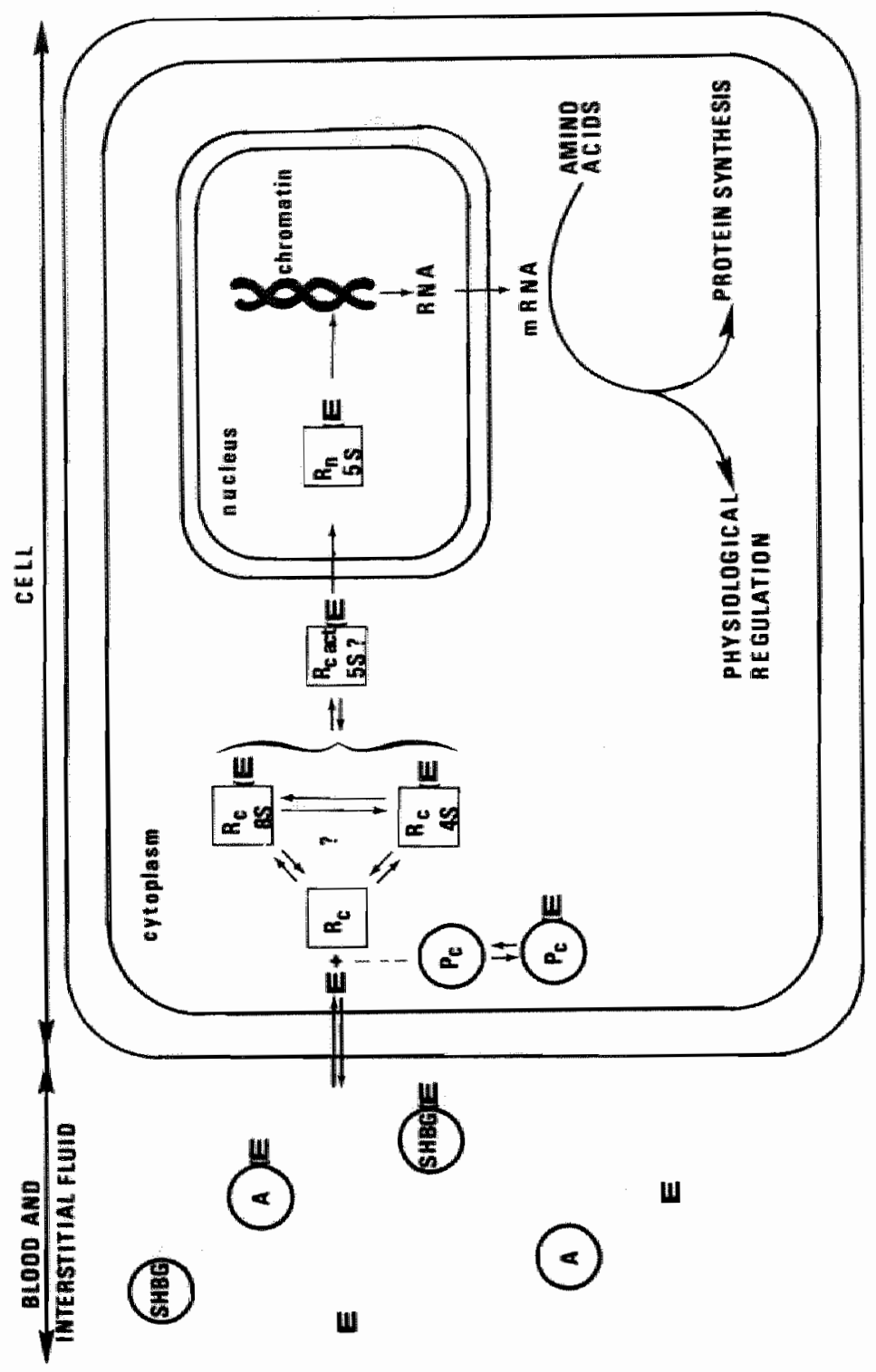




\section{figure $1-1$}

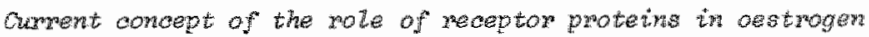
hormone cation.

SHBG: sex homone binding globulim

A : albumin

$E$ : destrogen

$P_{C}$ : cytoplasmic protein

$R_{C}$ : aytoplasmio neceptor

$\mathrm{R}_{\mathrm{C}}-\mathrm{E}$ : cytoplasmic receptor - opgtrogen conples

$\mathrm{R}_{C}$ act-E : activated cytoplasmic receptor - oestrogen complex

$\mathrm{R}_{C}-\mathrm{E}$ : reiclear receptor - aestrogen complex

RNA : mbonuleire adid

MRNA : messenger mibonuctedic acrd

$($ : non specifia binding protein
$\square$ : specific binding protein ireaptons

have been determined in cytosals prepared from target tissues. The receptor hormone complex of the mammary gland sediments at $8-9 \mathrm{~s}$ (Svedberg units) on sucrose gradients with low silit concentrations. Increasing the salt content to solutions with greater than physiological ionic strenght results in the sedimentation at $4-5 \mathrm{~s}$ (molecular weight about 70,000 ). The true molecular size of the receptor in the target cell is not known although some authors prefer the $4 \mathrm{~S}$ form $(16)$. It has been reported that $3 \times 10^{3}-100 \times 10^{3}$ receptors per cell can be found.

There are some fundanental differences between the incracellular receptor proteins and steroid binding proteins foum elsewhere, e.g. sex hormone binding globulin (SHBG) and albumin in blood plasma. The most striking difference is perthas that the equilibrium constant of dissociation $\left(K_{d}\right.$ ) is about 10 to 100 times smaller for receptor proteins than for SHBC and corresponding extracellular binding proteins. In cytoplasmic receptars $k_{d}$ "s are commonly found in the order $10^{-9}-10^{-11}$ moll/ . Destrogens bound to extracellular protedins 
provide a wast pool in equilibriw with a small anount of free hormones. The later by pasiwe diffusion pass the cellular membrane and are captured in the cytoplagm by specific receptor proteins and non-specific cytoplasmic binding proteins. It is believed that the pirmarily formed astrogen receptor complex undergoes aggregation to larger entities or activation before binding of the complex to the cell nucleus occurs (17) anc the nuclear nembrane is passed. It is not fully known what thi activation entails. Probably the conformation of the oestrogem receptor complex is changed so that a nuclear binding site on the receptor is exposed and binding to nuclear receptors occurs $\left(n_{n}-E, 5 s\right)$. The nuclear proteins and the DNA of chromatin appear to particlpate in the binding process. It has been found in oestrogen responsive systems that there are more nuclear receptors than cytoplasmic sterid receptors, so the nuclear bunding sites are never saturated in the intact cell $(18,79)$. It is understood that after binding of the oestrogen receptor complex to specific chromatin sites (geverally considered to consist of nonhistone proteims) in the nucleus, DNA transcription is induced by RNA polymerase. A specific mRNA is formed which migrates to the ribosomes in the cytoplasm where the code is translated resulting in the synthesis of specific protein. Whether steroid receptor chromatin complexes affect transcription of specific genes and thus influence protein synthesis or steroid receptor complexes themselves act as, or upon, enzymes that modify chromatin proteins is still unclear. The fact that there is a specific and pronounced influence an protein synthesis, however, is now generally accepted (figure $1-1$ ).

\section{BINDING OF STEROIDS TO RECEPTOR PROTEINS}

The models used in the biochenical analytical procedures for the study of binding phenomena of steroit hortwones to receptor proteins have been adapted following general principles of kineties of protein $1 \mathrm{hg}$ and interactions $(20)$. As non-specific binding proteins are likely to interfere in the analytical procedures a number of 
parameters must be established and evaluated. dmongst these are binding specificity, binding affinity, binding capacity and the wolecular form of the receptor proteins.

Binding specificity means that the receptor can discriminate signal from noise, in ther words that the structural differences between various steroid hormones are recognised at the nolecular level by the receptor proteins. This specificity can be estimated in witro by deteraining the relative competition between differmt types of steroid homones for binding sites on a specified receptor protein.

The binding affinity of the hormone for the receptor needs to be sufficiently high as concentrations of circulating hormones are in the range of $10^{-8}-10^{-10} \mathrm{~mol} / 1$. In the study of these affinities it must be considered that the binding is non-covalent inwolving ellectrostatic interactions as hydrogen bonding and also hydrophobic interactions. The hydrophobic interactions to same extent drive the reaction on account of the presence of hydrophobic regions on the receptor protein and the non-bydrophilic character of steroids. The final binding is prinarily the result of hydrogen bonds between charged groups on the hormone and oppositely charged groups at the complementary site on the receptor. These receptor sites also determine to some extent the binding specificity.

$$
\begin{aligned}
& {[H]+[R] \frac{k_{1}}{k_{2}}[H R]} \\
& K_{d}=\frac{k_{2}}{k_{1}}=\frac{[H][R]}{[H R]}
\end{aligned}
$$

The wathematics of the binding reaction can be conveniently deriwed from the general equations given here where [H] is the concentration of hormone, [R] is the concentration of receptor, [HR] its the concentration of hormone receptor complex, $k_{1}$ is the rate constant of the association reaction, $k_{2}$ is the rate constant of the dissociation reaction and $\mathrm{K}_{\mathrm{d}}$ is the equilibrium disgociation constant. The reciprocal of the latter is the equilibrium association constant 


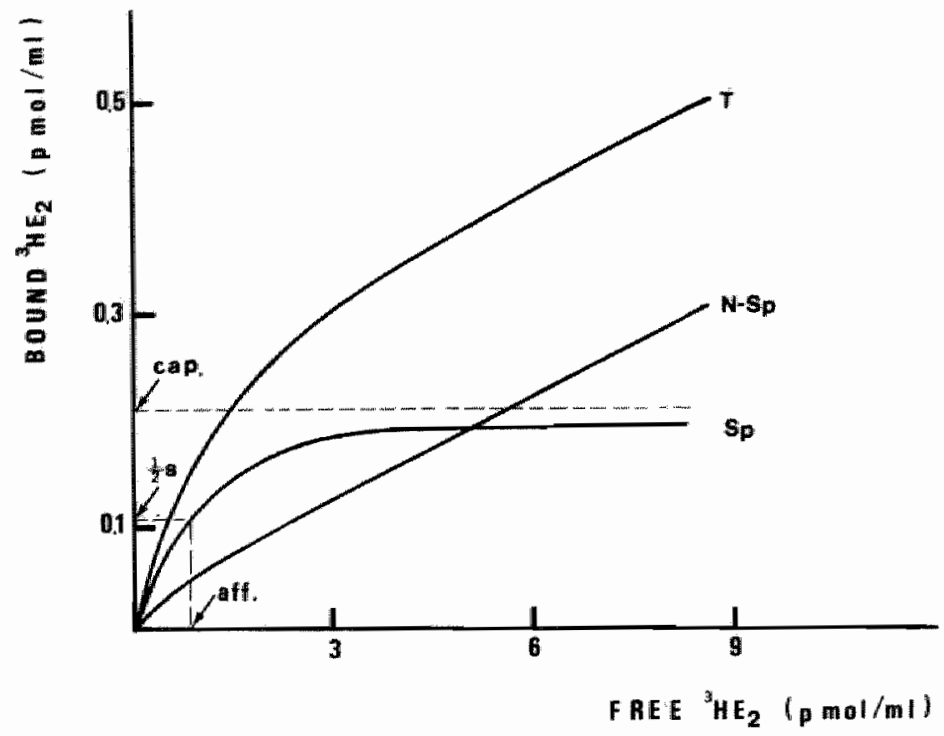

\section{figure $1-2 a$}

Binding of tritiated oestradiol by reeptor positive mamary tham oy tosol (DCC-method).

$T$ : total binding

N-Sp : Low affinity high ecpacity nom apectifie binding

Sp : apeatifio (reaptor) binding aclevated by $T-\mathrm{N}-\mathrm{Sp}$

cap. : broker line indicateg maximw specific binding aparty, i..e. redeptor content per matosot

Is : Malf maximon (acturation) binding

aff. "free homone concentration at holf saturation, equals $\mathbb{l}_{\mathrm{d}}$ 


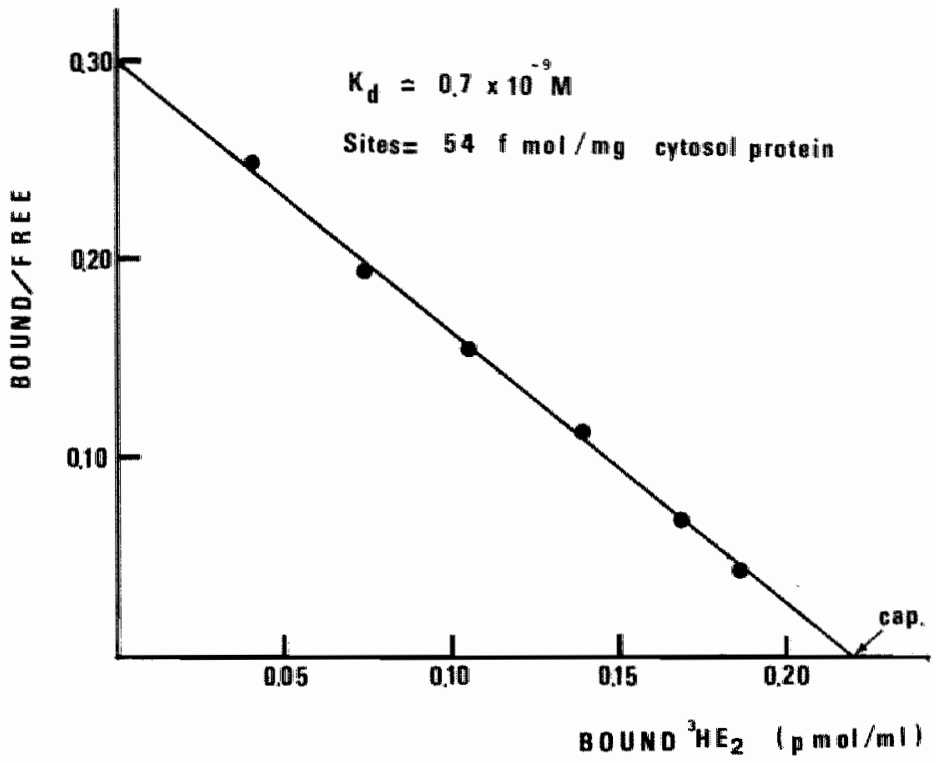

figure $7-2 b$

Scatohard analyisis of data shown in figure $1-2 a$.

cap. : maximum binding acpacity per mz cytosot

$K_{d}:$ minus inverse of slope

The protein concentration in the cytosol was $4.1 \mathrm{mg} / \mathrm{mi}$, hence the binding opacty is oalchlated as follows: receptor whes

0.220 proz/mi cytosol os 220 fmol/4.1 mig protein equals sis fentomol/mg protein. 
$\mathrm{K}_{\mathrm{a}}(\mathrm{I} / \mathrm{mol}) ; \mathrm{K}_{\mathrm{d}}$ is expressed in mol/L.

Fron the above equations, [R] and [HR] can be cancelled if the concentrations are equal, that is, if half the receptor sites are accuphed by homones. In that case. $K_{d}=[\mathrm{H}]$. This leads to an ugerul working definition of affinity, saying that the rree: concentration of hormone necessary to half-saturate receptors equals the quilibrium dissociation consant. The lower this concentration i.s, the higher the affinity of binding (figure $1-2 \alpha$ ).

Binding is usually studied over a range of hormone concentrations from $1 / 10$ th to $10 \mathrm{tines}$ the half-saturating concentration. For the interpretation of data obtained in this way, the Scacchard plot (21) is mostly used. Linear plots are obtained permitting the determination of the the dissociation constant and the total concentration of binding sites which is also called the binding capacity.

If $\mathbf{n}_{\max }$ is the total concentration of binding sites then

$$
\mathrm{n}_{\max }=[\mathrm{HR}]+[\mathrm{R}]
$$

or

$$
[R]=n_{\text {max }}-[\mathrm{HR}]
$$

Substituting [B] (concentration of bound hormone) for [HR] and [F] (concentration of free hormone) for $[\mathrm{H}]$, then

$$
[\mathrm{B}] /[\mathrm{F}]=[\mathrm{R}] / \mathrm{K}_{\mathrm{d}}
$$

and

$$
\frac{[B]}{[F]}=\frac{n_{\text {max }}-[B]}{K_{d}}=\frac{-[B]}{K_{d}}+\frac{n_{\text {max }}}{K_{d}}
$$

This is the equation for a straight line. From the graphical representation of $[B] /[F]$ ve. [B] , the $\mathbb{K}_{d}$ (minus the inverse of the slope) and $n_{\text {max }}$ (the abscissa of the intercept of the line with the $x$ - axis) can easily be read (figure $1-2 b)$.

This description of binding phenomena is employed successfully in the deceraination of oestrogen receptors. Dnfortunately, a cytosol from human tissue always contains non-specific macromolecular hormone bindirg components, e.g. tissue proteins and often serum proteins 
(hwman serug albumin). There are differences, however, between the true hormone receptor and nonwreceptor biading proteins. The dissociation constant for non-specific hormone protein complexes are much higher than for the hormone receptor complexes. On the other hand, non-specific binding proteins are often abundanty available leading to a large binding capacity in the cytosol. Scateliard analysis performed on a series of concentrations of the hormone sthows the existance of specific and non-specific binding (figure $1-2 a)$. By adding considerable excess of radio-inert hormones to the assay system the binding of tracer by the true receptor is considerably depressed by competition. In this way the degree of non-specific binding in a given system can be determined. The binding capacity of homones is expressed by the molar amount of hormone bound per $\mathrm{mg}$ protein or per HE DN, the latter expression being used for receptor concentration in homogenates of call nuclei.

The last parameter to be considered is the molecular form of the receptor protein. Although most receptor protelins have been found in gradient centrifugal analysis to sediment as $8 \mathrm{~s}$ macromolecules the occurence of $4 \mathrm{~s}$ proteins thas also been reported. The sedimentation constant found appeared to be dependant on the ionic strenght of the medium used in the analysis. There is no firm agreement on the actual native form of the receptor protein (22). It has been reported that the receptor changes from low aftinity 4 s protein towards high affinity activated (perhapis 5 s) receptor protein just by the binding of oestradiol ( 23 ). The possibility is not excluded that tumours demonstrating hormone binding only in the 4 s region are less hormone dependant than those containing 8 receptor proteins (2A).

TECHNIQUES FOR THE DETERMINATION OF CYTOPLASHIC OESTROGEN RECEPTORS

The presence of the cytoplasmic receptor proteins in target tistses can be demonstrated both in tissue slices and in cytosals. "The latter are protein extracts prepared by removing cellular debrig and nuclei 
from tabue homogemates by centrifugation at low temperature and carefulty chosen pll to avofid irreversible damage to the receptor protelins.

Tissue sice analysis is performed by incubating tissue sices in sutable medium containing radioactive pestradol. The sterojd is bound to the receptor proteins in aitu and can be detected there. Detection of non-specific binding is performed by adding excess of competitor 1 igands, e.g. "cold" oescradiol or synthetic steroids. Another poisibility ils the demonstration of receptor sites by immunafluoregcence techniques avolding the neressity to use radioactive tracers. A drawback of these procedures is the imposibility of quantitative analysis. Furthermore it is difficult to find tissue sices which are truly representative for the whole tistue from wich they have been taken $(25,26)$.

A number of techniques for the quanticative determimation of the cancentration of the specific receptor in cytosals has been described. The principles of all methods are the binding of radioactive oestradiol (tracer) by the receptor protein, the renoval of excess tracer and the estimation of the ratio of specific to non-specific binding. Several technigues are used of which the most important are 1isted bellow:

Dextran coated charcoal (DCC) analysis (27, 28). This is probably the most often used method in so called protein binding analysis. In receptor assay it consists of the incubation of cytosol samples with radioactive oestradiol which is completed after some hours by adding dextran coated charcoal. The latter is supposed to adsorb only small molecules, excess tracer, leaving undisturbed the oestradiol receptor complex. Rexoving the charcoal by centrifugation leawes only the protein-bound tracer in the solution and the radioactivity of the tracer-protein complex can be determined. The method is elegant and can easily be performed. However, the separation of bound and free tracer of ten deviates from what theoretically was expected, as will be described later on. 
Sucrosie density gradient assay (SGD) (29).

The sucrose density gradient ultracentrifuge assay is based on the separation of proteins due to sedimentation. Aliquots of cytosols are incubated with radioactive oestradiol with or without an excess of unlabelled competitive ligand (e.g. diethylstibestrol or another oestrogen-like compound) to determine total and non specific binding. Excess steroids are either removed by adding DCC and subsequent centrifugation, or the reaction media are directly submitted to ultracentrifugation. In the first case aliquots of the remaning supernatant are then layered on top of a cold linear gradient of sucrose. After ultracentrifugation (about $300,000 \mathrm{~g}$ ) during 16 hours the tubes are punctured at the bottom and the comtents taken in small fractions for the measurement of radioactivity. The fraction containing considerable tracer-protein complex is supposed to be the "receptor-fraction", found by comparison of experiments with and without excess cold steroid to detect non-specific binding.

Protamine precipitation assay $(30,31)$. Another method having considerable advantage at first sight is the use of protarine sulphate to precipitate receptor protein. Samples of cytosol are mixed with a protamine sulphate solution. Upon centrifugation coprecipitation of the latter with certain protein fractions (amongst which all receptor proteins) occurs, forming a thin film on the bottom of the tube. After decanting the supernatant a buffer containing the tracer is added to the tubes. Radioactive oestradiol is bound to receptor proteins during subsequent incubation and the excess tracer is removed by decanting the contents of the tube and rinsing with buffer. Radioactivity remaining in the tubes is bound to the precipitated protein film and is essily mewared, giving an indication of the receptor concentration. A digadvantage is that the necessary rinsing of the tubes brings the risks of loosing protein and dissociation of receptor-tracer complex. These phemoma could cause errors in the analysis, j.e. underegtimation of receptor content. Nevertheless, the method seems to be competicive with the DCC technique. 


\section{Gel filtration $(32)$.}

Gel fijtration i another general procedure used for separation and igalation of proteins from low molecular weight material in soluticns, The principle of this technique has also been applied in the determitation of oestrogen receptor protein in eytosials. Incubation of the cytosol with tritum-labelled oestradiol under suitable experimental conditions leads to saturation of the receptor siteg. Proteins with adhering tracer can then be separated from exces tracer by gel filtration. Problems arise in some experiments on account of chromatographic adsorption effects of the colum medium resulting in loss of tracer-receptor complex, and also in the necessary differentiation of complexes of binding proteins with radioactive steroid in the macromolecular fraction separated in this technique. Furthernore dissociation of the oestradiol receptar complex may cause serious errors.

Electrophoretic techniques $(33)$.

The last techniques to be mentioned here are agar gel electrophoresís and polyacrylamide gel electrophoresis. These procedures are sometimes used to separate the proteins in the cytosol whereupon the electropherogran is either inculbated th tracer as such or cut into thin slices containing the different protein fractions which were studied seprately. Another posibility is to separate receptor-tracer complex from free receptor by electrophoresis after prior incubation. Severe problems arise on account of considerable dissociation of these complexes and the dematuration of the labile receptor proteins during the electrophoretic procedure.

\section{PURPOSE OF THE PRESENT STUDY}

From the preceding paragraphes it is clear that auch was left undiscussed. The necessity of detemination of oestrogem-receptor concentration in mamary gland tumours is generally agreed. The procedure to be chosen is a difficult problem. Some methods were less 
suitable for quantitative determination of receptor concentration in cytosols (gel filtration and gel chromatography, electrophonesis) but were useful in the characterization of the recoptor proteins (3). In other methods great care had to be taken to avoid denaturation of receptor proteins dwe to changing ionic strength and local heat development in electrophoretic techniques. It is not surprising that the DCC method is still the procedure of choice it many laboratories wilst other investigators tend to use the sucrose density gradient procedure or the protamine sulphate precipitation technique.

In our laboratory the DCC method was used during some years but full satisfaction was not found. The main purpose of the present investigation therefore was the intensive study of parameters invalved, such as the efficiency of separating bound and free tracer by dextran coated charcoal and the cause of loss of radioactivity supposed to be protein bound. Another fundamental problem appeared to be the accurate and reproducible detemination of very low protein concentrations in sometimes rather small cytosol samples. Furthermore in the standardization of the determination of oestrogen receptors the importance of the pli of the reaction medium was of ten neglected. This was a reason for close investigation too.

In our opinion the predictive value of the detemination of harmone receptors in cytosols from human tissues can most probably be improwed by rigorous standardization of the technical aspects of the assay paying attention to all relevant parameters.

\section{REERENCES}

1. Henderson, C. and Canellos, G.P. (1980) Cancez of the breat: the past decada. En. I. Med. $302,17-30$ and $78-90$

2. Heatson, G.T. (1896) On the treatment of inoperable cases of carcinoma of the mama: Suggestions for mew method of treatment with 11lustrative cases. Lancet $11,104-107$ 
3. De sombre, E. E. (1979) steroid receptors in breast cancer.

N. Enigl, J. Med, 301, $1011-1012$

4. Jensen, E.V. and Jacobson, H.J. (1960) Fate of steroid estrogens in target tissues. Pag. 161, in: Pincus, G. and Vollmer, E.P. (Eds.) Blological activities of sterojds in relation to cancer (Acardenic Press, New Tork)

5. Gorski, J., Toft, D., Shyamala, G. Smith, D. and Wotides, A. (1968) dorwone receptors: studies on the interaction of estrogen with the uterus. Recent. Prog. Hora. Res. 24, 45-80

8. Mc Guire, H.L.. (1980) Sterold receptors in breast cancer treatment gtrategy, Recent. Prog. Horm. Res. 36, $134-156$

7. Hension, J,C., Lecletcq, G., Longeva1, E., Deboel, M.C., Mattheilem, h.H. and Heimamn, R. (1975) Estrogen receptors: Prognostic significance in breast cancer. Pag. $57-72$, in: Mc Guire, N.L. . Carbone, Carbone, P.P. and Nolloner, E.P. (Eds.) Estrogen recepters in human breast cancer (Raven Press, New York)

8. Jensen, E.V. (January 27, 1978) Hormone dependency in human breast cancer, First Innsbruck Winter Conference on Biochemistry in Clinical Medicine, Innsbruck, Austria

9. Knight, W. IIT, Livingstone, R.B., Gregory, E.J. and Mc Guire, W.L. (1977) Absent estrogen receptor and increased recurrence rate in breast cancer (abs. C19). Proc. Afr. Assoc. Cancer Res. 18,271

10. Nordenskjöld, , . Löwhagen, T. "Westerberg, H. and Zajicelk, I. (1976) ${ }^{3} \mathrm{H}$-Thymidine incorporation into mamary carcinoma cells obtained by needle aspiration before and during endocrime therapy. Acta Cytol. (Baltinore) 20, 137-143

11. Degenshein, G.A., Ceccare11i, F., Bloom, N.D. and Tobin, E.H. (1979) Hormone relationships in breast cancer. Current problens in surgery 16, $\mathrm{nr} .6$, pag. 24

12. thorwitz, K.B. and Mc Guire, W. L. (1979) Estrogen control of progesterone receptor induction in human breast cancer. Adw" exp. med. and biol. $117,95-110$

13. Mc Guire, W.L. (1980) Steroid receptors in breast cancer treatment, Rec. progress horm. res. 36, 1411 
1: Rodbard, D. (1980) Steroid receptors in breast cancer treatment (discussion). Rec. progress horm. res. $36,148-149$

15. Baxter, J.D. and Funder, J. W. (1979) Hormone receptors. N. Eng. J. Med. $301 * 1149-1161$

16. Hilf, R. and Wittliff, J.L. (1974) Characterization of human breast cancer by examination of cytoplasmic enzyme activities and estrogen receptors. Pag. 103-130, in: Mc Kerns, K. W. (Ed), Mormones and cancer (Academilc Press, New York)

17. OMaIley, C.L. (1978) Bh: Steroid hornone action: recent advances. Ann. Intern. Med. 89, 694-701

20. Willians, D. and Gorski, J. (1972) Rinetic and equilibrium analysis of estradiol in wterus: a model of binding-site distribution in uterine cells. Proc. Natl. Acad. Sci. U.S.A. $69,3464-3468$

10. Chamness, G.C., Jemnings, A.W. and MC Guire, H.L. (1974) Estrogen receptor binding to isolated nuclei: a nonsaturable process. Biochemistry $13,327-331$

20. Clark, J.H. and feck, E.J.,.Jr. (1977) Steroid hormone receptors, basic principles and measurements. Pag. I (2), in: Schrader, W.T. and $0^{\prime}$ Malley, B.W. (Eds.) Laboratory methods manul for hormone action and molecular endocrinology (Department of Cell. Biology, Baylor College of Medicine, Texas Medical Center, Houston, Texas)

21. Scatchard, G. (1949) The attractions of proteins for small molecules and ions. Ann. M. Y. Acad. Sci. 51, 660-672.

22. Erdos, T., Bessada, R. and Fries, J. (1977) Multiple molecular forms of the uterine estradiol receptor. Pag. 113, in: Agarwal (Ed.) Multiple molecular forms of steroid hormone receptors (E1sevier, Amsterdan)

23. Notides, A.C. Heichmann, B. N. , Lerner, M. and De Boer, W. (1979) The role of ligand-binding as a determinant of the structure and activation of the estrogen receptor. Pag. 297-307, in: Leawt, w. and Clark, Jall. (Eds.) Steroid hormone receptor systems (Plenum Press, New York)

24. MC Carty, K.S., Jx, and Mc Carty, K..S., Sr, (1977) Steroid homone 
receptors in the regulation of differentiation: a rewiew. Aran. I. Pathol. $86,705-744$

25. Pertschuk, L.P., Tøbin, E.H., Brigati, D.J., Kim, D.S., Bloom, H.D., Gaetjens, E., Berman, P.J., Carter, A.C. and Degensheim, G.A. (1978) Immunofluorescent detection of estrogen receptors in breast cancer. Cancer $41,907-911$

26. Sin Hang Lee (1979) Cancer cell estrogen receptor of human manumary carcinoma. Cancer $44,1-12$

27. Korerman, S.G. and Dukes, B.A. (1970) Specific estrogen binding by the cytoplasm of human breast carcinoma. J. C1in. Endocrinol. Metab. $30,639-645$

28. Cardner, D.G. and WAttliff, I.L. (1973) Specific estrogen receptors in the lactating mamary gland of the rat. Biochemistry $12,3090-3096$

29. Wittliff, J.L. and Savlov, E.D. (1975) Estrogen binding capacity of cytoplasmic forms of the estrogen receptors in human breast cancer. Pag. $73-86$, in: Mc Guire, W.L. (Ed.) Estrogen receptors in human breast cancer (Raven Press, New York)

30. Steggels, A.W. and king, R.J.B. (1970) The use of protamine to study $\left[6,7-{ }^{3} \mathrm{~K}\right]$ oestradiol -178 binding in rate uterus. Biochem. J. $118,695-701$

31. Allegra, J.C., Lippman, M.E., Thompon, E.B., Simon, R., Barlock, A., Green, L., Huff, K.K., Do, H.M.T. and Aitken, C. (1979) Distribution, frequency, and quantitative analysis of estrogen, progesterone, androgen, and glucocorticold receptors in human breast cancer. Cancer Research 39, 1447-1454

32. Singlakowita, An, Mohindra, R., Brooks, S.C., Vaitkevicius, V.K. and Bremnan, M.J. (1:975) Clinical cotrelation of endocrine therapy and estrogen receptor. Pag. 131-149, in: Mc Guire, W.L. (Ed.) Estrogen receptors in human breast cancer (Raven Press, New York)

3h. Wagner, R.K. (1978) Extracellular and intracellular steroid binding proteins. Act Endoctinol. Kbh, Suppl, 218 
chate tere 2

\section{THE USE OF COATED CHARCOAL IN THE DETERHINATION OF OESTROGEN RECEPTOR ACTIUITY}

Published in Eur. A. Nucl. Med. (1981)

Ph.G.F.A.H. Ralet and P.J. Brombacher

\section{ABSTRACT}

Destrogen receptor activity in manmary tunour and healthy tissues was determined by using a method of incubation with coted charcoal. It appears that both increased charcoal concentration and prolonged incubation lead to erroneous results, which are probably due to lass of receptor protein. It is concluded that receptor activity assays must be performed under strictly standardized experimental conditions.

\section{INTRODUCTION}

The separation of bound and free tracer is a crucial polnt in every radio-immunoasay. On this subject averal nethods have been published $(1,2)$ of which the dextran coated charcoal twethod and solid phase systems are most often used.

The principle of coating chareoal for the separation of bound from free tracer is the partial inactivation of the active charcoal so that large molecules can no longer be adsorbed, whereas smaller molecules can still penetrate to the charcoal surface and be adsorbed 
there.

One of the wether point in the procedures described is that a coating excluding all large molecules and leaving the possibility for all wall wolecules to be bound, is rather difficult, if not virtually impossible, to achieve. If often happens that ever larger molecules, because of the imperfect coating, are still bound whilst more thorough coating leads to incomplete adsorption of the free tracer. Por this reason the use of coated charcoal leads to decreased reliability in the method that we use for the estimation of oestrogen receptor in mammary tumour tissue cytosols. In this paper demonstrate the influence of time of incubation and amount of coated charcoal uged on the outcome of the analysis.

In the estimation of oestrogen receptors in cytosols from hum tisgue homogenates we followed the principles of the EORTC breast cancer co-operatiwe group $(3,4)$. In this group it has been indicated that the charcoal adsarption technigue has to be retained as the standard procedure, wh the option of using more refined techniques when they become avallable. For thibi reason we studied the influence of coated charcoal in our estimations and we were rather disappointed to see the great influence on the outcone of the analysis by changing the conditions of the assay, especially concerning the amount of charcoal and time of incubation. We used cytasols from the following samples:

a. prool of lyophilised calf uterus $(n=43)$;

b. frozen calf uterus that afterwards has been homogenised and a cytosol prepared;

c. frozen human mantary carcinoma tissue, sestrogen receptor positive;

4. pool of 36 frozen mamary cancers, aestrogen receptor positive;

- pool of healthy human (glandular) breast tissue obtained from plastic surgery patients $(n=11)$;

f. pool of 28 human mamary cancers, oestrogen receptor negative. A cytosol is defined as oestrogen receptoz positive $(E R+)$ when 9 fmal ${ }^{3}-E_{2}$ or more is specially bound per mg protein. This is 
true for clisses ame. Cycosols from healthy mamary breast insue do bind from 10 to 15 fmol ${ }^{3} \mathrm{H}^{2}-\mathrm{E}_{2} /$ mig protein (class e), whereas ER- cytosols all bind less then 9 tmol/mg protein. For the cytosolg mentioned above, the ostrogen receptor values were respectively" $a: 65.2, b: 54.0, c: 40.1, d: 77.7, e: 10.6$ and $f: 3.6$ frol $/ \mathrm{mag}$ protein.

These values clearly demonstrate the difference between for * amd $\mathrm{ER}$ - tissues. Of course, the indival examples withn these groups can be expected to show a wide range of oestrogen receptor valueg and this is andeed found.

\section{MATERIALS AND METHODS}

\section{A. Steroids}

1. $2,4,6,7,16,17-{ }^{3} \mathrm{H}$ oestradiol - 17B $\left({ }^{3} \mathrm{H}-\mathrm{E}_{2}\right)$, specific activity $137 \mathrm{Ci} /$ monol, was obtained from New England Muclear (Boston, LH.S.A.).

The radiochemical purity was initially greater than $99 \%$ and was checked regularly by thin layer chromatography. When necessary, the product pas purified by gel tiltration on Sephadex LH 20 (Pharmacia, Uppsala, Sweden).

2. Unlabelled oestradiol-17B ( $\left.\mathrm{E}_{2}\right)$ was purchased from Sigma Chemical Cotinany (U.S.A.

\section{B. Other chemicals}

All other chemicals used were commercial products of analytical grade.

\section{Reggents}

1. Tris-HCl buffer $10 \mathrm{mM}$, pH 7.5 at $20^{\circ} \mathrm{C}$, containing I mM EDTA, $3 \mathrm{~m} \mathrm{Nak}_{3}$ and $0.5 \mathrm{~mm}$ dithüothreitol (D)T).

2. Dextran-coated charcoal suspensions. The three dextran-coated charcoal suspensions used all contained dextran $0.5 \mathrm{~g} / \mathrm{l}$ (Dextran 70 , Pharmacia), gelatine $2 \mathrm{~g} / \mathrm{l}$ 
(Gelatine wej.ss, Merck), wa 11 as $1.25 \mathrm{~g} / 1,2.5 \mathrm{~g} / 1$ or $5.0 \mathrm{~g} / 1$ charcoal (Charcoli actiwated, decolorizing powder, BDH Chemicals latd) in the buffer sollution.

\section{Tissue collection and storage}

1. Human breagt tumours.

Tumour were excised, freed from fat as completely as possible, frozen in 1 iquid nitrogen and transported difrectly to the

laboratory where they were stored at $-95^{\circ}$ g prior to $x$ say.

The residual cytogols after the estimationis were pooled and frozen in such a way that a pool of ER + and a pool of ER-cytosols was obtained. These pools were used for further systematic investigation and have already been mentioned in the Introduction.

2. Healthy human breast tissue.

The tissue was obtained by plastic surgery and imediately after excision it wats placed on ice, dissected free of fat, sliced and rinced with sterile ice-cold $\mathrm{NaCl} 0.97$ solution and stored at $-95^{\circ} \mathrm{C}$.

Here, roo, residual cytosols were pooled for further systematic investigations.

3. Calf uterus.

a. The uteri of three-month-old calves were placed on ice ingediately after excision and transported to the laboratory were they were washed with sterille ice-cold NaCl $0.9 \%$ solution, sliced and stored at $-95^{\circ} \mathrm{C}$.

b. A part of these frozen uteri was crushed and lyophilised in a Christ lyophiliser. From the anhydrous tissue a powder was prepared in a Braun mixer at $4^{\circ} \mathrm{C}$. This tissue powder was used to prepare the "pool" cytosoll.

E. Preparation af homogenaces and cytosals.

Preparation of homogenates and cytosols was pexformed according to a slightly modified EORTC procedure, i.e. adding DTT to the extraction buffer to protect sulfhydryl groups in the receptor protein. The protein content of the cytosol was adjusted to 
approximately $6 \mathrm{~g} / 1$, where upon the deternination was repeated.

F. Protein determination

Protein determination was done by a biuret method in a centrifural analyser.

G. Incubation of cytosols with oestradiol

Cytosals $(200 \mu 1)$ were incubated for 22 hours at $4^{\circ} \mathrm{C}$ with $300 \mathrm{wl}$ of buffer containing increasing quantities, via. $0.15,0.30,0.60$ and 1.20 pmol ${ }^{3} \mathrm{H}-\mathrm{E}_{2}$, so that the final concentrations of ${ }^{3} \mathrm{H}-\mathrm{E}_{2}$ in the mediumere $0.3,0.6,1.2$ and $2.4 \mathrm{nM}$. A reference for radioactivity was prepared using buffer solution instead of eytosol.

H. Addition of coated charcoal

After the cytosol-tracer incubation, $0.5 \mathrm{ml}$ each of the three charconl suspensions was added to the incubated cytosol samples, mixed on a Vortex mixer, then incubated for various periodes from 5 to $45 \mathrm{~min}$ at: $4^{\circ} \mathrm{C}$; charcoal comcentrations in the media of viz. $0.625 \mathrm{~g} / 1,1.25 \mathrm{~g} / 1$ or $2.50 \mathrm{~g} / 1$ are thus obtained. Afterwards the tubes were centrifuged and $0.5 \mathrm{ml}$ of the supernatant was thaken for radioactivity measurement (liquid scintillation). The radioactivity measured was corrected for blank values. The ratio of bound to free radicactivity and the amount: of radioactivity bound per milligram protein was then calculated for each charcoal concentration used and for incresing concentrations of ${ }^{3} \mathrm{H}-\mathrm{E}_{2}$ tracer in the reaction medium. The influence of incubation time with constant quantities of charcoal could also be calculated. It must be kept in mind that at this point no distinction was made between specific and non-specific binding of tracer. This could, however, be calculated from the Scatchard plots obtained ( 5 ).

RESULTS

Influence of warying amounts of charcoal on the amount of tracer bound in cytosols with high receptor activity and on the apparent affinity constants $k_{a}$ for the binding reaction. 


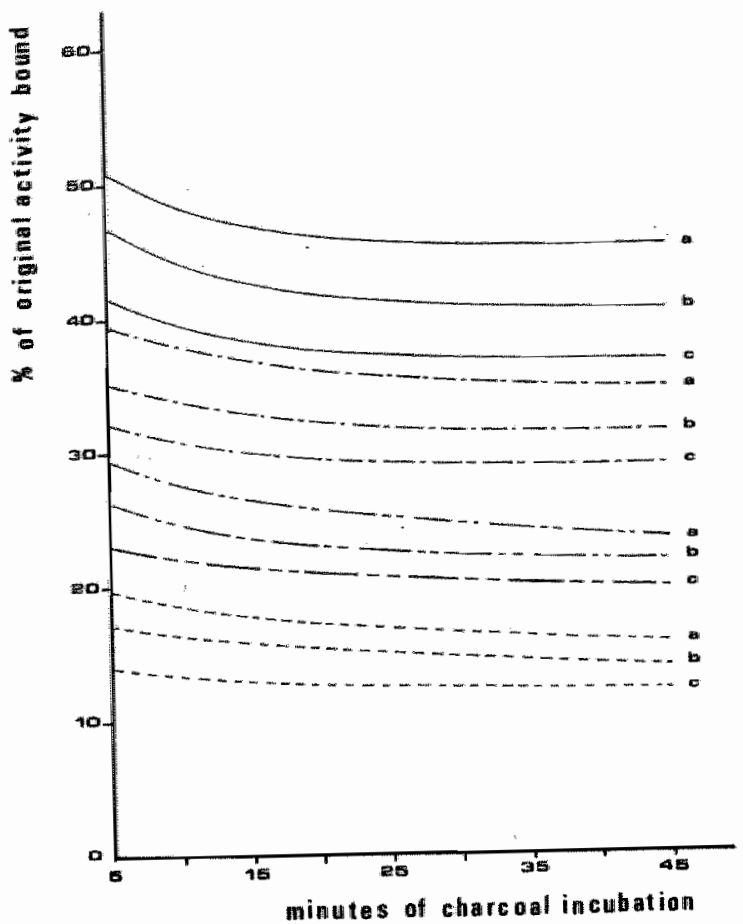

Liguare $2-1$

Binaing of tracen th ER + cytosals. Effeot of codted charcoat incubation time. Charcoat concentrations in the incubation medium a: $0.625 \mathrm{~g} / \mathrm{t}$, b: $1.25 \mathrm{~g} / \mathrm{t}$, c: $2.50 \mathrm{~g} / \mathrm{t}$. ${ }^{3} \mathrm{H}-\mathrm{F}_{2}$ concentrations: $0.3 \mathrm{nH},-\cdots 0.6 \mathrm{nH},-\ldots-1.2 \mathrm{~mm}, \ldots-3.4 \mathrm{~m}$.

These cytosols were prepared fron calf uterus and ER + thuman breast tumours as mentioned in the Introduction (classes $a, b, c$ and $d$ ).

for each sample, the proportion of the added anount of $3 \mathrm{E}-\mathrm{H}_{2}$ bound to bhe cytasol receptar protein was calculated. This was done with the chree different amounts of coated charcoall used for 
adsorption of the free tracer in the reaction medium. These experiments were also performed with increasing times af incubation, 5 to $45 \mathrm{~min}$, with the coated charcos.l.

The results of these experiments are given together in figure $2-H$. It is elear that the apparent binding percentage of ${ }^{3} \mathrm{E}-\mathrm{H}_{2}$, to the receptor protein decreased when increasing amounts of coated charcoal were used. This appears to be true for media containing different concentrations of tracer, without exception. As could be expected the binding percentage was lower when the tracer concentration was increased.

Next it can be seen that the binding percentage appeared to decrease with prolonged incubation time. After about 10 to 15 min of incubation with coated charcoal a state of equilibrium was more or less reached.

$\tan 2 e^{2}-1$

Affinity constants $\mathbb{K}_{\mathrm{a}}$ (a protein/mol) caloulated by sactehard plota. whe given values are to be miluplied by $10^{\circ}$.

\begin{tabular}{|c|r|r|r|r|r|r|}
\hline \multirow{2}{*}{$\begin{array}{c}\text { imcubation } \\
\text { time }\end{array}$} & \multicolumn{3}{|c|}{ pool ER+ tumours } & \multicolumn{3}{c|}{ pool calf uterus } \\
\cline { 2 - 7 } & \multicolumn{3}{|c|}{ charcoal concentrations in the medium $(g / 1)$} \\
\cline { 2 - 7 } & 2.50 & 1.25 & 0.625 & 2.50 & 1.25 & 0.625 \\
\hline 5 & 19.7 & 10.7 & 8.2 & 25.8 & 15.9 & 10.1 \\
10 & 19.9 & 17.9 & 11.2 & 25.1 & 23.5 & 14.5 \\
15 & 21.3 & 17.2 & 11.6 & 19.9 & 20.5 & 14.9 \\
20 & 23.8 & 20.6 & 14.6 & 19.3 & 22.8 & 16.3 \\
25 & 24.6 & 20.4 & 14.0 & - & $\ldots$ & \\
30 & 21.7 & 19.1 & 16.0 & 19.8 & 24.6 & 22.0 \\
35 & 21.2 & 19.1 & 16.7 & 19.2 & 22.1 & 21.5 \\
40 & 20.7 & 22.1 & 18.1 & 18.4 & 22.1 & 22.5 \\
45 & 20.2 & 21.2 & 19.1 & 17.1 & 20.1 & 21.0 \\
\hline
\end{tabular}




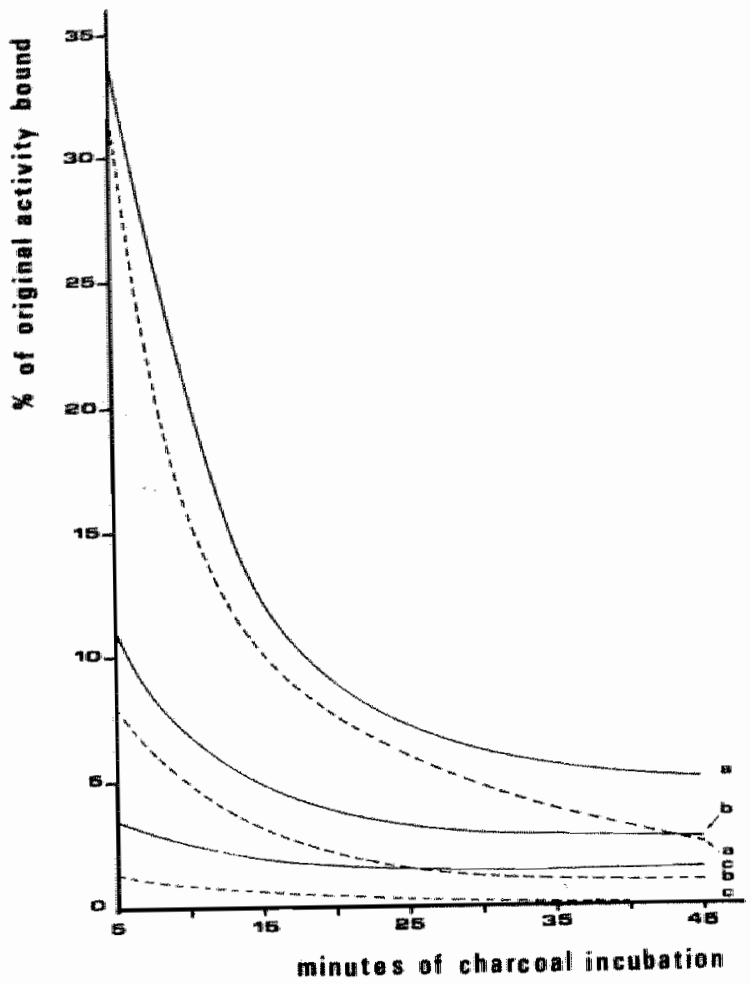

rigure $2-2$

Binding of tracer in healthy breast tissue cytosols. Effect of coated charcoat incubation time. Charcoat aroentrations in the imoubation medium a: $0.625 \mathrm{~g} / \mathrm{z}_{\mathrm{j}}$ b: $1.25 \mathrm{~g} / \mathrm{t}, \mathrm{c}: 2.50 \mathrm{~g} / \mathrm{t} .{ }^{3} \mathrm{H}-\mathrm{E}_{2}$ concentrationa: $0.3 n A, \ldots \ldots-5.5 \%$.

Similar results were obtained for cytosols either from calf uterus and from $\mathrm{ER}+$ humam breast cumours. Apparent affinity constants are given in table $2-7$.

Influence of varying amounts of charcoal on the amount of tracer 


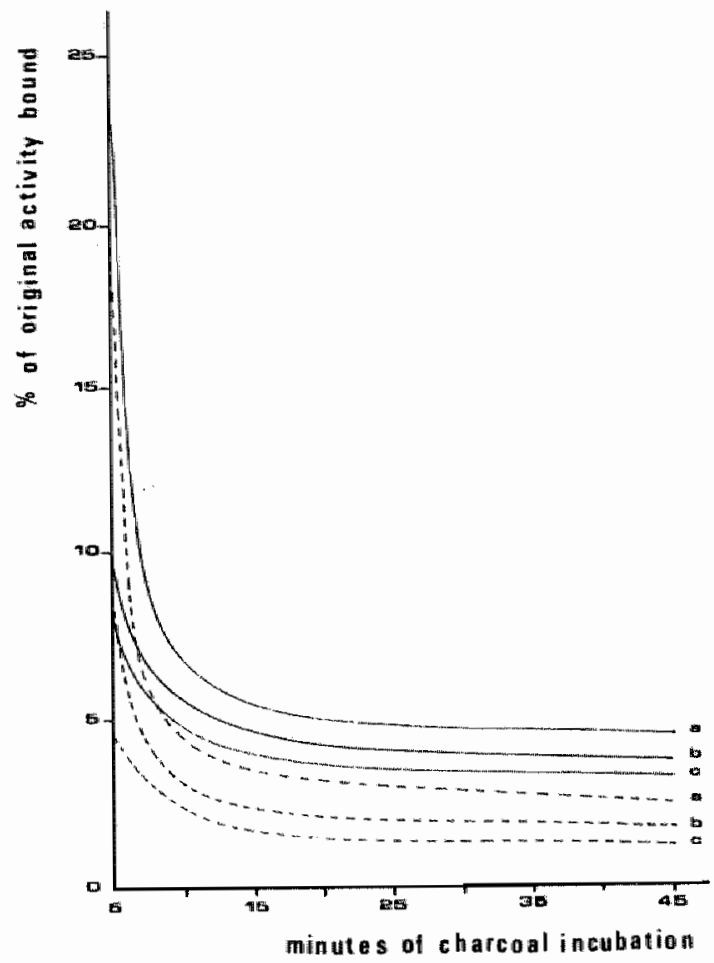

figure

Bending a thaer in ER- aytosols. Effect of coated charcoat

incubaton time. Charcal conoeritrations in the incubation mediam a: $0.625, \alpha / 2, b: 7.25 g / 2, c: 2.50$ o/2. ${ }^{3} \mathrm{E}-\mathrm{H}_{2}$ concentations:

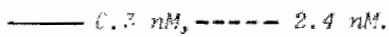

bound in cytosols with low and negat ive receptor actiwity.

These cytosols were prepared from either healthy human glandular breast tissue (class e) or receptor negative human mamary cancers (class f). The same investigations were performed as with the 
vestrogen receptor postitive cytosols. Results are given in fingure $2-2$ and pigure $z-z$.

Binding of ${ }^{3} \mathrm{p}-\mathrm{p}_{2}$ to the coated charcaol again increased with incressing atmount of the latter whith prolonged incubation time. However, an apparent equilibrium ras reached after prolonged incubation with coated charcoal, i.e. about 20 - 35 minutes, cytosol from healthy glandular breast tissue taking longer to reach equilibrium.

The calculation of affinity constants gives no reliable values on account of very low amounts of tracer bound in the cytosols.

\section{DISCUSSION}

From these results the following conclusions can be made:

1. The amount of coated charcoal used for the separation of free tracer from receptor bound tracer apparently influences the result. This can only be explained by either an exchange of bound tracer between receptor protein and coated charcoal or by the binding of more than only free tracer to the charcoal. In this case we suppose that a certain amount of tracer-receptor complex is bound to the charcoal. This means that the coated charcoal has an awidity both for the smaller molecules ${ }^{3} \mathrm{H}-\mathrm{E}_{2}$ and to g lesser extent for the receptor protein, the latter now be hing marked by ${ }^{3} \mathrm{H}-\mathrm{E}_{2}$.

2. There is a clear difference between the binding rates of $3 \mathrm{~F}_{2}-\mathbb{H}_{2}$ to protein in the $\mathrm{ER}$ * cytosols from calf uterus and receptor positive tumourg, and those found in ER-tunours and low $\mathrm{RR}$ activity manuary gland tissue.

With the latcer cytosols an equilibrium is reactied after a significanty longer period of incubation with coated charcoal. It mipht be concluded from these data that the binding of ${ }^{3} E-H_{2}$ co ER + tumour cytosol or equally ER + calf uterus cytosol is stronger than with cytosols from receptor poor tissues. This is 
in accordance with the walues for $k_{a}$ found when Scatchard analys is is applied to the results of the detemintion.

The apparent values found for the affinity constancs as given in tobte 2-1 do support the hypothes is that the receptor protein oestrogen complex is adsorbed to the coated charcoal. It appears that this process is more rapid in the presence of the higher charcoal concentrations. The result of the said adsorption is that diminished values for "bound" tracer are found after longer periods of incubation so that the apparent affinity constants are decreased.

It is to be concluded that the use of coated charcoal is anly permitted under strictly standardised experimental conditions, otherwise inevitably it leads to erroneous results.

\section{REFERENCES}

1. Ratcliffe, J.G. (1974) Separation techiques in saturation analysis. Br. Med. Bull, 30,32-37

2. Herbert, V., Lau, K.S., Gottlieb, O.W. and Bleicher, S.J. (1965) Coated charcoal immunoassay of insulin. J. Clin. Endocrinol. 25, $1375-1384$

3. E.O.R.T.C. Breast Gancer Cooperatiue Group (1973) standards for the assessment of eatrogen receptors in human breast cancer. Eur. J. Cancer $9,379-381$

4. E.O.R.T.C. Breast Cafcer Cooperative Group (1981) Standards for the assessment of hormone-sensitivity in humam breast cancer. Report of the second workshop on March 16/17, 1979, at the Antoni van Leeuwenhoek-Huis, Amsterdam (To be publitiblyed)

5. Scatchard, G. (1949) The attractions of proteins for anall molecules and ions. Ann. New York Acadi. Sci. 51, 660-672 
chaptar 3

COATING OF CHARCOAL BM DEXTRAN

Published in NucCompact (1980) 11, $162-167$ by

Ph.G.F.A.H. Ralet, P.J. Brombacher and A.H.J. Gijzen.

SUAHATYY

With the airn of assessing the influence of the properties of the different constituents of a dextran coated charcoal suspension on the separation of bound from free tracer in the oestrogen receptor determination, we have studied the distribution of molecular weights constituting one dextran preparation ( $T-70$ of Pharmacia). The influence exerted by the method of pretreatment of the charcad used for the dextran coating has also been quantitatively and quallitatively investigated. It appears that for optimal coating with dextran the charcoal must be kept in vacuo prior to the coating procedure. The latter requires at least three hours incubation time. The lower molecular weight fraction in the dextran T-70 preparation is preferentially adsorbed.

\section{INTRODUCTION}

Dextran coated charcoal is ofter used in immunoasays for the separation of bound from free tracer $(1,2)$. Dur inveligation on the determination of oestrogen receptor protein in cytosols led us to investigate the nature of the coating of dextran coated charcoal. Several aspects of this procedure have to be considiered, e.g. the 
homogeneity of the dextran, the nature of the charcoal uged in the procedures and the incubation time required for coating. It can be imagined that the factor influence the coating of the charcoal used with the selected dextran preparation.

Wow the nature of the coated charcoal certainly thas an influence on the separation of free from bound oestrogen in the receptor determination and perthaps a greater influetce on the binding of owtrogen receptor complex to the coated charcoal. The latter, of courge, should not happen but we have proved ( 3 ) that a certain amount of protein bound oestrogen is caught by the dextran coaced charcoal preparations recomended genterally $(4)$. We have thus studied the mentioned aspects of the coating procediure.

A main motive too for our study was the unsatisfactory result of an interlaboratory investigation on the quality control of oestrogen receptor assays in human breast cancer $(5)$. The different possible causes of the lack of agreement in the result from analyses in several laboratories necessarily need further study beyond the present contribution on the mature of the dextran coated charcoal.

\section{MATERIALS}

\section{Chemicals}

- Dextran T-70 (Pharmacia, lot 11073).

- Charcoal activated, decolorizing powder, BDH. Lta., lot 6561070.

Quantities of this charcoal were respectively:

". stored 80 hours under wacum ("vacuum charcoal")

2. exposed 80 hours as thin layer on filter paper in the air at roon temperature ("air charcoal")

3. saturaced with $\mathrm{CO}_{2}$ for 80 hours in an Erlenmeyer flask, shaken periodically (" $\mathrm{CO}_{2}$-chareoal").

- sephadex $6-100$ and $6-200$, Sephacryl $\mathrm{f}-300$ (Pharmacia).

- Low and high molecular weight gel filtration calibration kits (Pharnacia). 
- All other chemicals used were commercial products of analytical grade.

\section{Reagents}

- Tris-HCl buffer $10 \mathrm{mM}$, $\mathrm{pH}^{\mathrm{H}} 7.5$ at $23^{\circ} \mathrm{C}$, containiag 1 m EDTA, $3 \mathrm{mM}$ $\mathrm{NaN}_{3}$ and $0.5 \mathrm{mM}$ dithiothreitol (TED buffer).

This buffer is also used for determination of aescragen receptors.

- The dextran charcoal suspensions used contained $0.5 \mathrm{mg} / \mathrm{ml}$ of dextran $\mathrm{T}-70$ and either 0.5 or $2.5 \mathrm{mg} / \mathrm{mI}$ of charcoal. The contact between the dextran solutions and the different quantities of the three different charcoals was set at 3 hours, (vide infra) at $23^{\circ} \mathrm{C}$ with constant stirring. Each suspension was then centrifuged and aliquots of the supernatant assayed for dextran content or used for gel filtration.

Equipment for Gel Filtration

$-2 \mathrm{~cm}^{2} \times 100 \mathrm{~cm}$ columr (Pharmacia K $16 / 100$ ).

- Peristaltic pump Minipuls II (Gilson).

- Spectrochrom M photometric detector (Gilson).

- Fraction collector MTDC (Gilson).

- Recorder BDC, input $10 \mathrm{mV}$ (Kipp \& tonen).

\section{METHODS}

Dextran Adsorption vs. Incubation Time:

The incubation time required for optimal coating of charcoal with dextran was investigated as follows:

Several charcoal samples were placed in Erlenmeyer flaks and adequate volumes of dextran solution in TED buffer $(0.5 \mathrm{mg} / \mathrm{m} 1)$ were added. The contents of the flasks were constanty stirred (magnetic stirrer) at $23^{\circ} \mathrm{C}$. At several predetermined times samples were removed and immediately centrifuged to separate charcoal from the supermactint liquid. In the latter dextran concentrations were determined by the anthrone method (see dextran assay). The pexcentage of dextran 
adsorbed to the charcoal was then calculated.

Dextran Assay

We used the method described by T.A. Scott and E.H. MeIvin (6) whth sone modifications: 1 mI of each dextran sample was cautiously pipetted into a glass tube $(100 \times 12.5 \mathrm{~mm})$ containing $5 \mathrm{ml}$ of the anthrone reagent (200 mg anthrone dissolved in 100 mil sulfuric acid 35\%) and itmersed in an ice bath. The tubes were then stoppered, inverted ten tindes and immediately placed in a shaking waterbath att $90^{\circ} \mathrm{C}$ for 12 minutes (we found a sitable maxintall absorption after 12 minutes reaction at this temperature).

The tabes were then inmediately cooled in the ice bath and the absorbances were quickly read in $1 \mathrm{~cm}$ cells at $620 \mathrm{~nm}$, Using TED buffer as reference.

For the deternination of the dextran content in the fractions from the gel filtration used standards containing $0.01,0.02,0.03$, $0.04,0.05,0.07,0.1,0.2$ and $0.3 \mathrm{mg}$ dextran $\mathrm{T}-70 / \mathrm{ml}$ TED buffer. For the other determinations: $0.1,0.2,0.3,0.4,0.45$ and $0.5 \mathrm{mg}$ dextran $T-70 / \mathrm{mi}$ TED buffer.

\section{Gel Eiltrations}

a. On Sepliadex ${ }^{R}$ G-100/6-200

Colum: $K 16 / 100$ with flow adaptors.

Bed dimensions: $2 \mathrm{~cm}^{2} \times 90.5 \mathrm{~cm}$.

Ge 1: Sephadex ${ }^{R} G-100$ and Sephadex ${ }^{R} G-200$ in the proportion (weight) $2: 1$ (as decribed in reference 7 ).

Eluent: TED buffer (see reagents).

Gel filtrations: upward flow, performed at $23^{\circ} \mathrm{C}$.

Sample wolume for each run: $2.0 \mathrm{~m} 1$.

Fllow rate: $4.35 \mathrm{mil} \cdot \mathrm{can}^{-2} \cdot \mathrm{h}^{-1}$.

Fraction wolume: 125 arops $\simeq 2.0$ ral

The peak lewels of blue dextran 2000 and the calibration proteins were detected spectrophotometrically (A. 254 man); the peaks of glucose and dextran were measured spectrophotometrically at 620 nm atcer the anthrone reaction. 
Procedure:

\begin{tabular}{|c|c|c|}
\hline Run & Sample & Concentrations \\
\hline lst & $\begin{array}{l}\text { Blue dextran } 2000 \\
\text { Glucase }\end{array}$ & $\begin{array}{l}0.5 \mathrm{mg} / \mathrm{ml} \text { buffer } \\
0.5 \mathrm{mg} / \text { m } 1 \text { buffer }\end{array}$ \\
\hline $2 n d$ & Dextran $T-70$ & 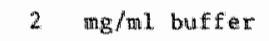 \\
\hline $3 \mathrm{rd}$ & $\begin{array}{l}\text { Catalase } \\
\text { Albumin }\end{array}$ & $\begin{array}{lll}3 & \mathrm{mg} / \mathrm{ml} \text { buffer } \\
7 & \mathrm{mg} / \mathrm{ml} \text { buffer }\end{array}$ \\
\hline $4 \mathrm{th}$ & $\begin{array}{l}\text { Ferritin } \\
\text { Aldolase } \\
\text { Ovalburain } \\
\text { Ribonuclease }\end{array}$ & $\begin{array}{rrr}0.5 & \mathrm{mg} / \mathrm{ml} & \text { buffer } \\
2 & \mathrm{mg} / \mathrm{ml} & \text { buffer } \\
7 & \mathrm{mg} / \mathrm{ml} & \text { buffer } \\
10 & \mathrm{mg} / \mathrm{ml} & \text { buffer }\end{array}$ \\
\hline Sth & Dextran $T-70$ & $0.5 \mathrm{mg} / \mathrm{ml}$ buffer \\
\hline 6th & $\begin{array}{l}\text { Solution of dextran } \mathrm{T}-70 \\
\text { Agitated for } 3 \text { hours at } 20^{\circ} \mathrm{C} \text { with } \\
0.5 \mathrm{mg} / \mathrm{ml} \text { of vacuum stored charcoal }\end{array}$ & $(0.5 \mathrm{mg} / \mathrm{ml}$ buffer $)$ \\
\hline 7 th & $\begin{array}{l}\text { Solution of dextran } \mathrm{T}-70 \\
\mathrm{Ag} \text { itated for } 3 \text { hours at } 20^{\circ} \mathrm{C} \text { with } \\
0.5 \mathrm{mg} / \mathrm{ml} \text { of } \mathrm{CO}_{2} \text { saturated charcoal }\end{array}$ & (0.5 $\mathrm{mg} / \mathrm{ml}$ buffer) \\
\hline $8 \mathrm{ch}$ & $\begin{array}{l}\text { Bue dextran } 2000 \\
\text { Glucose }\end{array}$ & $\begin{array}{l}0.5 \mathrm{mg} / \mathrm{ml} \text { buffer } \\
0.5 \mathrm{mg} / \mathrm{mll} \text { buffer }\end{array}$ \\
\hline
\end{tabular}

b. On Sephacryl ${ }^{R}$ s-300

Same procedure as with the Sephadex ${ }^{R}$ G-100/G-200 mixture (except

that the gel filtration was descending and the fllow rate was

$\left.7.25 \mathrm{mil}^{-1} \cdot \mathrm{cm}^{-2} \cdot \mathrm{m}^{-1}\right)$

\section{RESULTS AND DISCUSSION}

Adsorption of Dextran vis Incubation Tire

In figure $3-1$ the rate of adscrption of dextran to several charcol samples is given. 


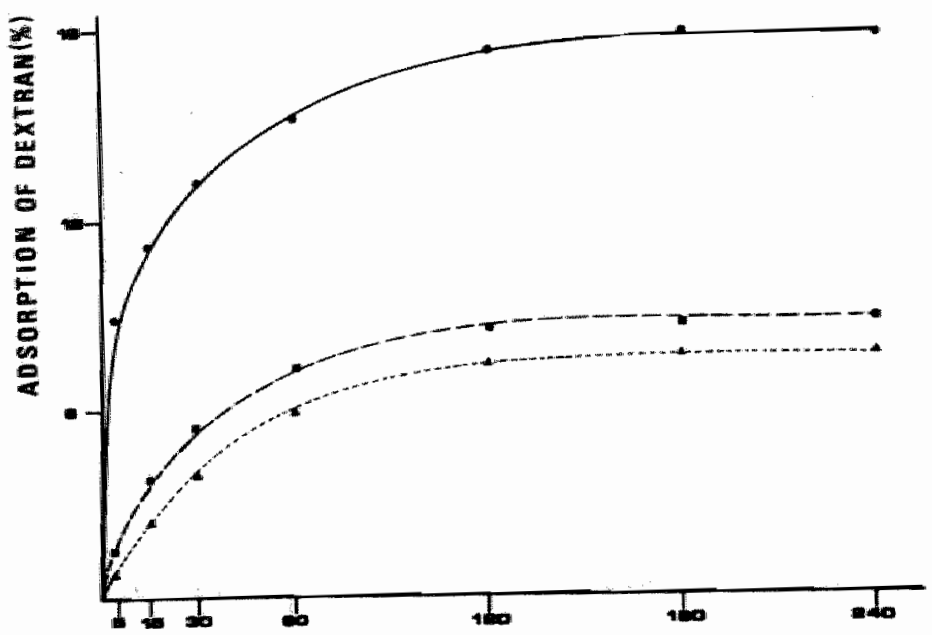

figure $3-2$

INCUBATION TIME $($ min $)$

Infuence of thabation time on adsorption of dextron to oharooal. The percentage of dextran adsorbed from the solution to eharead is given as a funotion of incubation time (sea text) for sevenat chamat amples being stored vis. in vacuo - - in air - or in a axbon dioxide atmosphere - - - Dextron concentration befame incubation $0.5 \mathrm{mg} / \mathrm{mi}$. Charcoat added $2.5 \mathrm{mg} / \mathrm{ml}$ in the finat volume.

It is clear that the charcoal coating procedure must be continued for at least 3 hours in order to reach a state of saturation. As could be expected the in vacuo stored charcoal bound the highest atmount of dextran. Here again it is clear that especially carbon dioxide but air as well considerably diminist the binding capacity of charcoal towards dextran. Moreover, it is not improbable that the sometintes found poor reproducibility in the detiemination of oestrogen receptor is also due to the use or improper preparations of dextran coated charcoal. This certainly explains to some extent 
the unwanted adsorption of receptor bound bestrogen which we found in sone experiments ( 3 ).

\section{Homogeneity of Dextran $\mathrm{T}-70$}

Contrary to some other dextrans (?) the dextran T-70 used in this study gave only a single peak by gel filtration on Senhadex $G^{-100 /}$ $\mathrm{G}-200(2: 1)(f i g u r e 3-2)$ with $\mathrm{K}_{\mathrm{av}}=0.091$ (figure $\left.3-3\right)$. A similar peak was obtained using Sephacry ${ }^{R} \mathrm{~s}-300$.

\section{figure $3-2$}

Gelfiltration of dextman $T-70$.

Bed dimenstions: 2 ant $^{2} \times 90.5 \mathrm{~cm}$; get: Sephadew G-100 and $G-200$ in the proportion 2: 1; elwent. TED buffer Tras-BCt buffer $10 \mathrm{ml}$, PH 7.5 at $23^{\circ} \mathrm{C}$, containing $1 \mathrm{mM} \mathrm{EDTA}, 3 \mathrm{kM}$ WaN 3 and $0.5 \mathrm{mM}$ dithiothreitol); get apward flow; sample 2.0 mi of dextran $7-70$ $12 \mathrm{mg} / \mathrm{ml}$ TED bufferl; flow rate: $4.35 \mathrm{~mL} \cdot \mathrm{cm}^{-2} \mathrm{~h}^{-1}$; praction volume: 125 drops $=2.0 \mathrm{mi}$.

Calibration peake: blue dextran 2000 (A); fermotim ( B); catalase (C); aldolase (D); albumin (E); owatbumin (F); onymotropoinogen A (G), ribonwolecase A (H); glucose (I).
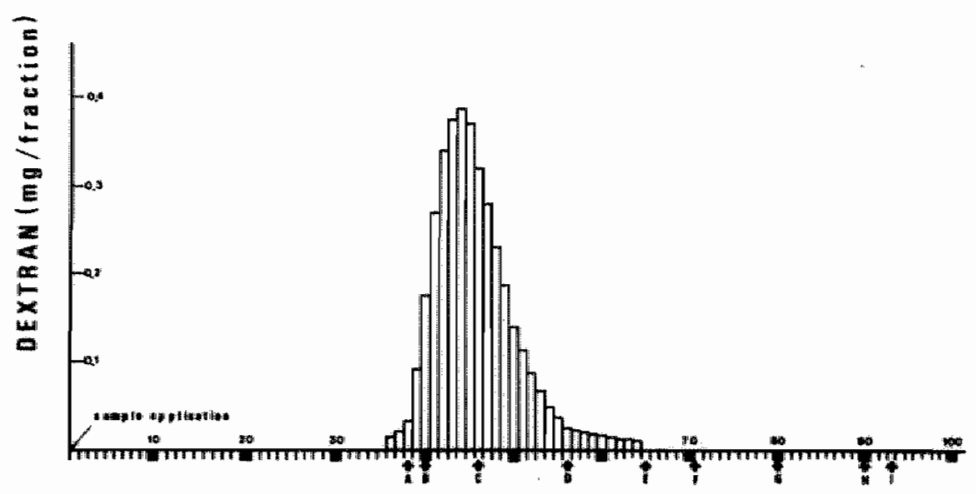

F RACTION NUMBERS 


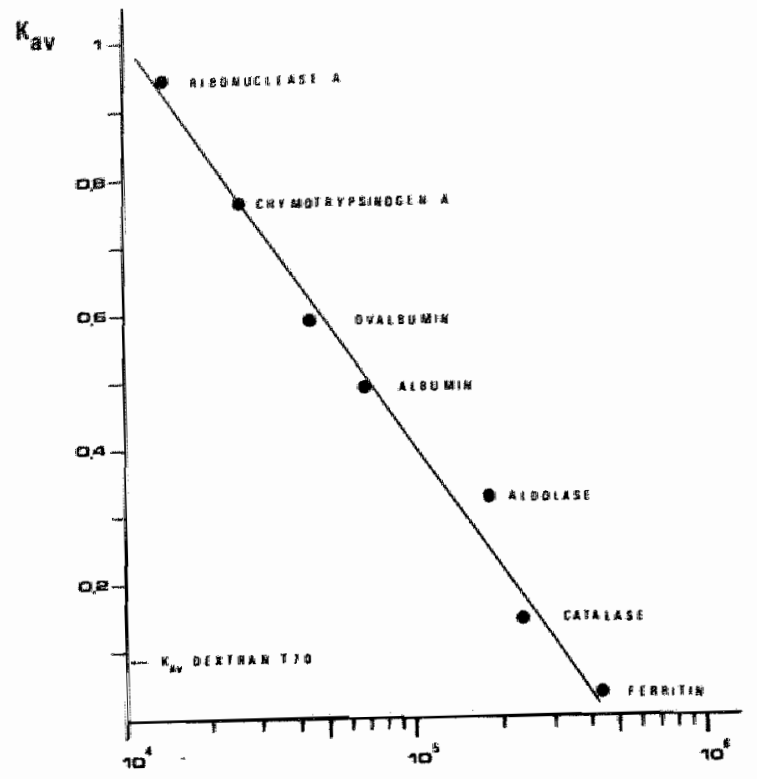

MOLECULAR WEIGHT

figure $3-3$

Calibration dume using calibration proteins on sephadex G-100 G-g00 (2: 1). Gel fiztration conditions see fighre $3-1$.

According to the manufactors' documentation the we ight average molecular weight $\bar{M}_{\mathrm{W}}$ is approximatively 70,300 and the number average molecular weight $\overline{\mathrm{m}}$, 36,000 .

Although a single meak was found the molecular weight declared for the dextran $(70,000)$ cannot be directly deducted from the calibration of the colunn. "This is due to the fact that protein gel Eilcration is not simply comparable to polysaccharide gel filtration for which no calibrators were awallable. Wevertheless, colum calibration is anyhow necessary to control and check the homogeneity 
of the gel and the constancy of colum properties.

Wature of Charcoal Used in the Determination of Destrogen Receptors

It was described earlier ( 8$)$ that charcoal pretreated either with $\mathrm{CO}_{2}$ or just prepared by boiling in water was highly different as far as adsorptive properties and capacities are concerned. For example, the adsorption of vitamin $B_{12}$ could not be performed when charcoal was saturated beforehand with carbon dioxide. For this reason we compared charcoal treated in wacuo for 80 hours, charcoal saturated with $\mathrm{CO}_{2}$ for the sane period of time and charcoal kept in air for this time. It appeared that the adsorptive capacity of the charcoal kept in carbon dioxide was much less than that of the charcoal kept in vacuo, but only slightly less than that of the charcoal exposed to air. This suggests that active charcoal really has to be evacuated before using it for the preparation of dextran coated charcoal for radioimunoassay and similar experiments. The results of our investigarions are given in figure $3-l$. We started from the two concentrations of charcaal which were used by the E.O.R.T.C. members $(0.5$ and $1.5 \mathrm{mg} / \mathrm{ml})(5)$.

It appeared that to the $0.5 \mathrm{mg} / \mathrm{m} 1$ of charcoal kept in $\mathrm{CO}_{2}$ or in vacuun respectively $1 \%$ and $2.8 \%$ of the dextran was bound whereas, in contrast, the $2.5 \mathrm{mg} / \mathrm{ml}$ of charcoal kept in vacuo was able to bind $17.6 \%$ of the dextran present in the solution. This was much more than the $7.6 \%$ of dextran which was adsorbed from the solution by the $\mathrm{CO}_{2}$ saturated charcoal. Similar considerations apply to the comparison of charcoal kept in air with charcogl kept under vacum (table $3-8)$.

From tabte $3-1$ and tabte $3-2$ it can be concluded that a charcoal kept under carbon dioxide is even less than charcoal kept in air, although the difference is not great (see also figure $3-1$ ).

\section{Adsorption of Dextran to Charcoal}

If we look upon the mature of the dextran fractions adsorbed to charcoal we obtaim the results of sephadex gel filtrations ans given 


\section{toble $3-1$}

Destran content (migh); rematning in the solution after adsomption

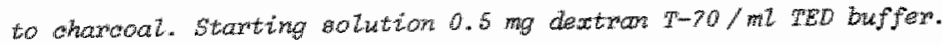

\begin{tabular}{|c|c|c|}
\hline charcoal & vacuum treated & $\mathrm{CO}_{2}$ treated \\
\hline $0.5 \mathrm{mg} / \mathrm{ml}$ & 0.486 & 0.495 \\
$2.5 \mathrm{mg} / \mathrm{mi}$ & 0.412 & 0.462 \\
\hline
\end{tabular}

table $3-2$

Dextran content (mginl); memaining in the aolution after adaorption to charcoal. Starting solution $0.5 \mathrm{mg}$ dextran 1 -70/mt ate buffex.

\begin{tabular}{|l|c|c|}
\hline charcoal & vacuum treated & air treated \\
\hline $0.5 \mathrm{mg} / \mathrm{ml}$ & 0.483 & 0.491 \\
$2.5 \mathrm{mgg} / \mathrm{mL}$ & 0.410 & 0.457 \\
\hline
\end{tabular}

in figure 3 - 4 . Very similar results were obtained by gel filtration on Sephacryl ${ }^{R}$ s-300. It appears from this figure that the "heavier fractions" of the dextran are not adsorbed under the conditions of the experiment whereas the "lower molecular weight fractions" of the dextran are acisorbed to the charcoal.

As expected, the amount of low molecular dextran adsorbed to the charcoal was highly dependent on the nature of the pretreatment of the charcoal used, eug. either incubation in carbon dioxide, in air or in vacuo.

It appeared that the adsorption of the lower molecular weight: fractions took place pteferentially to that of the larger macromoleculles of dextran. Practically none of the later was andsorbed using various charcoal. 


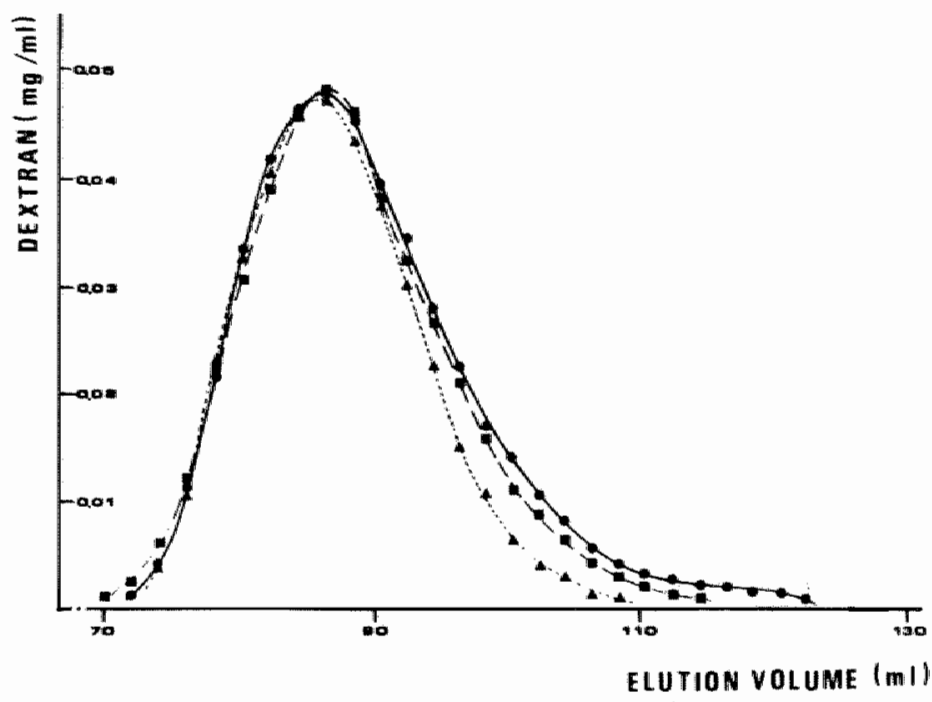

fitgure $3-4$

Get filtration on Sephadex ${ }^{R}$ G-100/G-200 (2: 1 ).

Get filtration sonditions see figure $3-1$.

$\longrightarrow$ dextron $T-70 \quad 0.50 \mathrm{mg} / \mathrm{mil}$ TED buffer

- - - dextran $\mathrm{r}-70 \quad 0.50 \mathrm{mg} / \mathrm{mL}$ TED buffer after action of $2.5 \mathrm{mg} / \mathrm{ml}$ of $\mathrm{CO}_{2}$ ehareoal"

-A-4- deatrap T-70 $0.50 \mathrm{mg} / \mathrm{mL}$ TED buffer after action of $2.5 \mathrm{mg} / \mathrm{mL}$ of "wacum chareoat"

From the experiments presented here, it can be concluded that the preparation of dextran coated charcoal must be necesiarily done in a highly reproducible way in order to compare results of experiments on one day whth those on an other and to compare one preparation with an other.

Furthermore, the dextram coated charcoall is mainly coated by "Iight dextran fractions". Whether this is of influence on the specificity 
for adsorption of proteins and for smaller molecules cannot be stated at this moment.

\section{CONCLUSIDN}

The high variatility found in comparing the results of determinations of oestrogen receptor proteins in cytasols both between seriem in the same laboratory and between different laboratories is probably to some extent due to the nature of the used dextran coated charcoal preparation. From the present study it appears that the coating of charcoal with dextran must be done under highly standardiced conditions in order to obtain reproducible preparations. The latter are a conditio sine qua non in the difficult field of inwertigation of receptor protieing where so many known and perhaps hirtherto unknown factors do influence the outcome of the analysis.

\section{REFERENCES}

I. Herbert, V., Lau, K.S., Gottlieb, C.W. and Bleicher, S.J. (1965) coated charcoal immunoasay of insulin. J. Clin. Endocrinol. 25, $1375-1384$

2. Ratcliffe, J.G. (1974) Separation techniques in saturation analys is. Br. Med. Bu11. 30, 32-37

3. Ralet, Ph.G.F.A.H. and Brombacher, P.J. (1981) The use of coated charcoal in the determination of oestrogen receptor activity. Eur. J. Nucl. Med.

4. E.0.R.T.C. Breast Cancer Cooperative Group (1973) Standards for the assessnent of estrogen receptors in human bresst cancer.. Eur. J. Cancer 9, 379-381

5. Koenders; A. and Benrad, Th. (1980) Rwaliteitscontrole van hormeonteceptor metingen. Tijdschr. Ned. Ver. K1in. Chemie 6, $185-186$ 
6. Scott, T.A. and MeIvin, E.H. (1953) Determination of dextran with anthrone." Anal. Chem. 25, 1656-1661

7. Van Nispen tot Pamerden, E.B.L.M. (1974) Dextran, onderzoek natar kwaliteit voor klinisch gebruik. Mededelingen van de Nederlandse Vereniging voor Ziekenhuisapothekers $30,85-110$ 
chapters

\author{
OESTROGEN RECEPTOR DETERMINATION \\ AFTER PROTAMINE SULPHATE PRECIPITATION
}

\title{
SUMMARY
}

The determination of cytasol destrogen receptor proteins has been investigated after precipitation with protanine sulphate. No satisfactory results could be obtained on account of continuing loss of radioactivity in the necessary washing procedures. Substitution of the generally recomended dextran coated charcoal (DCC) routine procedure for the determination of oestrogen receptors by a protamine sulphate method could not be advised.

\section{INTRODUCTION}

For the determination of oestrogen receptor concentration in cytosols or nuclear fractions of target tissues a great variety of methods has been published. Difficulties generally encountered included the risk of losing specific oestrogen binding protein during the procedure. Incorrectly elevated results could be found due to imperfect separation between free and protein bound tracer (radiactively labell led oestronen).

The application of the so called DCC method (separation of free from protein bound tracer by dextran coated charcoal adsorption) is often recomended ( 1 ). However, excessively low values have been reported on account of receptor loss by charcosl adsorption ( 2 ). Another procedure has been published using gass beads for the adsorption of 
proteins including steroid-receptor complexes ( 3 ). Low receptor wallew were found, possibly due to the unsatisfactory adsorptive properties of the bead. It appeared that only $8 \mathrm{~S}$ proteins were adsarbed onto the glass. Specific oestragen receptor proteins, however, are also found in the 45 class proteins $(4,5)$.

Procedures avoiding adsorption techniques for the separation of free from bound tracer have also been published. Amongst these, sucrose denitity gradient centrifugation $(B)$, gel filtration ( 7 ) and agar gel electrophoresis (8) are mentioned. Apart from problems arising from the possibility of denaturation of proteins with these methods, these techniques are not suitable for the rapid analys is of large series of samples on a rovtine basis.

Another approach is the isolation of receptor proteins by the precipitation with polycation compounds, e.g. protamine sulphate. According to some authors (9) only specific oestrogen binding receptor proteins both in the $8 S$ and 45 classes are precipitated, leaving in solution the proteins that nom-specifically bind oestrogens and proteins from other than tharget tissues. It has also been clained that hormone-receptor complexes can be distinguished from free receptor proteins by selective precipitation at different temperatures $(10)$. Moreover, precipitation methods using pratamine sulphate appear elegant and easy to perform.

In this study the methods published by chamess (20) and by Robel and coworkers (11) were both investigated. Slight modifications were introduced where necessary for smooth routine procedures. Both methods are based on the same principle, i.e. precipitation of oestrogen receptar proteins with protamine sulphate.

In the Irst procedure (10) the precipitate is "coated" onto the wall of the reggent tube by centrifugation, whereupon incubation of the precipitate with radioactive oestradiol was perforned. After the disposd of excess tracer the radioactivity in the tubes was measured being an indication of the amount of oestradiol binding protein. 
In the second procedure (11) the precipitate was isolded by filtration onto a glass fiber filter. The precipitate containing receptar protein was incubated on the filter with tracer. Excess tracer was easily removed by rapid suction of washing buffer through the filter. Rapid washing was reported to be an advantage awoiding the dissolution of protein with bound radioactivity and loss of receptor bound tracer in the washing procedure.

\section{CHEMICALS}

$-2,4,6,7,16,17-{ }^{3} \mathrm{H}$ oestradiol-173: $\left({ }^{3} \mathrm{H}-\mathrm{E}_{2}\right)$ specifuc actiwity $137 \mathrm{ci} /$ monol (New England Nuclear)

- 160-125 I-3,17B-oestradiol $;\left(125 \mathrm{~T}-\mathrm{E}_{2}\right)$ specific activity 200 $\mathrm{Ci} /$ mmol (New England Wuclear)

- diethylstilbestrol ; (DEs) (Sigme)

- protamine sulphate (art.nr. 10123, Merck/Darastadt)

- all other chemicals used were analytical grade quality.

\section{REAGENTS}

- buffers are composed as indícated in table 4-1

- protamine sulphate solutions:

1) $2 \mathrm{mg} / \mathrm{ml}$ in buffer $\mathrm{nr} .1$ to be used in the centrifugation method

2) $1.2 \mathrm{mg} / \mathrm{ml}$ in buffer $n \mathrm{r} .2$ to be used in the filtration method

- tracer solutions:

${ }^{3} \mathrm{H}-\mathrm{E}_{2}$ and ${ }^{125} \mathrm{I}-\mathrm{E}_{2}$ in buffer $\mathrm{nr} .1$ to be used in the centratugation ane thod:

${ }^{3} \mathrm{H}_{-\mathbb{E}_{2}}$ in buffer nr.2 to be used in the filtration method 
table $4-1$

Concentrations (mold 2 ) of constituents of buffers used in protomine auphate precipitation asaze of aetrogen receptom

\begin{tabular}{|c|c|c|c|c|c|c|c|}
\hline buffer nr. & tris & $\operatorname{EDTAN}_{2}$ & $\mathrm{NalN}_{3}$ & DTT & $\begin{array}{r}\text { triton } \\
x-100\end{array}$ & ethanol & $\mathrm{pH}$ at $0^{\circ}$ \\
\hline 1 & 10 & 1 & 3 & 0.5 & - & - & 7.9 \\
\hline 2 & 20 & 3 & 1.5 & 1 & - & - & 7.9 \\
\hline 3 & 20 & 3 & 1.5 & 1 & $1 \%$ & $7 \%$ & 7.9 \\
\hline
\end{tabular}

- al1 concentrations in mol/1 except otherwise indicated

\section{CYTOSOLS}

The cytosols were prepared as follows:

$500-600 \mathrm{mg}$ of frozen human breast cancer tissue or calf uterus tisste were pulverised in a stainless steel mortar imersed in liquid nitrogen. The obtained frazen rough powder was then vibrated during 45 seconds three times, at 50 cycles/second in a tefion vial with a micro dismembrator (Braun, Melsumgen/Cermany). The resulting frozen fine powder was transferred to a $5 \mathrm{ml}$ polypropylene ultracentrifugation tube whereupon $3 \mathrm{ml}$ buffer (buffer $\mathrm{nr} .11$; table $4-1$ ) at $0^{\circ}$ were added. The tube was stoppered and vibrated for another two mimutes with the microdismembrator. The volume was then adjusted to 5 an with the buffer and the contents of the tube thoroughly miked. After 30 minutes ultracentrifugation ( $100,000 \mathrm{~g} ; 1^{0}$ ) the tube was laterally punctured and the supernatant collected avoiding contamination with lipids from the surface of the liquid.

When this procedure was followed cytosols were obtained containing protein between $2-4 \mathrm{mg} / \mathrm{ml}$. Protein concentration was determined by a biuret method with centrifugah analysis (this thesia; chater s) with correction for contaninating serum proteins. 


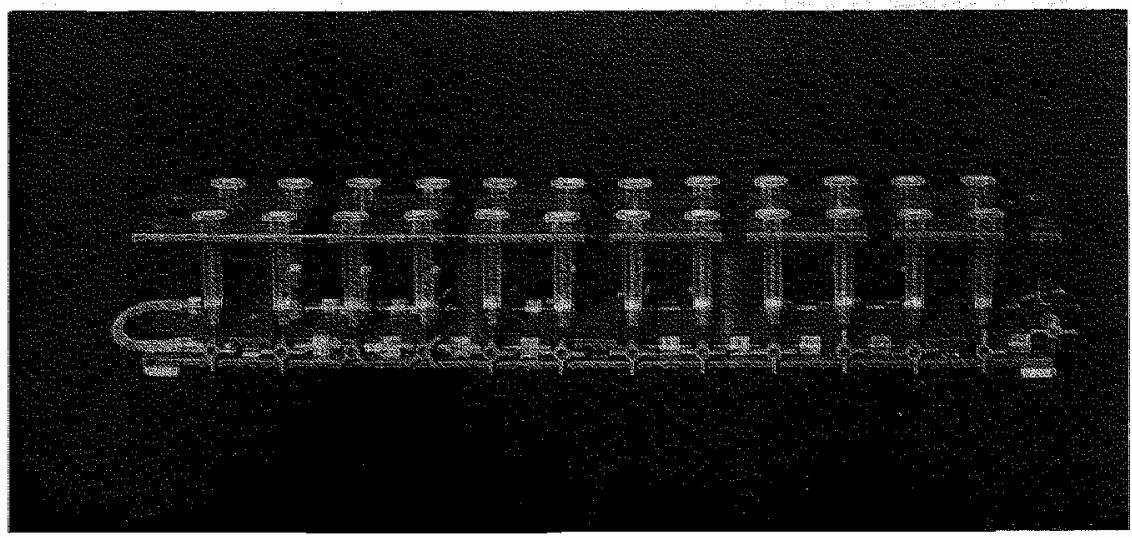

figutio $1-1$

Spectat equipment for semal incubations and putration toe tow

\section{SPECIAL EQUIPMENT}

A Filtration device was constructed using plastic syringes (inner diameter $9 \mathrm{~mm}$, height $55 \mathrm{~mm}$, cotall wolume $3 \mathrm{ml}$ ). At the botcon of the syringes stainlless steel grid discs were placed as siuports for Whatman GN/C glass fiber filcers $(10$ m diamecer, rougly side unwardsh. Hach syringe was connected to a threw way stopeack. A series of 24 w these so constructed filtration devices were cuupled and the cunison outlet connected to the vacutim pump ( gham $9-1)$. 


\section{CENTRLEUGATIOH METHOD}

It wust be marked that the whole procedure was perfarmed at $1^{\circ}$.

The protamine sulphate precipitation proedure was performed in acid washed glas tubes ( $11.5 \times 75$ wa ) by adding $250 \mu 1$ of protamine gutphate solution ni.l to a sample of 250 wl of cytosol. The mixture was vortexed, left for 5 mutes and next centrifuged ( $1000 \mathrm{~g}$ ) for 5 minutes the formed precipitate thus "coated" the battoms of the tubes and the supernatant could easily be removed by suction. Tracer was then added to the precipitates in the tubes and the total incubation mixcure volume made up to 250 will buffer ( buffer nx. I; table 4-1.); final concentrations of tracer were viz. $0,5,10,15,20$ and $25.1010 \mathrm{M}$. After incubation overnight ( 18 hours) the supernatant was removed by wction and the remaining precipitate washed three times with $2 \mathrm{mi}$ portions each of buffer nr.1. Similar series of experiments were performed with both tracers, $\mathbb{i} . e .3^{3} \mathrm{H}-\mathrm{E}_{2}$ and $125_{\mathrm{I}-\mathrm{E}_{2}}$. In the lodime tracer experiments the radioactivity of the cubes was measured ditrectly after the washing procedures. In the tritiun tracer experiments the precipdtates in the tubes were extracted twice with $1 \mathrm{mi}$ porcions of tetrahydrofuran each at room temperacure. The extracts from each tube were collected and combined in scintillation vials and after addition of sintillation 1 iquid the radioactivity was measured.

\section{FILTRATION METHOD}

As with the centrifugation method the filtration procedure was allso performed in a cold raon at $1^{\circ}$.

Af ter molatening the filters with 200 wl portions each of buffer (buffer nr. 2; table 4-1) and removal of the buffer by suction througth the filters the stopcocks were closed. Consecutively $90 \mu \mathrm{\mu}$ of protamine sulphate solution nr.2, $90 \mu 1$ of cytosol and another $90 \mu 1$ of the same protamine sulphate solution were pipetted into the syringes. After wigorous shaking of the filtration device in order to mix the contents 
of the syringes the precipitate was allowed to form for 15 minutes. The stopcocks were then opened and the solution removed by gentle suction. After closing the stopcocks tracer $\left({ }^{3} \mathbb{H}-\mathbb{E}_{2}\right)$ was added to a series of six syringes with equal contents to obtain final tracer concentrations of $20,5,10,15,20$ and $25.1010 \mathrm{M}$, with or without sinultameous addition of DES ( 200 -fold concentration) to control non-specific protein binding. The total volume in the incubation mixture vas made up to $200 \mu \mathrm{l}$ by addition of appropriate amounts of buffer (buffer nr. 2 ; table $4-1$ ). The contents of the syringes were mixed by shaking and incubation was petformed overnight ( 18 hours ). Afterwards, the liquid was removed by suction and $3 \mathrm{ml}$ af wash-buffer (buffer m. 3 ; table $4-1$ ) was put in the syringes, left in place for 5 minutes and removed by suction. The precipitate was then rinsed four times with light suction by application of 2 ml portions each of buffer on each filter. These washings were done directly whthout incubation. Finally suction was applied for some minutes untill filters were dry. The filters were then removed from the syringes and put in vials containing $10 \mathrm{ml}$ of scintillation liquid, and the radioactivity was measured,

\section{RESULTS AND DISCUSSION}

The basic principle of the protamine sulphate precipitation methods for the determination of oestrogen receptors is the binding and the quantitative measurement of specifically protein bound tracer ( $i$.e. labelled oestradiol $\mathrm{\gamma}$. Correction for non-specific binding is made by addition of an excess of a competitive "cold" ligand (DES). The specific receptor proteins are then saturated with cold 1 igand and the formation of these receptors with radioactive tracer provented. Residual radioactivity must be contributed to the ongoing binding of tracer to non-specific proteins.

Reliable results in the receptor assay can only be expected the 


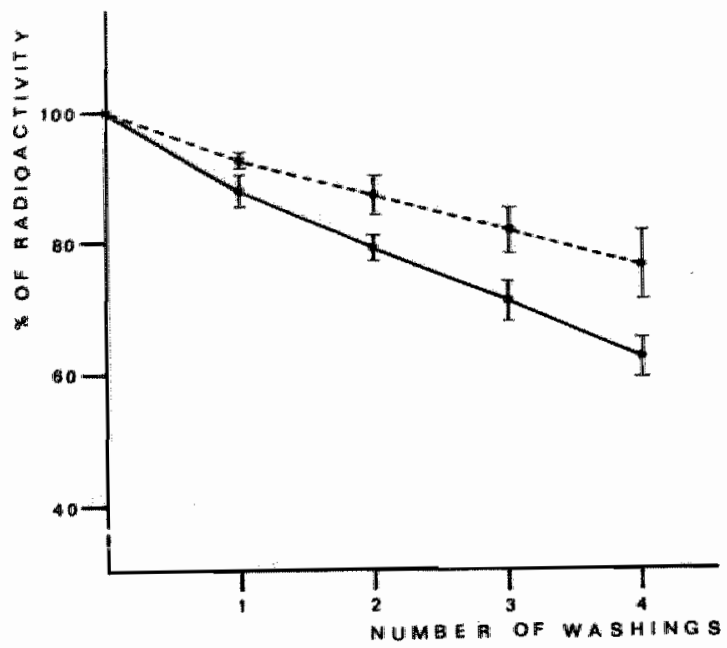

fingure 4-2

Las of radioactivity from protamine ulphathe / raceptor precipitate (see text), inubation withow (broken line) and with oEs (solid itine)

removal of free tracer from the precipitate can quantitatively be performed. Loss of protein bound tracer inevitably results in unduly decreased values for oestrogen receptor. It has been reported that in a comparative study of procedures the lowest values for oestrogen receptors were found with a protamine sulphate precipitation technique (12). This might be expliatned either by loss of tracer-receptor complex as such in the washing procedure of the precipitace or by lass of tee tracer due ta disociation of the complex during this washing procedure. Hashing the precipitate can nat be totally omitted on account of the presence of adhering free tracer on the precipitate after the tracer excluange incubation procedure. Other authors, however, published satisfactory results ( 13 ) especially in the determination of nuclear oestrogen receptor in adult rat uterus tisue ( 14$)$. Elsewhere, oestrogen receptor values determined in 
rabbit uterus cytosols were found higher with the protamine sulphate technique than with the dextran coated charcoal method, whilst the opposite was true for cytosols from human breast cancer in the same investigation $(15)$.

These considerations suggested close investigation of possible loss of radioactivity during the washing procedures. In the centrifugation method the removal of tracer was measured. Continuous loss of radioactivity with every wash cycle was observed ( figure $4-2$ ). As repeated washings of the precipitate resulted in increasing loss of radioactivity, the oestrogen receptor values estimated in this procedure were apparently dependent on the number of wash cycles. It could not be established whether only free tracer was gradually washed out or that tracer-receptor complexes were dissolved in the washing buffer and eliminated in this way, and this perhaps together with unspecific tracer-protein complexes. A third possibility to be considered was that the tracer-receptor complex dissociated during repeated washings and the 1 iberated tracer was then remowed. Anylhow, the values of the receptor concentrations as found by this method could not be considered to be reliable which is in agreement with earlier cited literature ( 12 ). It had been suggested there that possibly considerable amounts of non-specific tracer protein complexes were washed away or that tracer dissociated easily from these complexes. This quite well is in accordance with our observations that after suppression of specific tracer binding with DES, the decrease in radioactivity with wash cycles was larger than when specific tracerreceptor complexes were formed in the absence of DES (figure $4-2)$. It must be concluded that although the dextran coated charcoal method for the determination of oestrogen receptor is not without problems ( this thestig, chapter 2 ), no improvement could be achiced by adopting the protamine sulphate precipitation procedure with the centrifugation technique.

The introduction of the filltration method was based on the intention to prevent or reduce loss of radioactivity from the tracer-receptor 
tabte

Comparitson of oestrogen receptor vatues in hwan breast cancer cytoatdi detemination by protomine auphate precipitation techiques and by the dextran coated charooal assay.

\begin{tabular}{|c|c|c|c|}
\hline \multirow{2}{*}{$\begin{array}{c}\text { cytosal } \\
\text { n. }\end{array}$} & $\begin{array}{r}\text { protamine sulph. } \\
\text { techniques }\end{array}$ & $\begin{array}{c}\text { diextr.c.charcalal } \\
\text { assay }\end{array}$ \\
\cline { 2 - 4 } & $125 \mathrm{I}_{2}-\mathrm{E}_{2}$ & ${ }^{3} \mathrm{H}^{-\mathrm{E}_{2}}$ & ${ }^{3} \mathrm{H}-\mathrm{E}_{2}$ \\
\hline 1 & 84 & 62 & 129 \\
\hline 2 & 199 & 170 & 274 \\
\hline 3 & 401 & 433 & 525 \\
\hline 4 & - & 22 & 31 \\
\hline 5 & - & 15 & 11 \\
\hline 6 & - & 132 & 180 \\
\hline 7 & - & 24 & 83 \\
\hline
\end{tabular}

- cytosol nrs 1 - 3: protamine sulphate (centrifugation) technique

- cytosol nrs $4-7$ : protanine sulphate (filtration) technique

complex in the washing procedures. It was supposed that the absence of centrifugation after incubation and exchange of tracer peraits a rapid wahing out of free tracer without loss of specific material (1I). Unfortunately we could not confirm this. The loss of radioactivity was less than with the centrifugation method but still with act wash cycle tracer was removed. With the first wasting the disappearance of tracer from the filter was about $8 \%$ equal to the 108 in the centrifugation procedure. This was regarded to concern 
the washing out of free tracer. The radionctivity decrease on the filter with following rinse cycles wa less, wia. totalling $\| 1 \%, 15 \%$ and 18\% for the second, third and fourth cycle. Here too the loss of activicy was larger in the presence of DES suggesting that unspecific activity was removed with each rinse cycle or that fxee tracer after dissociation of the tracier receptor complex, or the latter as such, was washed away. Loss of radioactivity in the presence of DES was after first and following washings viz. $11 \%, 16 \%, 22 \%$ and $29 \%$

Finally some cytosols were analysed both with protanine sulphate precipitation procedures and withe the dextran coated charconl method ( table $4-2$ ). No agreement between the procedures was found. It must be concluded that with our cytosols the applied protanine precipitation techniques offered no real advantage over the dextran coated charcoal technique as recommended by the European Organisation for Research and Treatment of cancer $(1)$.

\section{REFERENCES}

1. E.O.R.T.C. Breast Cancer Coperative Group (1973) Standards for the assessment of estrogen receptors in human breast cancer. Eur. J. Cancer 9, 379-381

2. Ralet, Ph.G.F.A.H. and Brombactuer, P.J. (1981) the use of coated charcoal in the determination of oestrogen receptor activity. Eur. J. Nucl. Med. (in press)

3. Clark, J.H. and Gorski, J. (1969) Estrogen receptors: an evaluation of cytoplasmic-muclear interactions in a cell-firee systems and method for assay. Bioch. Boph. Acta 192, 508-515

4. Ralet Ph.G.F.A.H. (1981) This thesis, chapter 8

5. Tobin, E.H., Bloom, N.D., Pertschuk, L.P., Berman, P.J. and Degenshein, G.A. (1977) Estrogen and progesterone receptor proteins in human mamary carcimoma. Pag. 18\|-197 in: Agarwal, M.K. (Ed.) MuItiple wolecullar forms of steroid hormone receptore 


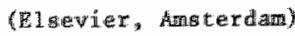

B. Jensen, E. V. (1975) Estrogen receptors in hormone-dependant breast cancer. Cancet Research $35,3362-3364$

7. Ginsburg, M., Greenistein, B.D., Mc Luski, N.J., Morris, I.D. and Thomis, P.j. (1974) An improved method for the study of high affinity ateroud binding. Steroids 23,773-792

B. Wagner, R. (1978) Extracellular and intracellular steroid buting proceins. Acta Endocrinol. (Khi) suppl. 218, 20-22

9. Steggles, A.W. and King, R.J.B. (1970) The use of protamine to study $\left(6,7-{ }^{3} \mathrm{~h}\right)$ oestradioll $-17 \mathrm{~B}$ binding in rat uterus. Biochem. J. $118,695-701$

10. Chamess, G. C." Huff K. and Mc Guire, H.L. (1975) Protamineprecipitated estrogen receptor: a solid-phase ligand exchange \#ssay, Steroids: 25, 627-635

11. Levy, C., Eychenne, B. and Robel, P. (1980) Assay of nuclear eatradiol receptors by exchange on glas fiber filters. Bioch. Biopti. Acta $630,301-305$

1.2. Jungbitut, W. W. "Hughes, S., Hughes, A. and Wagner, R.K. (1972) Evaluation of various methods for the assay of cytoplastic oestrogen receptors in extracts of calf uteri and human breast cancers. Acta Endocrinol, 70, 185 - 195

13. Lippman, $M$. and Huff, $K$ (1976) A demonstration of androgen and estrogen receptors in a human breast cancer using a new protamine suphate assay. Cancer $38,868-874$

14. Zava, D.T., Harrington, N.Y. and Mc Guire, H.L. (1976) Nuclear estradiol receptor in the adult rat uterus: a new exchange assay. Biochemistry 15, 4292-4297

15. Brownlee, N.R., Alonso, K.B., Crawforf, R.G. and Kohl, H. (1978) Comparigon of protamine suphate and dextran coated charcoal assays for estrogen receptor. Clinical Chemistry 24,1004 
chopter. 5

PROTEIN DETERMINATION

IN MAMMARY TUMOUR CYTOSOLS

SUMMARY

The various methods for the determination of the concentration of total proteins in mammary tumour cytasols were investigated. The different procedures for this determination of the usually low levels of protein produce different values. This is explained by differences in the underlying reaction mechanisms and by the use of various protein standards in the methods described. A proposal is made for the standardisation of both the analytical procedure and the reference protein mixture (horse serum) to be used as a standard. It appears that the biuret reaction serves best in the standardisation of protein determination. An analytical procedure has been developed in which centrifugal analysis is performed and whereby the sensitivity and precision of the biuret reaction are improved. The importance of an wnamiguous analysis of total protein is stressed, as this is the basis for the estimation of the oestrogen receptor concentration in the cytosol.

\section{INTRODUCTION}

The expression of oestrogen receptor activity in tissues meets a nuniber of problems where the concentration af recuptor protein is concerned. The ideal situation would exist if the concentration of receptor protein in terms of specific receptor binding capacity per cell (together with the number of cells per quantity of tisgue) could 


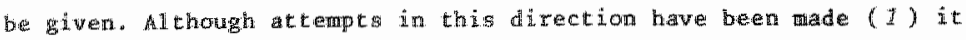
i.s wery difficult to produce accurate data in this way. Another approach is to refer to the receptor protein in terns of concentration wa. total protein either in the tissue itself or in a cytosol prepared frow the timsue (2). Expression of the receptor protein concentration with reference to nucleic acid concentration was reported in nuclear fractions of tifsue homogenates $(3)$. The destrogen receptor concentration is now generally expressed in terms of aestragen binding capacity in femtomoles per mg total protein in the cytosol prepared From the tisgue under investigation (a). It wast be kept in mind, however, that not only the receptor concentration but also the affitity of the receptor protein towds destrogens are important characteritefics. A correction for so-called mon-specific binding is made.

In the Netherlands, 17 laboratories are participating in a guality control programme on the measurement of oestradiol receptor. concentration in tissue from mamary gland tumours. Initially, the results produced by different laboratories could hardly be compared, which was to some extent due to the divergent data given for protein concentrations in the cytosol preparations distributed ( 5$)$. It is obviously quite difficult to obtain "true" values for very low concentrations of proteins as fiound in these cytosols. The problet is complicated by the fact that several procedures for the protein determination unfortunately lead to different results. Although much work has been done on the comparison of methods, no general agreement has been reached $(6,7,8,9)$. For this reason some of the protein determination procedures used in the earlier mentioned quality comtrol scheme were compared by us in order to determine which method could best be recomunended.

te should be noted that the E.O.R.T.C. (European Organisation for Research and Treatment of Cancer) advisie a protein determintion method based on the affinity of the dye Coonassio Brilliant Blue for protein, using a commercial human serum albumin preparation as a standard (Kabi ${ }^{\text {F }}$ standard, cen fold diluted) (10). Although the 
chotce of this dye-binding procedure is understandable in view of its reported sensitivity, a simple biuret reaction was thought to be preferable on account of its general applicability to any protein. In this reaction all peptide bonds are measured almost independant of the protein conposing amino acids. The sensitivity of the biurec reaction is reported to be further entanced by the introduction by Lowry of the Folin phenol reagent.

Thus, three procedures were considered, the wellknown biuret reaction which is still widely used (11), the Lowry method using the Folin phenol reagent especially developed for low protein concentrations ( 12 ), and the determination of protein concentration by measuring the binding of the dye Coomassie Brilliant Blue (13).

Buret method: The well-known biuret reaction is perhaps next to the Kjehldahl analysis the most widely used procedure for determination of proteins in solution. Tts non-selective character is generally an advantage because the method can be used for every protein solution. Important advantages are found in the determination of low protein concentrations in small sample volumes when a centrifugal analyser is used. The introduction of this technique enables analyses to be performed on scale which hitherto has not been possible. "This technical improvement can be applied to the cllassical biuret reaction. The specific problem was the quantification of total protein present in cycosols in the range of 0.5 to $6.0 \mathrm{mg} / \mathrm{ml}$.

Lowry method: The Lowry method for protein determination combines the biuret reaction for the detection of peptide bonds with the Folin Ciocalteu reaction for the detection of phenolic oh-groups (12). In this way the residues from phenolic anino acids in the protein solution provide an extra contribution to the final colour of the reaction mixture.

Comassie Brilliant Blue thethod: The use of the so-called protein dye Comassie Brilliant Blue in the quatification of proteins bas boen suggested by Bradford (13). Although the procedure described appears to be rapid and reproducible, it is only af limited analytical value because it shows a wide variability in its sensitivity co various 
protejns (14). Incortect vallues have been reported when human serum albumin or bowne globulin were used as the standard (15). This is al together not too surpriting because in dye-binding methods only polypeptide woteties of proteins are evaluated, so that lipo- and 1yco-proteing are relatively anderestimated. Moreover, various proteins are not equally rich in dye-fixing basic groups wich explatis different sensitivity for different proteins. Human serum albumin is perthaps the most sensitive for dye fixation. Nothling can be predicted about the affinity of the dye for specific aestrogen receptor proteins.

The determination of tumour protein is further complicated by the fact that in cytosols prepared from tumour tissue a certain amount of verum protein is always found. In extreme cases up to $50 \%$ of the total protein content is found to consigt of human serum alburin. It goes without saying that correction for this non-tumour protein must be made in order to make a correct estimate of the receptor protein, expressed in terms of oestrogen binding capacity vo, total proteitn.

\section{MATERIALS}

A11 chemicals used were comercial products of analytical grade.

1. TED-buffer.

Tris-HCl buffer $10 \mathrm{mM}$, pH 7.5 at $23^{\circ} \mathrm{C}$ containing $1 \mathrm{mM}$ EDTA, $3 \mathrm{mM}$ $\mathrm{NaN}_{3}$ and $0.5 \mathrm{~m}$ dithiochreitol.

2. Biuret reagent.

The concentrated biuret reagent (Roche Diagnostica) consisted of an aqueout solution containing potassüum sodium tartrate 200 mmol/1, copper sulphat 120 mol/1, potasium iodide 100 monol/1, and sodium hydroxide 2 mo $1 / 1$.

3. Lowry reagentis.

a. Sodium carbonate $180 \mathrm{mmol} / 1$ in sodium hydroxide $100 \mathrm{mmo1/1}$.

b. Copper sulphate 20 mol/1 in potassium sodium tartrate 35 mol/1. 
c. Carbonate copper solution: $50 \mathrm{ml}$ of reagent a and $1 \mathrm{ml}$ of reagent b were mixed before use.

d. Phenol reagent of Folin ciocalteu. A mixture consisting of 100 of soding tungstate ( $\mathrm{Na}_{2} \mathrm{WOO}_{4}, 2 \mathrm{H}_{2} \mathrm{O}$ ) " $25 \mathrm{~g}$ of sodium molybdate $\left(\mathrm{Na}_{2} \mathrm{NoO}_{4}, 2 \mathrm{H}_{2} \mathrm{O}\right), 700 \mathrm{ml}$ of water, $50 \mathrm{ml}$ of $85 \%$ phosphoric acid, and $100 \mathrm{ml}$ of concentrated hydrochloric acid in a 1.5-1 flask was refluxed gently for 10 hours. Thereafter $150 \mathrm{~g}$ of lithium sulphate, $50 \mathrm{ml}$ of water, and a few drops of bromine water were added and the mixure was boiled for 15 minutes without condenser to remowe excess bromine. After cooling, the solution was diluted to $1 \mathfrak{l}$, and filtered. The reagent had no greenish tint. (The acid concentration of the reagent was determined by titration with 1 N NaoH to a final $\mathrm{pH}=9.0$.) The acidity of the reagent had to be about $1 \mathrm{~N}$. (The reagent is also commercially available in a concentrated solution, Merck 9001, which after dilution with an aqual volume of water is ready for use.)

4. Coomassie Brilliant Blue reagent.

$100 \mathrm{mg}$ of Coomassie Brilliant Blue G-250 (C.I. 42655, Sigma B 5133) was dissolved in $50 \mathrm{ml} 95 \%$ ethanol. To this solution $100 \mathrm{ml}$ phosphoric acid 85\% (w/v) were added. The resulting solution was diluted co a final volume of 1 liter. Final concentrations in the reagent: Coomassie Brilliant Blue G-250: $0.01 \%(w / v)$, ethanol $1 M$, and phosphoric acid $1.48 \mathrm{M}$. The dye reagent had always to be filtered (ower whatman no. I filter paper) just before use." (The reagent is also commercially available as a dye reagent concentrate, Bio Rad, which can be used after dilution with four volumes of water.)

5. Proteim standards.

a. Seronorm (lyophilised horse serum, Nyegaard \& Co, Oslo, Norway), lot no. 138 ; containing $67.0 \mathrm{mg}$ total protein/ml (biuret mettod), $26.0 \mathrm{mg}$ albumin $/ \mathrm{ml} ; 10.77$ mg protein mitrogen $/ \mathrm{mll}$ by kjeldahl analysis after dissolving in $10.0 \mathrm{ml}$ of $\mathrm{H}_{2} \mathrm{O}$ (apparently protein factor of 6.22 is used). 
b. Kabi Diagnostica Protein standard (hum serum albumin dissolved in physiological saline, Kabi Stockholn, Sweden), lot no. 57739 ; containing $103.8 \mathrm{mg}$ humata albumin/mi (Rjeldahi-analysis, protein factor 6.4.4; 16.22 mg protein nitrogen/m1.

c. Bio-Rad Protein Assay standard I (bovime plasma globulin Iyophilised, Bio Rad Lab., Kichnond, California, V.S.A.), lot no. 17893; contalning 1.39 movine globulin/ mi after addition of 20.0 前 $\mathrm{H}_{2} \mathrm{O}$.

6. Working standards.

a. For the biuret method the following protein working standards were prepared by dilution with $\mathrm{H}_{2} \mathrm{O}$ and TED-buffer: reconstituted horse serum (Seronom) $0.94,1.86,3.79,6.09$, $8.38,9.57$ mig protein / thl ; reconstituted hutan serum albumin solution (Rabi standaxd) $1.30,2.60,3.89,5.19,6.23,7.74,10.38 \mathrm{mg}$ protein $/ \mathrm{mi}$; reconstituted bovine globulin solution (Bio-Rad standard) $1.39,2.78,5.56,8.34,11.12,13.9 \mathrm{mg}$ protein / ml.

b. For the more sensitive Lowry method, the first two standards were diluted ten fold, respectiwely in $H_{2} O$ and TED-buffer, in order to obtain afficiently low concentrations.

c. For the Coomasie Brilliant Blue arethod five fold dilutions of the working standards sub a, re made.

\section{METHODS}

Biuret method. Procedure: In ordex to enhance the sensitivity of the method and to reduce the amount of sample needed a procedire for centrifugal andysi was deweloped, in which concentrated reagent could be used. This procedure is specified in table $s-1$.

Lowry method. Procedure: Samples and standards were diluted ten fold before use. To $0.40 \mathrm{ml}$ of diluted sample, alluted standard, water or TED-buffer (blankis), 2,0 mll of reagent 3 .c mere added, miked and 11 lowed to stand for 10 minutes at room temperature; then 
tabte $5-1$

Scheme for the detemititation of proteins in solution by the buret meaction (centrifugat analysis procedure). Somples ard strandards ane uate andiluted. Horse semon protain standards are dssolved in TEDbuffer.

\begin{tabular}{|l|rl|}
\hline temperature & 30 & ${ }^{\circ} \mathrm{C}$ \\
type of analysis & 7 & \\
wave length & 546 & $\mathrm{~nm}$ \\
sample volume & 40 & $\mathrm{\mu l}$ \\
diluent volume $\left(\mathrm{H}_{2} \mathrm{O}\right)$ & 40 & $\mathrm{\mu l}$ \\
reagent valume $\left(\mathrm{H}_{2} \mathrm{O}\right)$ & 200 & $\mathrm{\mu l}$ \\
incubation time & 30 & $\mathrm{sec}$ \\
starting reagent volume (biuret) & 40 & $\mathrm{HL}$ \\
time interval (reaction time) & 300 & $\mathrm{sec}$ \\
standard I concentration & $1.86 \mathrm{mg} / \mathrm{ml}$ \\
standard 2 concentration & $6.09 \mathrm{mg} / \mathrm{mL}$ \\
standard 3 concentration & $9.57 \mathrm{mg} / \mathrm{mL}$ \\
\hline
\end{tabular}

* machine code indicating a method with blank subtraction

$0.2 \mathrm{mi}$ of reagent $3 . \mathrm{d}$ was quickly added and the contents of the tube were irmediately mixed. After 30 minutes the absorbance of the samples, standards and blanks was read against water at 520 nan in a spectrophotometer using a $1 \mathrm{~cm}$ cuvette.

Coomasie Brilliant Blue method. Procedure: Samples and standards were diluted five fold with either water or TED-buffer before usie. To 0.1 mo 1 of samples (diluted), standards (düluted), water or TEDbuffer 5.0 m1 of Coomasie Brilliant Blue $G=250$ reagent were added and mixed. After 10 minutes, optical densities were read at $595 \mathrm{~nm}$ in a spectrophotometer using 1 cm cuvettes against reagent blam, water blank or TED-buffer blank. After each reading " the cuvettes were rinsed with methanol and water to elfminate any trace of dye. 
CHOICE OF A PROTEIN STAHDAQD

The determination of total protein in cytosols prepared from human breast thmours is of fundamental importance as long as oestrogen receptor activity is expressed per wig protein. The tocal protein cantent serves as a parameter for the amount of tumour tissue represented by the prepared cytosol. One of the problems is that most determination procedures are based on the use of so-called standard solutions containing a known amounc of proteln $(8,9,10)$. The latter preferably has to be of the very same nature as the proteins in the sample to be analysed. This, luowever, is wirtually impossible in the estimation of oestrogen receptor protein or total proteins in the cytosol. Receptar proteins are not awailable in a highly purified state and the protein pool in cytosols is composed of dhferent tissue proteins and a variable amount of plasma proteuns. It is, therefore, not surprising that the composition and nature of the protein standards used have a marked influence on the results of the deterraination of oestrogen receptor concentrations. These effects are, of course, stronger when the reaction by which the protein is determined is more specific for special proteins. It can easily be understood that a "generall" reaction (i.e. one without preference for specific characteristics of certain protein mollecules) is more suitable when a mixture of different species of protein is to be investigated. The biuret reaction serves this purpose quite well, while a more sensitive reaction such as the one described by Lowry is more dependent on the amoum of phenolic amino acid residues in the proteins. These phenolic groups are found to a different extent in various proteins. Finally dye fixation is also dependent on the nature and amino acid compostion of the proteins concerned (17). As was mentioned in the "introduction" geveral misleading results have been reported when this analytical procedure has been used. A standard composed of $70 \%$ human serum albumin and $30 \%$ human serum globulin was reconmended for use in Cof investigation (15). No special standard can be recomended for tumour proteins, although from an analytical point of view bovine globulin has been found to 


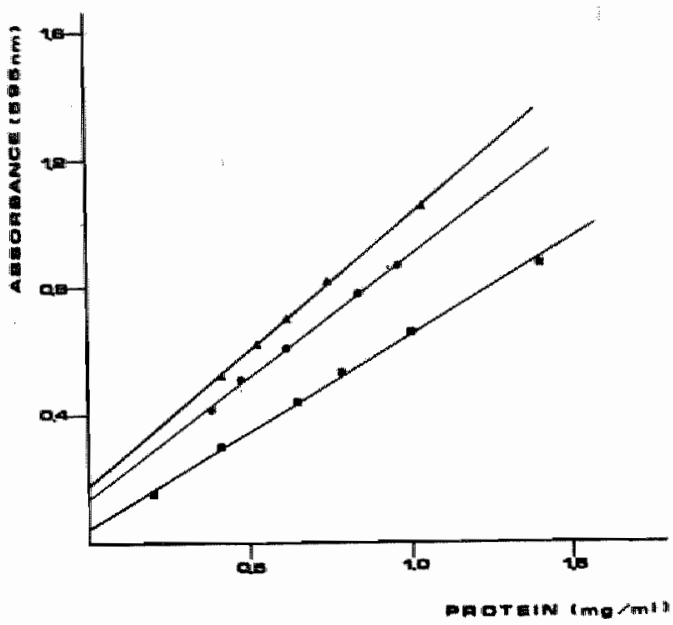

figure $5-1$

Protein altibration aurves by the Comassie Brilliam Blue method; the dye reagent was used as a blowk; m- human semalkumin; - - horse serum proteins; - - bovine serum globulin. Atl proteins were dissolved in water.

be preferable (figure 5-1) for use with Coonassie Brilliant Blue.

If a choice of standard has to be made from what has just been considered, a mixture of proteins seems to be the most suitable and there are no strong indications that any available specific protein is preferable. Therefore, whole serum preparation willich is easily obtaimed in such quantities that use of the same batch can be guaranteed for years is to be preferred. From the three standerds suggested the lyophlised equine full serum standard (Seronomit) has been chosen. The two other avalible standards are both incomplete preparations from blood, either human serum albumin or bovine plasma globulin. 


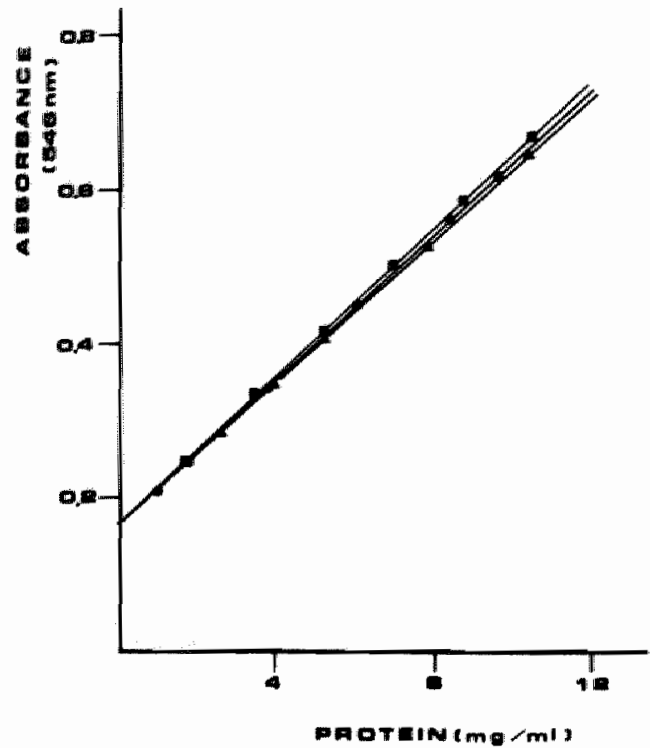

figure $5-2$

Protein alibration cumes by the biumet method (centmifugat anatysis'; absorbance read against water; - hanan gemom albumin; -- horse semum proteins; - - bovine semm globulin. All proteins were dissolved in water.

Sunmarising the reasons for preferring the complete horse serum (Seronorm ${ }^{R}$ ) preparation:

- It is a complete serum.

$=$ It is lyophilised and can easily be dissolved in water or in TEDbuter.

- Its composition is regularly checked by about 170 clinical chemistry laboratories in the Necherlands so that a good quantity of a standardised preparation is avallable. This is really an important reason to confirm the choice of this standard. 


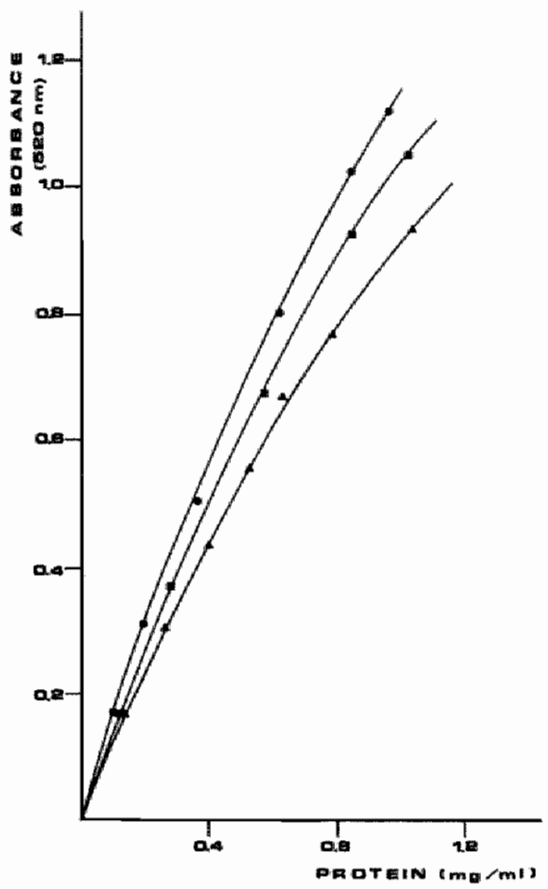

figure $5-3$

Protein calibration curves by the Lown method; TED-Buffer in reagent was used as a blank; - 4 human semum albumin; - - horge semam proterinc; $\rightarrow-$ bovine semun globulin.

Al2 proteting were dissolved in TED-buffer.

- In the biuret method the phatometric sensitivity for the three standards studied is only slightly different (figure $5-2)$ whilgt in the Lowry method the optical densicy obtained for a certain amount of protein is highest for complete horse sierum (fighere $5-3)$. 
IHTERFERELCES OF THE TED-BUFFEF CONSTITUENTS ON THE QUANTITATIVE DETERMINATION OF PROTEIMS

It is well known that many substances have an influence on the protein deterwination methods referred to in this investigation (18). Special attention was pald to the constituents of the buffer used, i.e. interfetence from $T$ Tris $(13,19,20,21,22)$ and (to a lesser extent) also from EDTA $(13,23)$. A number of procedural modifications were studied which were more or less succesful in eliminating this interference $(24,25)$.

Biuret method for protein determination in centrifugal analysis. It has been reported (20) that increasing the Tris concentration in

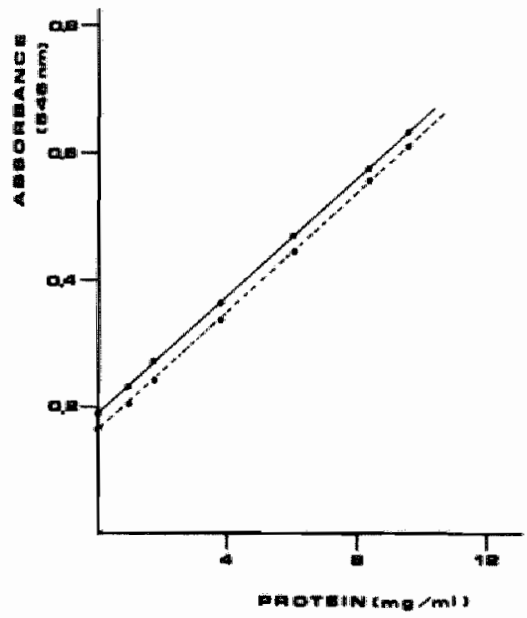

Ligure $5-4$

Calibration aurves by the biumet method (aentrifugat analysis) of horse serw protetns dissolved in TED-buffer (solid lime) or in water (brokan linel. Absorbance nead aganimst water. 
the buffer, both increased the optical density in the biurec reaction and decreased the slope of the protein calibration curve. Nevertheless, the absorbance in the presence of Tris was proportional to the protein concentration. In order to check this, calibration curves of horge serum (Sexonom ${ }^{R}$ ) were made in the range $0-10$ ag protein / mil when the contribution of the TED-buffer was found to equal approximately $0.5 \mathrm{mg}$ protein $/ \mathrm{m}$ (figure $5-4)$. The final molarity of "Tris in the

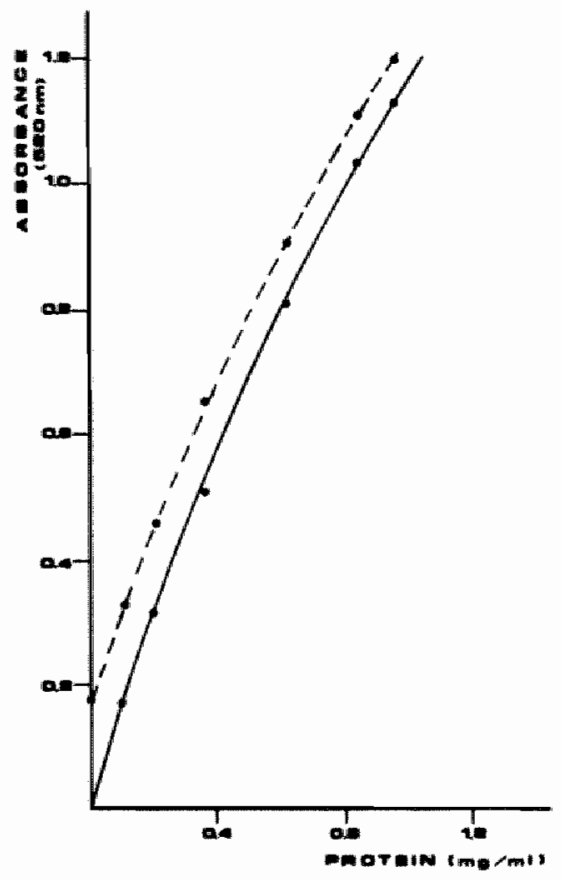

Ligure $5-5$

Caltbration curves of horse serm proteine dissolved in reD-buffer by the Lowry method. Absorbance read agatnet a blank containing either TED-buffer (solid line) or water (broken line) in reagent. 
in the biuret reaction was 1.25 . Similar results were obtained with other protein atadards, including humen serum albumin and bovine globulin. In the protein concentration range $0-10$ mo/ml there a distinct contribution from TED-buffer in biuret reagent to the optical density, but no decrease in the slope of the curve was found. Reading the samples against a blank containing biuret reagent and buffer resulted in a calibration curve through zero. The influence of the TED-buffer on the deternination of proteing in biuret reagent could not be denied, but interference could easily be compensated.

Lowry method. Using the Lowry method sitmilar interference phenomena were seen. This was no surprise because the contribution of Tris was due to complex formation with the copper in the reagent. In this

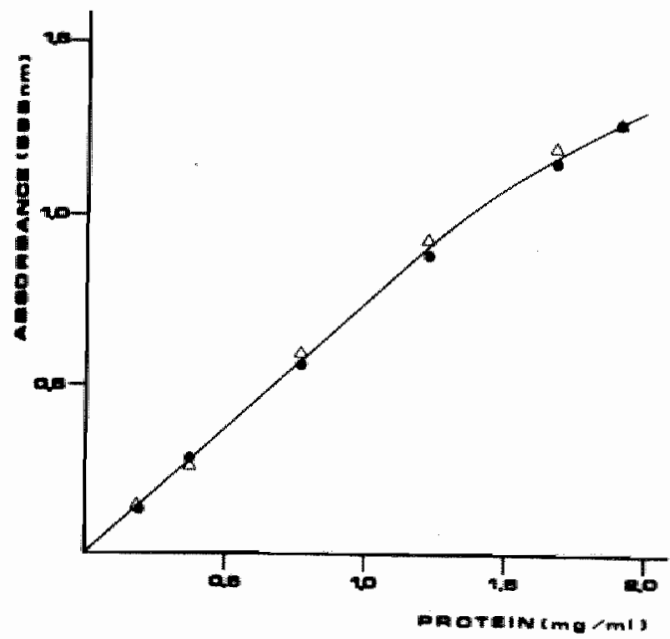

fituing $5-6$

Callbration oume of horse sem proteins dissolved in wED-buffer by

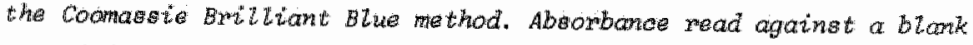

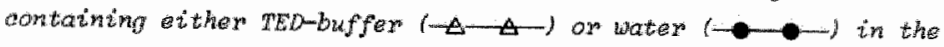
dye raggent. 
reaction the final molarity of Tris was 1.54. The calibration graph in the range up to $1.2 \mathrm{mg}$ protein / ml. was slightly curved. Anothex source of interference might have been reduction of the FolinCiocalteu reagent by EDTA (25). Again the use of TED-buffer as a blank fully eliminated the influence of the interference on the result of the analysis (figure $5-5$ ).

Coomassie Brilliant Blue method. In the comonly used binding method with Camassie Brilliant Blue, no interference thas been seen either Exom Tris or EDTA as used in the TED-butfer (figure $5-6)$.

Similar investigations as with Tris have bean performed with EDTA in the concentration ( $1 \mathrm{mM}$ ) as used in the buffer. It appeared that in this rather low concentration no influence whatsoever could be noted. These results were in agreement with those in the literature $(13,26)$. It must, therefore, be recowmended that the blank in the protein decermination consüst of the Full TED-buffer containing all constituents except protein.

\section{EVALUATION AND COAPARISON OF THE THREE CONSIDERED PROTEIN}

\section{DETERMINATION METHOOS}

In order to choose the best procedure for the determination of the protein concentration in cytasols to express aestrogen receptor concentration, the three methods described above were compared . As a standard 1yophilised horse serum. (Seronoms ${ }^{R}$ ) reconstituted in TEDbuffer was used.

The biuret reaction in centrifugal andysis was compared to the other procedures. Protein concentrations in the cytosols in the range $1.0 \mathrm{mg} / \mathrm{ml}$ to $4.5 \mathrm{mg} / \mathrm{ml}$ were determined. The protein calibration curve in the biuret reaction was perfectly linear.

The precision of the three methods was compared by deterninatian of standard deviations (from duplicate analysü) and coefticients of variation over the range studiad. It must be kept in mind that both for the Lowry procedure and the Comassia Brilliant Blue procedure 
table $:-2$

Comparison of three rathade for protein determination.

\begin{tabular}{|c|c|c|c|c|}
\hline \multicolumn{2}{|c|}{ method } & biuret & Lowry & Coomassie $\mathbb{B} . B$ \\
\hline \multicolumn{2}{|c|}{ range (mg/ml) } & $1.0-4.5$ & $0.10-0.45$ & $0.20-0.90$ \\
\hline \multirow{4}{*}{ 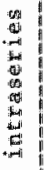 } & $n$ & 32 & 20 & 22 \\
\hline & $\overline{\mathrm{x}}$ & 3.11 & 0.394 & 0.7601 \\
\hline & $\Delta x d$ & 0.0334 & 0.010 & 0.011 \\
\hline & $\cos v$ & $0.95 \%$ & $2.7 \quad \%$ & $1.4 \%$ \\
\hline \multirow{4}{*}{ 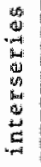 } & $\mathrm{n}$ & 42 & 28 & 32 \\
\hline & $\tilde{x}$ & 3.28 & $0.393 i$ & 0.555 \\
\hline & $\sin d$ & 0.056 & 0.017 & 0.038 \\
\hline & $\operatorname{arn}$. & $1.5 \%$ & $4.3 \%$ & $6.8 \%$ \\
\hline \multicolumn{2}{|c|}{ detection 1 imit } & 0.07 & 0.02 & 0.02 \\
\hline
\end{tabular}

- protein concentrations are given in mg/mil

- standard deviations were determined from duplicate analys is either intraseries or between series

- detection 1 imits were determined as twice the standard deviation of the blank

extra dulutions of samples and standards had to be made. Detection limits of the methods have been determined as twice the standard deviation for the blank. The results of this investigation are given in table $5-2$. From these figures it can be seen that the more sensitive Lowry procedure as campared with the biuret procedure had a lower degree of precision, which might perhaps be expected. The comparison between intra series coefficient of variation and inter series coefficient of variation in both methods was quite acceptable. This was not true for the Coomassie Brilliant Blue procedure. It appeared that the reproducibility (as expressed by coefficient of variation between series) of this procedure was less acceptable than 
for the others. It can readily be understood that wariation in dye fixation is more susceptible to changes on account of the complexity of dye binding and the possible variation of the reagents after filtration from day to day. For these reasons, the dye binding procedure was regarded by us as the least to be preferred.

A choice between the biuret reaction as such and the modification including a reaction on phenolic groups (Lowry procedure) was made on the basis of difference in precision and simplicity of performance. It should also be kept in mind that a greater influence of endogenous reducing substances can be expected in the Lowry procedure "The biuret method was easily performed because a procedure using a centrifugal analyser had been developed. The use of this type of analyser, although preferable on account of precision and the possibility of using small sample volumes, was not practicable for the Lowry method the reaction scheme for the latter method, requiring two incubations with an interval of about 15 minutes, took too much analyser time. Moreover, the second incubation itself required another 30 minutes and such a scheme was unacceptable in a busy laboratory. The necessity for predilution of samples and standards for the Lowry procedure was another disadvantage.

It can be concluded that the simple biuret method without predilution has the best precision and can be used satisfactorily in a centrifugal analyser. This method is, therefore, recomended.

\section{CORRELATION OF THE DIFFERENT METHODS}

The comarison of protein concentration measurements in 17 cytosols by the biuret method using a Cobs Bio centrifugal analyser and by the Coomassie Brilliant Blue procedure, was then gtudied. Lyophilised horse seram (Seronom ${ }^{k}$ ) reconstituted in TED-buffer was used as a standard. The result

Although the coefficient of correlation $(r=0.972)$ and the regression line $(y=1.1058 x+0.0374)$ were quite acceptable, it 


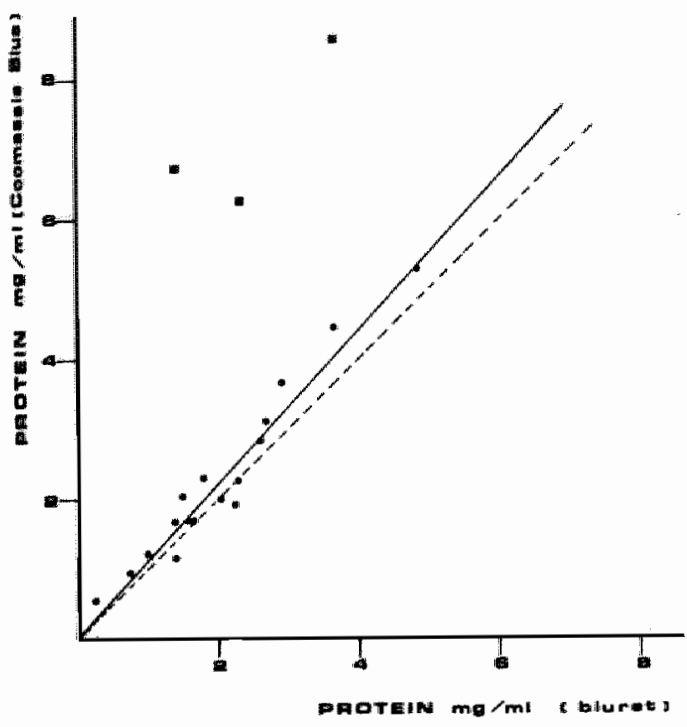

Migure $5-7$

Comparison of protein concentration measurements of 17 aytosols $(\bullet$ and 3 "haemolytic" aytosals (a) by the biunet me thod (Cobas bro centriflugal analyser and by the Coomaside Brilliant Blue pracedure; $y=1.1058 x+0.0374 ; \quad x=0.972 ;$ broken line $y=x$. As a stchaland $a$ solution of horse seman proteting in TED-buffer was used.

should be noted that no valid results could be expected with the Coomassic Brilliant Blue procedure if the cytosol contained traces of haemoglobin. In contrast to others $(16)$, we have found much gtronger haemoglobin incerference in this method than in the biuret method. In order to check this, a very dilute hemoglobin solution was added to some cytosols and grosily exaggerated values were then found in the Coomassie Brilliant Blue procedure (figure $5-7$ ). Most 


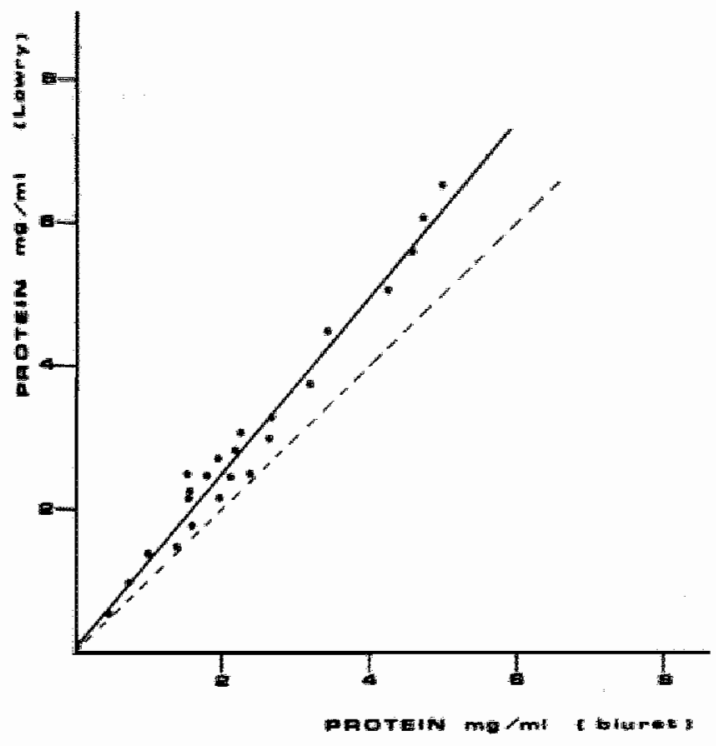

figure $5-8$

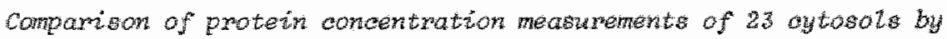

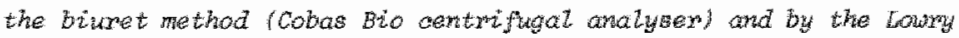
procedure; $y=1.2317 x+0.0341 ; y=0.987$; broken line $y=x$. As a

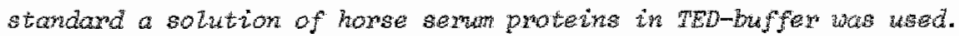

tumours cantain some blood which is almost impossible to wash fully out. This is another reason for preferring the biuret reaction to the Coomassie Brilliant Blue method.

A similar comparative study was made on 23 cytosolls where the protein content was determined both by the biuret method and the Lowry procedure (fügure $s-8$ ). Again, 1yophilised horse serum (Seronorm ${ }^{R}$ ) reconstituted in Ted-buffer was used as a standard. A satisfictory coefficient of correlation $(w=0.987)$ was found and the linear regression was $y=1.2317 x+0.0341$. The fact that the 
values found by the Lowry method were significantly higher than those found by the biuret method could be explained by apparently greater content of phenolic groups in the cytosol proteins than in the horse werum protein standard. Hother possibility was the interference of non-protein substances in the cytosols. It has been reported (22, 26) that this type of interference could be oxercome in the Lowry method by precipitating proteins prior to the determination. A certain risk, however, of losing protein, e.g. in a necessary washing procedure, is then introduced which is even more serious considering the low protein concentration in the cytasols. For this reason too, we prefex the simple biuret reaction for determimation of protein in cytosols from human mamary tumours.

\section{DISCUSSION}

From the investigation performed it can be concluded that no singlle method for the deterwination of total protein in cytosols from mammary tumours can be recomended as being superior. For reasions of rationalisation and in order to promote comparability of resultes from various laboratories, however, the simple biuret method which measures peptide bonds in all proteins is proposed. In our opinion this is an advantage so long as the structure and properties of purified receptor protein have not been elucidated.

of considerable importance also is the improved precision of the biuret method, which is reported to be $3 \%$ for the normal serum protein concentration of $60-80 \mathrm{mg} / \mathrm{ml}(11,17,27)$. In contrast, the method using centrifugal analysis yields a coefficient of variation of $1.48 \%$ even in the range of low protein concentrations in the cytosol $(1.0-4.5 \mathrm{mg} / \mathrm{ml})$ with a detection limit of $0.07 \mathrm{mg} / \mathrm{mil}$.

The biuret method is preferred to the Lowry method because the latter detect varying mounts of phenolic and sulfhydryl groups as well as peptide bonds in the various proteins. Because it is not 
certain that proteins in cytosols fron different tumours are always af the same amino acid composition and because of the different reactivity towards protein standards, the special feacures of the Lowry method will lead to less uniformity in this field of protein detemination $(9,12,17)$. That the influence of the amount of certain amino acids on the result of the protein determination is important is illustrated by the fact that the tyrosine content of different proteins in human serum may vary by a factor of five or nore (18, 29). Using the Lowry method, this can lead directly to considerable differences in the apparent protein concentration in serum. The same considerations concerning the standard proteins to be used also lead to a preference for the biuret method over the Lowry nodification.

From the correlation between the biuret reaction and the modified procedure as described by Lowry it can be seen that results obtained with the latter method were approxinately $23 \%$ higher than with the biuret reaction. On account of all these complications, preference is given to the simple biuret reaction.

Comparing these procedures with the Coomassie Brilliant Blue dye binding method for determination of protein concentration shows that the latter method has certain clear disadvantages despite its reported sensitivity (13). The qualitative composition of the dye is neither well defined nor guaranteed, and its binding properties are also dependent on many factors. The coefficient of variation between series is larger than for both biuret methods. Another great disadvantage, however, is the strong disturbing interference fron haemoglobin in the cytosol preparations which leads to exaggerated proteia values $(f i g u r e s-7)$.

From this study of oestrogen receptor concentrations it was concluded that the original biuret method performed in a centrifugall analysex was the method of choice for the determination of proteins in mamary cumour cytosols. It must be stressed once more that reliable protein determination is of the utmost importance. When the protein concentration is wrongly reported roo high this means that the ratio 
of spectif aestrogen binding capacity to total protein content is found to te too low. As a consequence, the decision might be taken that horenal treatment of the patient concerned should not be atarted. When, however, this deciston has been wrongly made, an important treatment for the patient is thus withheld.

\section{REFERENCES}

1. Martín, P.M. Rolland, P.H. Jacquemier, I., Rolland, A.M. and Toga, 1979 ) Maltiple steroid receptors in buman breast cancer. Cancer Chemother. Pharmacol. 2, 107-113

\%. Hälne1, R. and Twaddle, E. (1978) Estradiol binding by human breast carcinoma cytosols. Europ. J. Cancer 14, 125-131

3. Bayard, F., Danilano, 5., Robel, P. and Baulieu, E.E. (1978) Cytoplasmic and nuclear estradiol and progesterone receptors in human endometrium. J. of Clin. Endocrinology and setabolism 46, $635-648$

4. Sin Hane Lee, M. D. (1979) Cancer cell estrogen receptor of human manmary carcinoma. Cancer $44,1-12$

5. Koenders, A. and Benraad, Th.J. (1980) Kwaliteitscontrole vam steroidreceptor metingen. Tijdschr. Ned. Ver. Klin. Chemie 5 , $185-186$

6. Doumas, B.T. (1975) Standards for total serum protein assays. Clin. Chem. $21,1159-1166$

7. Cornall, A.G. and Manolis, A. (1977) Comments on a new biuret reagent, Clin. Chem. 23,1184-1185

a. Borij, $\pi$ (1972) Some divergent results of protein standardization. Clin. Chem. Acta 38,355-362

3. Peters, T., Jr. (1969) Propowals for standardization of total

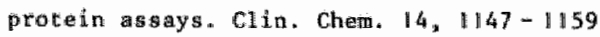

10. F.O.R.T.C. Breast Cancer Cooperative Group (1981) Standards for the assessmett of homone-sensitivity in humm breast cancer. Report of the second workshop on March 16/17, 1979, at the Antoni van Leeuwenhoek-Huis, Ansterdan (To be published) 
11. Cornal1, A.G., Bardawil1, C.I. and David, M.M. (1949) Detemination of serum proteins by means of the biuret reaction. J. of Biol. Chem. 177, 751-766

12. Lowry, 0.R., Rosebrough, N.I. Farr, A.L. and Randal1, R.I. (1951) Protein gaeasurement with the Folin phenol reagent. J. of Biol. Chem. 193,265-275

13. Bradford, M.M. (1976) A rapid and sensitive method for the quantitation of microgram quantities of protein utilizing the principle of protein dye-binding. Anal. Biochem. $72,248-254$

14. Pierce, J. and Suelter, $C$. H. (1977) An evaluation of the Coomassie Brilliant Blue G250 dye-binding wethod for quantitative protein determinatiom. Anal. Biochem. $81,478-480$

15. Johnson, J.A. and Lott, J.A. (1978) Standarditation of the Coomassie Blue Method for cerebrospinal fluid proteins. Clin. Chem. $24,1931-1933$

16. Bio-Rad laboratories (January 1979) Instruction manual for protein assay.

17. Schultze, H.E. and Heremans, I.F. (1966) "Mollecular Biology of human proteins", Vol. I, 83 (Elsevier Publishing Company, Ams terdam)

18. Layne, E. (1957) "Methods in Enzymology", Vol. III, 450-451 (Academic Press, New Yark)

19. Kuno, H. and Kihara, H.K. (1967) Simple microassay of protein with nembrane filter. Nature, $215,974-975$

20. Robson, R.M., Goll, D.E. and Temple, M.T. (1968) Determination of proteins in "Tris" buffer by the biuret reaction. Anal. Biochem. $24,339-341$

24. Zondag, H.A. and van Boetzelaar, G.L. (1960) Determination of protein in cerebrospinal fluid; sources of errot in the Lowry method. Clin. Chen. Acta, 5, 155-15.6

22. Petersion, G.L. (1977) A simplification of the protein assay method of Lowry et a1. Anal. BLochem. 83, 346-356

23. Neurath, A.R. (1966) Interference of sodium ethylenediaminetetracetate in the determination of proteins and its Qlimination. Experientia 22,290 
24. Bennec, $\mathbb{T} . \mathbb{P},(1967)$ Methe filtration for determining protein in the presence of anterfering substances. Wature $213,1131-1132$

25. Doetsch, $K$, and Gadsden, R. Al. (1975) Deteralnation of urinary total protein by use of gel filcration and a modified biuret method. C11n. Chem. $21,778-781$

20. Hoss, E. and Schatz, G. (1973) ks:say of protein in the presence of high concentrations of stlfhydryl compounds. Anal. Biochem. 54, $304-306$

27. Henry, R.J., Camnon, D.C. and Hinkelman, J.W. (1974) Clinical Chemistry, principles and techniques, pag. 416 (Harper Row, New York)

28. Schultze, H.E. and Heremans, J.E. (1966) Molecular biology of human proteins, No1, I, pag. 115, pag. 173-235 (Elsevier, Austerdant) 
ahapter

PLASMA PROTEINS

IN MAMMARY TUMOUR CYTOSOLS

\section{SUMMARY}

The determination of serum albumin in manary tumour cytosols is described. Both radial immundiffusion assay and curbidirnecric amalys is can be used. It is concluded that in the calculation of oestrogen receptor concentration the protein content of the cytosols must be corrected for the presence of serum proteins.

\section{INTRODUCTION}

In the expression of oestrogen receptor concentration as binding capacity in fmols of oestrogen per mg protein in cytosols prepared from tissues, a number of difficulties are involved. These have been described in detail in a study on protein determination in mamary tnmour cytosols (chapter 5). However, once a suitable method for the protein determination in the concerned cytosols has been found, another problem is that not all protein in the cycosol is really tumour protein. It can easily be understood that in most tumours a certain contanination with blood is present. Although this is sometimes very gmall it leads to an eldevted protein content based on the presence of plasma proteins in the cytosol. It appear that the method of preparation of the cytosal does not fully alininate plasma protein. Sometimes fairly large amounts (even up to $40 \%$ ) of serum albumin are reported to be found in tumour cytosols (1). 
A cortection for these non-tissue proteins can be made by perforraing specific deternation of contuminant plasma proteins by imbunochenical methods. For this reason the serum alsumin content was determined ingunochemically using a so-called monospecific albumin antiserus. Several procedures can be used for this determination which have to be compared and should lead to the same rexults.

In this study radial indunodifeusion (2) has been compared with a rapid irmunochemical albuin deterationation performed by centrifugal analysis $(z)$.

\section{MATERIALS AND METHOOS}

1. Hutan serum albumin (H.S.A.) standards. Purified kuman albumin (Behring Werke AG, Marburg/Lahn, Gemany; lot ar. 55.263) was dissolved in water to make standard solutions of the appropriate concentrations.

2. Anti-H.S.A. serum (LN rabbit antiserum to human albumin, Biehring Werke, lot nr. A $3903 \mathrm{~F}$ ) was abtained comercially and had a tiltre of $2.0 \mathrm{~g} / 1$. This titre is expressed as the quantity in grams of the particular protein antigen (here: human serum albuming precipitated by 1 litre of antiserum in the single radial immuradif fusion test $(4)$.

3. Radial immunodiffusion (R.T.D.) determinations were done using commercially available agarose plates (LC-Partigen, Behring Werke). H.S.A. standards (albumin-LC standards, Behring Werke) were used with concentrations of $0.076 \mathrm{~g} / 1,0.193 \mathrm{~g} / \mathrm{L}$ and $0.390 \mathrm{~g} / 1$. Linear relations were always obtained between precipitations area surfaces and concentrations.

Another series of $\mathbb{R}$. I.D. experiments was performed using agarose plates prepared in the laboratory: To $5 \mathrm{ml}$ of $a 2 \%(w / v)$ agarose (Agarase L, Behring Werke, lot nr. 252007 B) solution in water 
table $6-1$

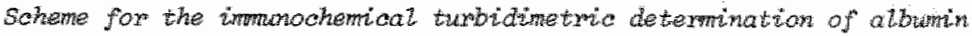
In cytosols (dituted $1: 25$ ) by centritugat analystos.

\begin{tabular}{|c|c|c|}
\hline temperature & 30 & $a_{\mathrm{C}}$ \\
\hline type of analysis ${ }^{*}$ & 7 & \\
\hline wave length & 340 & man \\
\hline sample volume & 50 & 11 \\
\hline diluent valume $\left(\mathrm{H}_{2} \mathrm{O}\right)$ & 50 & 1 \\
\hline reagent volume (PEG in buffer) & 200 & $\mu 1$ \\
\hline incubation time & 30 & $\sec$ \\
\hline starting reagent volume (antiserum) & so & $\uplus 1$ \\
\hline time interval (reaction time) & 600 & sec \\
\hline alburain standard 1 & 0.3 & $\mathrm{mg} / \mathrm{sal}$ \\
\hline albumin standard 2 & 1.0 & $\mathrm{mg} / \mathrm{Al}$ \\
\hline albumin standard 3 & 2.0 & $\mathrm{mg} / \mathrm{ml}$ \\
\hline
\end{tabular}

* machine cose indicating a method with blank subtraction (Cobas Bio Amalyzer, Hoffmann La Roche)

were added $0.5 \mathrm{ml}$ of antiserum (rabbit anti-H.S.A.), $2.2 \mathrm{ml}$ of a $15 \%(w / v)$ solution of polyethylene glycol-6000 and $2.3 \mathrm{ml}$ of a barbital-acetate buffer, pH 8.2. This buffer was prepared by dissolving 8.92 garbical sodium $(5,5$ diethylbarbituric acid sodium salt) with $5.89 \mathrm{~g}$ sodiun acetate trihydrate in water, adding about $120 \mathrm{ml} 0.1 \mathrm{Mydrochloric}$ acid and adjugting to $\mathrm{pH} 8.2$ whereupon water was added to make up a cotal volume of $100 \mathrm{ml}$. Final data for the agarose plates: agarose 1. antigerum titre $0.1 / 1$ (dilution $1: 20$ ), PEG-6000 concentration $3.3 \%$, buffer molaricy for sodium barbital $0.022 \mathrm{M}$ and for sodium acetate 0.036 M. pH 8.2, ionic strength $\mu=0.05$.

4. Centrifugal turbidimetric analysis was performed using a method 
originally described for imuno globulins ( 3 ) i.e. fixed time analysis with blank subtraction. Cytosolg were diluted with buffer $1: 25$. The description of the procedure is given in table $6-1$. polyethylene glycol (PEG-6000) was added to the reaction mixture in order to accelerate formation and insolubilisation of the alburin-anti. H.S.A. complex. H.S.A. standards were prepared with concentrations of $0.5 \mathrm{~g} / 1,1.0 \mathrm{~g} / 1$ and $2.0 \mathrm{~g} / 1$.

5. Immuo electrophoresis das dome in agar gel (2\% w/w) (Agar purum, Behring Werke, lot $\mathrm{nr}, 2103$ A) in the barbital/acetate buffer already described.

The method was based on a technique by Grabar and Williams $(5)$. The same antigeruri was used as above.

\section{RESHLTS}

Comparison of the results of determination of human serum albumin in anmary tumour cytosals with the techniques described did not show significant differences for freshly prepared cytosols (figure b-1). In cytiosols which had been kept at $4^{\circ} \mathrm{C}$ for at least three monchs ("aged" cytosols) the values found by turbidimetric analysis were also equal to those resulting from single radial immunodiffusion (figure 6-2). In this case, however, a double ring was observed in the later procedure where the larger zone was washed out with physiological saline solution. This phenomenon was observed both in commercially agarose plates (Partigen ${ }^{n}-L C$ ) and in plates prepared in laboratory. The latter plates contained PEG-6000 (see Materials and Methods action) in order to create circumstances as similar as possible to the reaction mixture in turbidimetric analysis. The presence of $P E G$, however, did not enhance these phemomea $(6 a b 20-2)$. Pertups ageing of the cycosols had caused some proteins to precipitate aspecifically in the agarose without becoming irreversible insoluble.

For further investigation inmunoelectrophoresis was performed. Sometimes double precipitation lines voor H.S.A. were observed both 
tigure $6-1$

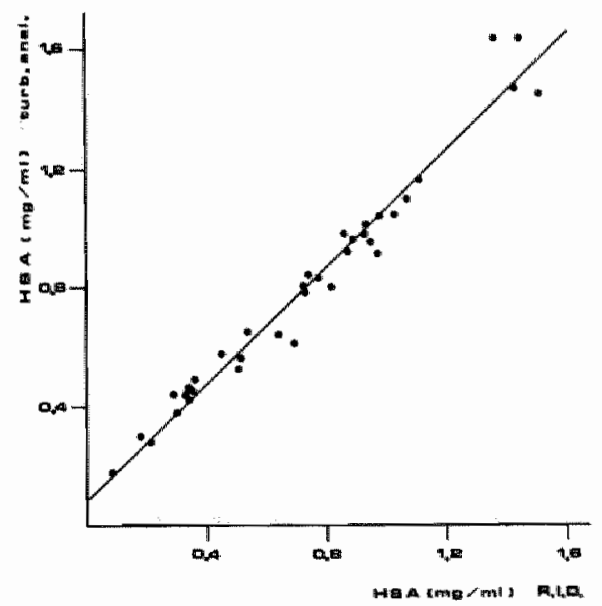

Correlation of the radial inmunodiffusion assay (R.I.D.) and turbidimetric analysis of human serm atbumin in fresh momaxy tumour cytosals, $\mathrm{n}=36, \mathrm{x}=0.986$ (figure $6-1$ ) and in "aged aytosols, $=25, \quad n=0.993$ (figure $6-2)$.

figure $6-2$

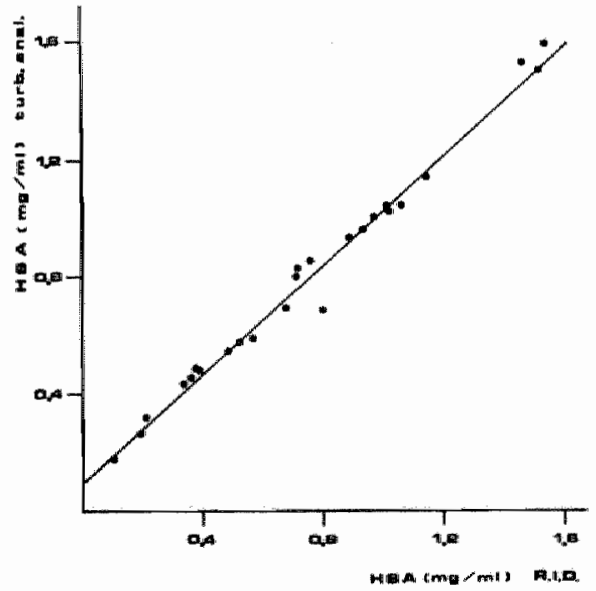


able $6=-2$

Conparison of valueg (mg/mly obtatred in atbumbin detarminations, in

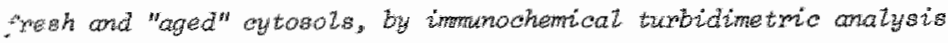
(ITA) and by nadiat inmunodf fusion without (RID) and with (RIO/EEG) addition of polyethylene gityoot.

\begin{tabular}{|l|l|l|l|l|l|l|}
\hline cytosol & $y$ & a & a & b & r & $n$ \\
\hline Eresh & ITA & RID & 0.98 & 0.09 & 0.986 & 36 \\
Eresh & ITA & RID/PEG & 0.92 & 0.10 & 0.988 & 19 \\
Eresh & RTD/PEO & RID & 1.06 & 0 & 0.988 & 19 \\
\hline "aged" & ITA & RID & 0.91 & 0.11 & 0.993 & 25 \\
"aged" & ITA & RID/TEG & 1.00 & 0.08 & 0.995 & 19 \\
"aged" & RTD/PEG & RID & 0.92 & 0.03 & 0.993 & 17 \\
\hline
\end{tabular}

- between all methods there is linear correlation characterized by the equation $y=a x+b$

- the number of paired diata $(n)$ and the linear correlation coefficient ( $x)$ are also giwen

in fresth and "aged" cytosols. These, however, consisted of insoluble material which did not disappear during the washing and subsequent dying procedures. Apparently the cytosols contained albumin-like proteins or perhaps partly degraded serum alburain which might have arisen during the cytosol preparation procedure. Moreover, immunoelectrophoresis of tumour cytosols using palywalent anti human serum antiserum demonstrated the presence of a large number of serum proteins in the cytosol (figure $b-3$ ).

It should also be noted that in cytosols from calf uterus a remarkably high albumin content was found. These cytosols are widely used in oestrogen receptor analysis as positive controls and were subjected to the same experiments and analyses as the human tunour cytosols, It appeared that the commercially obtained monovalent 


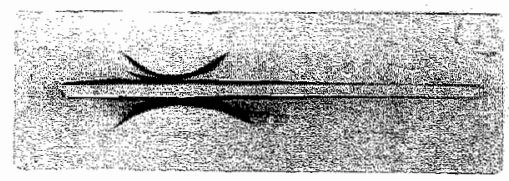

A

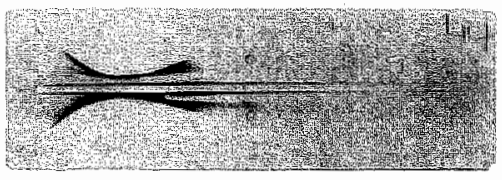

$\mathbf{B}$

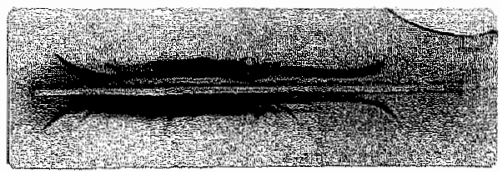

$\mathbf{c}$

figure $8-3$

Immunoelectrophoresis of mammaxy tumour cytosols.

A upper pattem: fresh cytosol; centre well: monospecifio anti H.S.A. antisemm; lower pattern: pooled hwon semom.

$B$ upper pattem: "aged" cytosol;

centre well: monospecifico onti H.S.A. antigerum;

tower patterm: pooled hwon serwm.

c upper pattem: fresh cytosol;

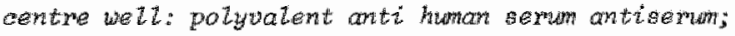
tower pattern: pocked humen semum. 


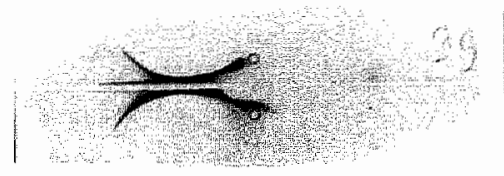

A

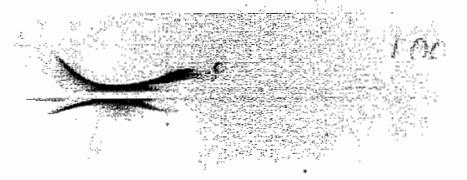

$\mathbf{B}$

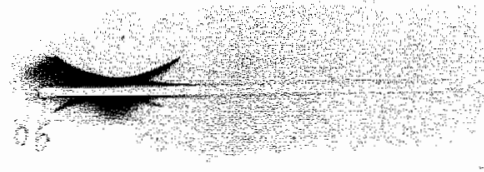

C

figure 6-4

Imomanoetectrophorestia of calf litems cytosol and other proteins with monospecific anti H.S.A. serum (cemtre welt in alt patterms).

A uxper pattem: calf uterus oytosol; lower pattem: poozed human serwass.

B upper pattern: oatf utheras oytosol; lower pattern: bovine semun albumin.

c appero pattem: alf litems cytosol; Lower pattern." equine semun. 
rabbit antiserum against human serum albumin cross reached with bovine serum albumin as was demonstrated in immunoelectrophores is (figure 6-4). With this antiserum equime serum also yielded cross reactions. The antiserum apparently was not species-specific.

\section{DISCUSSION}

From the experiments described it is clear that tumour cytosols contain albumin and other serum proteins in addition to tissue proteins. This is not surprising and is in accordance with daca reported by others ( 1 ).

As no significant differences were found between the radial immunoassy and abumin determination by immuochemical centrifugal analysis, the lacter procedure is recommended on account of its good feasibility in the routine laboratory and the short time required for the analysis. The consequence of this finding is that a correction must be made for non tumour protein concentration. This may well result in a higher incidence of receptor positive tumours than hitherto found. Another consequence is that the criterion used for the distinction between "positive" and "negative" tumours has to be reconsidered.

Definitions of positive and negative may vary $(6,7,8)$ between authors. In our laboratory tumours having an oestrogen receptor concentration under 3 fmol/mg protein are considered megative whilst those over $9 \mathrm{fmol} / \mathrm{mg}$ protein belong to positive tissues. There is certainly a "grey zone" which in practice, however, appears to be of little significance when good corrections for non-specific binding of oestradiol are inherent in the detemination procedure.

The selectivity of commercially available antisera against human serum albumin is another aspect which needs to be reconsidered. Apparently ther is a high degree of cross reactivity in these antisera towards albumin of manmalian origin, i..e. man, cow and horse. This simplifies the determination of the oestrogen receptor 
concentration in the commonly used calf uterus cytosol (positive controll) and explains why in gene positive controls only a weak oestrogen binding is found, i.e. when a considerable part of the protein in these cytosols consists of bovine serum proteins. No crosg reaction was seen whth serum proteins other than alburin. This suggests the hypothesis that the probability of reaction wh thuman tumour tissue protein may be very low or absent. If this is true the possibility is introduced of malking due correction for the presence of serum proteins in the cytosol.

The proposition $(9)$ is supported that the cytosol protein concentration should be corrected by subtraction of the amount of the serum protein calculated from the albumin estimated irmumologically. This serum protein calculation is then based on the assurmtion that roughly $60 \%$ of the protein content of serum consists of albumin.

From the present study it is concluded that in the deternination of the procein concentration in tumour cytosols a correction has co be made by subtracting serum protein estimated as 1.7 tines the albumin concentration. This corrected tumour pratein content in the cytosol is to be used for the calculation of oestrogen receptor concentration. New attention must be paid to the establishment of criteria for positivity and negativity of oestrogen receptor in Eissures.

\section{REFERENCES}

1. Kute, T.E., Huske, M.S., Shore, A. and Rhyne, A.L. (1980) Improvements in steroid receptor assays including rapid computer analysis of data. Anal. Biochem. 103, 272-279

3. Mancini, G., Carbonara, A.O. and Herenans, J.E. (1965) Immunochemical quantitation of antigens by single radial inmunodiffusion. Immunochemistry $2,235-254$

S. Mare11, G.J. and Mrombacher, P.J. (1981) Rapid and sensitive 
immunochemical determination of immunoglobulins by centrifugal analysis. J. Clin. Chem. Clin. Blochen. 19,67-70

4. Becker, W. (1969) Determination of antisera titres using the single radial immunodiffusion method. Inmunochemistry 6,539-546

5. Grabar, P. and Williams C.A. (1953) Mêthode permettant I"etude conjugêe des propriétés electrophorétiques et immunachimiques d'un mélange de protêines. Application au sérum sanguin. Bioch. Bioph. Acta $10,193-194$

6. King, R.J.B. (1975) Clinical relevance of steroü-receptor measurements in tumours. Cancer Treat. Rev. 2, $273-293$

7. Witliff, J.L. and Savlov, E..D. (1978) Biochenical basis for the selection of hormonal manipulation in the patient with breast carcinoma. Int. J. Radiat. Oncol. Biol. Phys , 4, 463-467

Q. MeGuire, W.L., Horwitz, K.B., Zava, D.T., Garola, R.E. and Chamess, G.C. (1978) Hormones in breast cancer: up date 1978. Metabolism $27,487-501$

9. Wagner, R.K. (1978) Extracellular and intracellular steroid binding proteins. Acta Endocr. (Kbh.) supp1. 218, 25 
chopterg 7

\section{INFLUENCE OF BUFFER COMPOSITION, TEMPERATURE AND TUMOUR TISSUE ON THE PH OF CYTOSOLS}

\section{SUMMARY}

The influences of buffer composition, temperature of pH adjutment of the buffer, tumour tissue protein and lactate content on the pH of breast cancer cytosols has been studied. Moreover, the results obtained by aestrogen receptor determination in cytosols prepared with different buffers have been compared. The conclusion fron these investigations was that standardization of reaction conditions and the use of $0.05-0.1 \mathrm{M}$ TED-buffer should be reconmended.

INTRODUCTIION

Many different buffers have been used in the preparation of tumour tilssue cytosols and the subsequent deternination of steroid receptor concentration in these cytosols $(1,2,3)$. The problem is even more complicated because the temperature at which the pH of the buffer is adjusted, is often not mentioned. This causes much uncertainty on the actual conditions of the assay as some of the buffers used have an important temprature coefficient.

In the present investigation several parameters concerned with the pll of the reaction mediun have been studied, such as buffer compostion, temperature of initial pH adjustment, protein content of the cytosol and the lactate content of the latter. It is remarkable that information on the lactic acid content of tumour tissues is almost never reported 
tabte $7-1$

Composition of TED buffers and phosphate buffene

\begin{tabular}{|c|c|c|c|c|c|c|c|c|}
\hline ne. & $\operatorname{trig}-\mathrm{HCX}$ & EDTA & 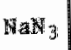 & DTT & $\mathrm{eg} 1 \mathrm{yc}$ & glyc & pH 7.5 adj. & $\mathrm{pH} 7.9 \mathrm{adj}$ \\
\hline 1 & 10 & 1 & 3 & 0.5 & - & - & $0^{\circ}$ & - \\
\hline 2 & 10 & 1 & 3 & 0.5 & - & - & $25^{\circ}$ & - \\
\hline 3 & 10 & 1 & 3 & 0.5 & 10 & $10 \%$ & $0^{\circ}$ & - \\
\hline 4 & 10 & 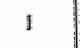 & 3 & 0.5 & 10 & $10 \%$ & $25^{\circ}$ & - \\
\hline 5 & 50 & a & 3 & 0.5 & - & - & - & $0^{\circ}$ \\
\hline 6 & 100 & 1 & 3 & 0.5 & - & - & - & $0^{\circ}$ \\
\hline 7 & 200 & 1 & 3 & 0.5 & - & - & - & $0^{\circ}$ \\
\hline & phosph. & EDTA & $\mathrm{NaN}_{3}$ & & tglyc & glye & pH 7.5 adj. & \\
\hline 8 & 10 & 4.5 & 3 & & 10 & - & $0^{\circ}$ & - \\
\hline 9 & 10 & 1.5 & 3 & & 10 & - & $25^{\circ}$ & - \\
\hline 10 & 10 & 1.5 & 3 & & 10 & $10 z$ & $0^{\circ}$ & - \\
\hline$n$ & 10 & 1.5 & 3 & & 10 & $10 \%$ & $25^{\circ}$ & - \\
\hline
\end{tabular}

- all concentrations are given in mol/1 (except glycerol conc.)

- glyc: glyceroll concentration in \% volume/volume

- tglyc : a-monothioglycerol

- phosph. : phosphate buffers are made by mixing appropriate volumes of $10 \mathrm{mH}$ solutions of $\mathrm{KH}_{2} \mathrm{PO}_{4}$ and $\mathrm{K}_{2} \mathrm{HPO}_{4}$

- pli was adjusted to the predetermined value at the temperature mentioned in the last columns

in this context although lactic acid production in malignant tumours can be quite important and rather weak buffers are used in the assays of steroid receptor protein concentration. The use of weak buffers prevents the influence of increased ionic strength on the molecular form of receptor but gives less plit stability. 


\section{MATERIALS}

- buffers studied in this investigation have been listed in tables ?-1. Most of these have been used by different authors, those containing glycerol being especially recommended for the progesterone receptor determination $(1,2)$.

- lyophilised horse serum (Seronornin, Nyegard, Oslo/Norway)

- fresh human serum obtained from bllood which was left at ambient temperature for clotting during one hour

- all other chemicals used were analytical grade quality

- pH meter (Research pH meter PHM 64; Radioneter, Copenhagen/Dentark)

\section{CYTOSOLS}

The cytosols were prepared as follows:

$500-600 \mathrm{mg}$ of frozen human breagt tumour tissue or call uterus tissue were pulverised in a stainless steel mortar imersed in liquid nitrogen. The abtained frozen rough powder was then vitrated during 45 seconds three times at $50 \mathrm{~Hz}$ in a teflon vial with a micro dismembrator (Braun, Melsungen/Germany). The resulting frozen fine powder was transferred to a 5 ml polypropylene ultracentrifugation tube whereupon $3 \mathrm{ml}$ buffer (generally TED buffer na. 2 in table $7-1)$, at $0^{\circ}$ were added. The tube was stoppered and vibrated for another two minutes with the microdisnembrator. The volume was made up with the same buffer to $5 \mathrm{ml}$ and the contents of the tube thoroughly mixed. After 30 minutes ultracentrifugation ( $100,000 \mathrm{~g} ; 1^{\circ}$ ) the tube was laterally punctured and the whermatant collected avoiding lipid comtamination from the surface of the liquid.

Following this procedure cytosols were obtained with protein content within $2-4 \mathrm{mg} / \mathrm{ml}$, in accordance with the cytosols ganerally used in our laboratory for steroid receptor determination. 


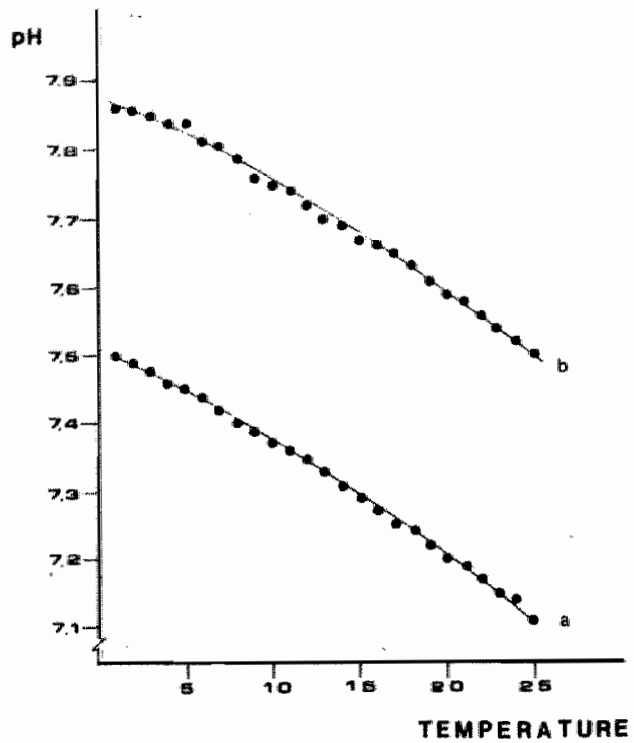

figure 7-1

Influence of temperatume on $I E D$ buffers of twis buffers containing EDTA and DTT (dithiothreitol) I.

a : buffer adjusted at pH 7.5 at $0^{0}$ ( table 7-1; buffer rr.1)

b : buffer adiusted at pH 7.5 at $25^{\circ}$ (table 7-1; buffer n. 2 )

- buffem were heated and cooled with temperature changes of $0.3^{\circ} /$ minute

METHODS

Lackate determination. The lactic acid content of $0.5 \mathrm{ml}$ of the samples was deterained enzymatically wh th lactate dehydrogenase. A lactate calibration solution ( $1.0 \mathrm{M}$ : Boehringer, Mannheim/Germany y wa used to prepare standard solutions of lactic acid. NaDH absicrbance was read at 340 mon. 


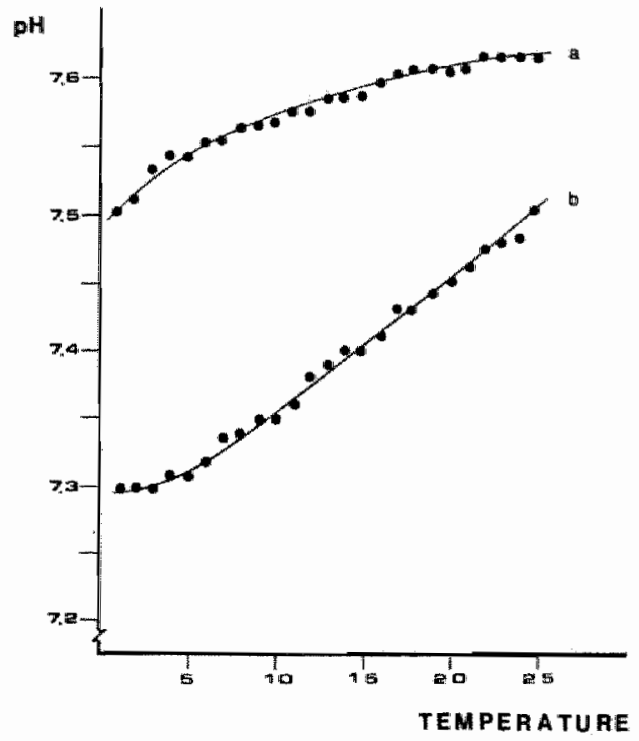

figure $7-2$

Influence of temperature on phosphate buffers.

a : buffex adiusted at pH 7.5 at $0^{\circ}$ (table $7-1$; buffer ra. 8 )

b : buffer adjusted at pl 7.5 at $25^{\circ}$ ( table $7-1 ;$ buffer nr.9)

- buffers were heated and cooled with temperature changes $0.3^{\circ} /$ minute

Protein determingtion. Protein was determined by a biuret method by centrifugal analysis (the thesis; chaptex is).

Serum albumin was determined by radial immono difusion in Partigen ${ }^{p}$ LC plates (Behring Werke, Marburg/Germany).

pH measurements were performed as follows:

A buffer sample was placed in $250 \mathrm{ml}$ beaker and prectsion thermometer and the combination electrode of the pH meter were inmersed. The 
beaket was placed in a wher bath. The contents of this bath and the sample were both continuously stirred with a magnetic stirrer. Increase or decrease of temperature was adjusted at $0.3^{\circ}$ per minute. For each sample the pHit variations were measured twice, i,e. during increasing and during decreasing temperature ower the range $0^{\circ}$ to $25^{\circ}$ vice versa.

\section{RESULTS}

The pH values of TED buffers with the concentrations as indicated for the determination of oestrogen receptors (generally 0.01 M) appeared to be cansiderably temperature dependent. Increasing the temperature provoked pH decrease $(f i g .7-1)$. The temperature coefficient for the TED buffers was 0.016 pH units per degree centigrade.

The pH values of $0.01 \mathrm{M}$ phosphate buffers changed in opposite direction with temperature vaxiation ( fig. $7-2)$. A positive temperature coefficient of $0.008-0.004 \mathrm{pH}$ units per degree centigrade was measured, the variation being dependent on the initially adjusted pll and temperature.

In both types of buffers glycerol addition ( $10 \%$ volume/volume) had no influence on the $\mathrm{pH}$ values. This addition is often recommended for the preparation of cytosills for the determination of progesterone receptor protein.

According to generally used procedures cytasols for the determination of oestrogen receptors were prepared with TED buffer ( buffer nr. 2 ; table $7-1$ ). The pH of the cytosolis was measured at the working temperature $0^{\circ}$. The diversity of results of pli measurements is illustrated in figure $7-3$. Mean and median $\mathrm{pH}$ value was 7.65 ; range 6.4 to 8.2

The lactate concentration in the cytosols has also been determined. No direct relation with the pH values could be established. Concentrations ranged from 0.08 to 3.2 mol $/ 1$ (fig. 7-4). Mean concentration 1.06 moll 1 ; mediam concentration $0.8 \mathrm{mmol} / 1$.

In the cytosols that were studied not much influence of the protein 

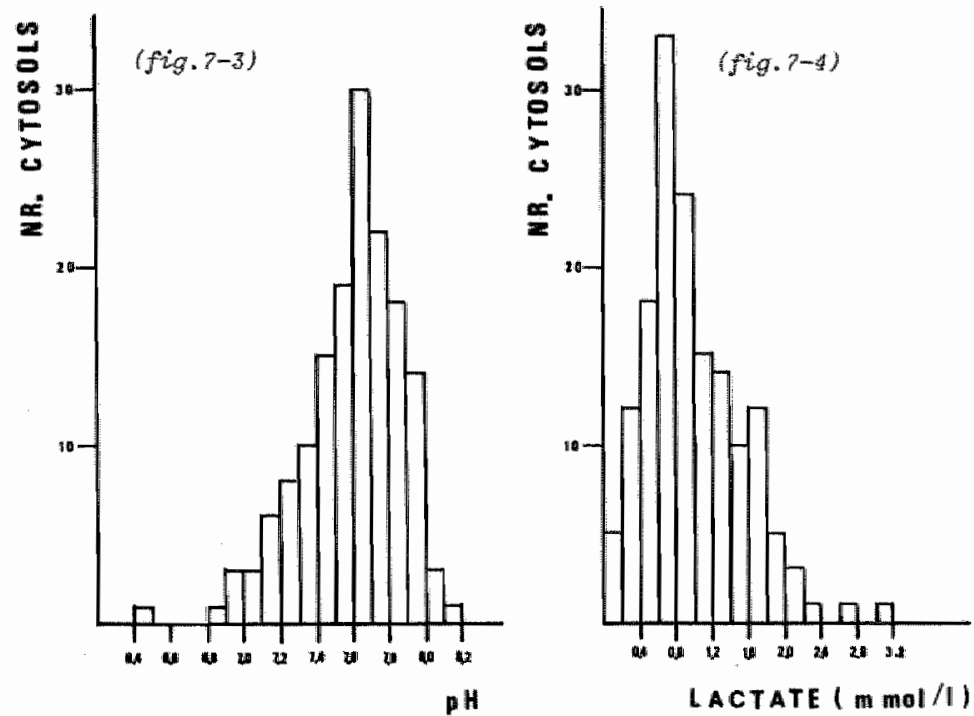

pH

LACTATE ( $\mathrm{mmol} / 1)$

figume 7-3 pil vatues of mamary tunow cytosots prepared with TEW buffer (buffer nr. 2; table 7-1)

figume 7-4 Iactate conoentration in mannary tumour aytosols prepared with TED Buffer ( Buffer no. 2 ; table $7-1$ )

concentration on the $\mathrm{pH}$ could be observed. These concentrations varied between $2.4 \mathrm{mg} / \mathrm{ml}$ and $4.0 \mathrm{mg} / \mathrm{ml}$. This is not surprising because in the preparation of cytosols standardization of the wet tistse weight per volume buffer is respected.

Studies on the influence of addition of lactic acid or/and protelnt ko TED buffers were also performed. Values of pH found after vary ing amounts of lactic acid added to TED buffers with different concentration of tris (buffers nrs $2,5,6$ and 7 ; table $7-7$ ) are given in figure $7-5$. All buffers contained a same amount of added equine serum proteins. This was adted in order to obtain protein containing buffers comparable 


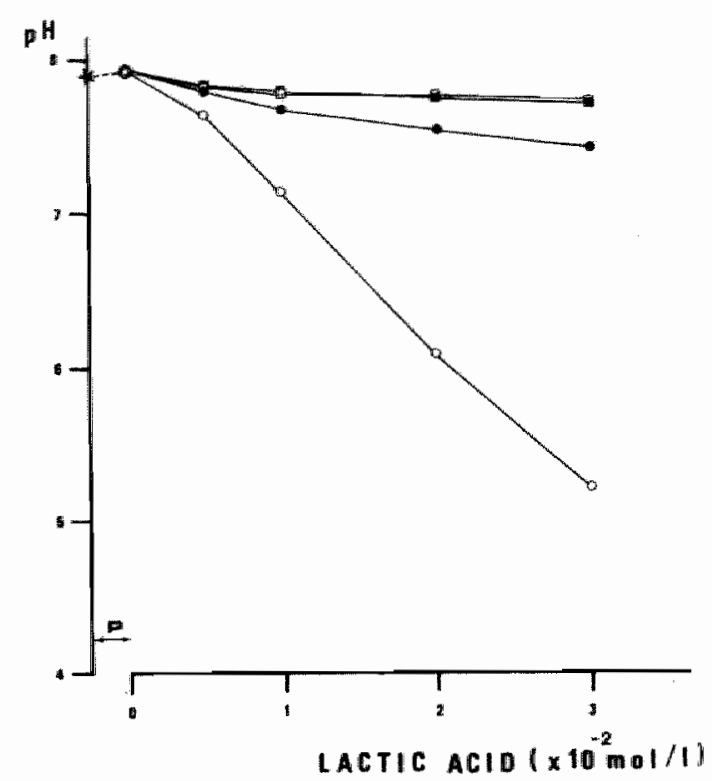

figure $7-5$

Influence of addition of increasing anownts of lactid acid on the pH of TED buffers after addition of a constont amount of equine semm protein

- O- reD buffer 0.01 M tris (buffer nr.2; table 7-1)

- - TED buffer 0.05 $\mathrm{N}$ tris ( buffer mo.5: table 7-1)

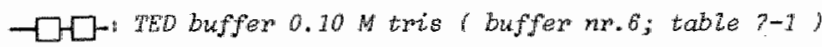

-HA : TED buffer 0.20 M tris ( buffer nr.?; tabte 7-1)

* $\mathrm{pH} 7.9$ adjusted at $0^{\circ}$ before protein adatition for all four buffers

P addition of equine serw protern to a final concentration of $2 \mathrm{~g} / \mathrm{t}$ in ecolh buffer

0. ph of alt buffers after addition of protein ati ist values were measured at $\theta^{\circ}$ 


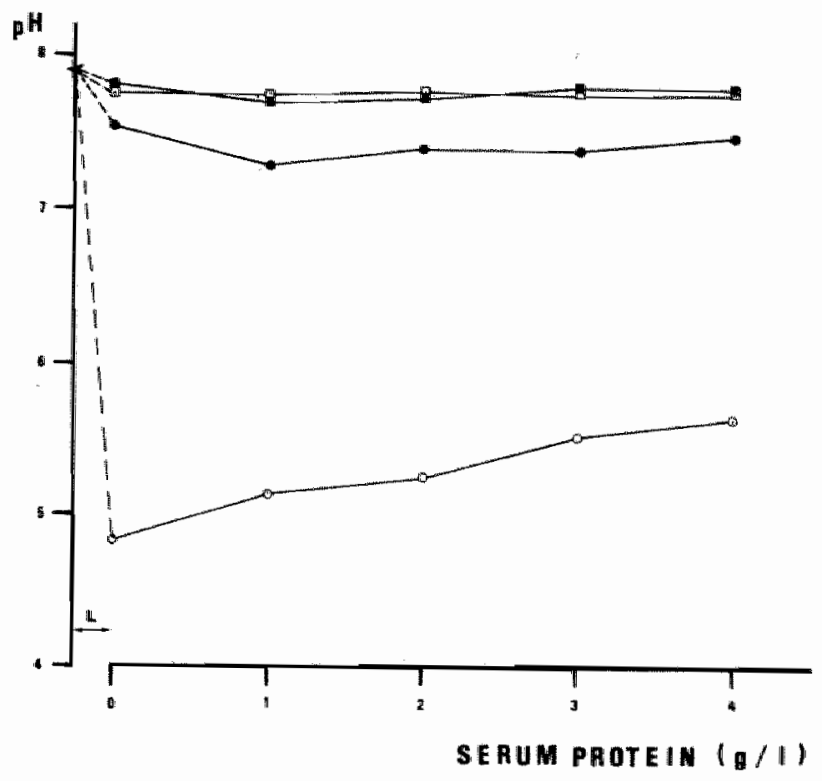

Ligume $7-6$

Irfluenae of adation of increasing conowts of equine semam protein on the ph of TED buffers after addition of a constant amount of lactio acid; $p H$ values were alt measured at $0^{\circ}$

- buffer concuntrations as given in figure 7-5

* : DH 7.9 adjusted at $0^{\circ}$ for all buffers before lactio acid addition

L: addition of lactic acid to a final conoentration of $0.0026 \mathrm{M}$ in each buffer

to cytosols with the lowest protein concentration $(2$ atg/tal 1$)$. The addition of this anount of protein only slightly changed the pll of the buffers which had initially been adjusted at 7.9 at $0^{0}$. As could be expected the greatest pH change was observed in the buffer with the lowest tris concentration. 
In comparable series of experiments increasing anounts of protein (a concentrated solution of lyophlilized blood serum) were added to TED buffers after addition of a constant amount or lactic acid. Not: surprisingly the pH decrease was strongest in the least concentrated buffer. This decrease could only partially be restored by adding protein in increasing amounts. More concentrated buffers were less influenced $(f i g .7-6)$. Both human and equine serum proteins were used; similar results were obtained.

A last series of experiments have been the determinations of oestrogen receptors in cytosols prepared in different buffers (nrs $2,3,6$ and 7 ; table $7-1$ ). The same calf uterus tissue was used for the preparation of the cytosols. Regults are given in table $7-2$.

\section{DISCUSS10N}

A number of variable factors in the reaction circumstances of the determination of oestrogen receptor concentration in tissue cytosols have been studied. Considerable influence of the temperature of initial pH adjustment on the final $\mathrm{pH}$ in the reaction medium was found. This was equally true for TBD buffers and for phosphate buffers. It seems to be indispensable therefore, that accurate information be given on the preparation of the buffers and the cytosols including temperature of pll adjustment. And this although it has been reported that the cytosol receptor protein activity is insensitive to $\mathrm{pH}$ changes within the range 7 to 9 ( 4 ). However, disappointing results found in interlaboratory comparative studieg ( 5 ) suggest at least strict standardization of reaction conditions when improvement of interlabotatory correlation is aimed at.

A considerable influence of tumour tissue constituents on the finall pH of the reaction medium in TED buffer was also found. The pH of the TED buffers significantly changed upon lactic acid addition. This pH decrease was somewhat counteracted by protein. However, the use of the 
table $7-2$

Oestrogen neceptor determination of alf uteris oytosol iw different TED buffers

\begin{tabular}{|c|c|c|c|c|c|c|c|}
\hline $\begin{array}{c}\text { samp le } \\
\text { nr. }\end{array}$ & $\begin{array}{c}\text { wet tissuse } \\
\text { weight }\end{array}$ & $\begin{array}{c}\text { tris } \\
\text { conc. }\end{array}$ & $\begin{array}{c}\text { pH of } \\
\text { cytosol }\end{array}$ & $\begin{array}{c}\text { lactate } \\
\text { conc. }\end{array}$ & $\begin{array}{c}\text { protein } \\
\text { conc. }\end{array}$ & E.R. & $\mathrm{K}_{\mathrm{d}} \cdot 10^{-9}$ \\
\hline 1 & 510 & 0.01 & 7.61 & 1.17 & 2.25 & 436 & 0.32 \\
\hline 2 & 502 & 0.05 & 7.80 & 1.10 & 2.27 & 493 & 0.37 \\
\hline 3 & 517 & 0.10 & 7.85 & 1.24 & 2.32 & 422 & 0.31 \\
\hline 4 & 508 & 0.20 & 7.86 & 1.45 & 2.55 & 424 & 0.47 \\
\hline
\end{tabular}

- the tissue (mg wet weight) is processed in 5 ml buffer

- tris concentration in the TED buffers is given in mol/l

- lactate concentration in the cytosols is given in mol/1

- protein concentration in the cytosols is given in mg/m1

- oestrogen receptor concentration (E.R.) is given in ${ }^{2}$ mol/mg protein

- the pll of the buffers was adjusted at 7.9 at $0^{\circ}$

(buffers are specifled in table $7-1$, nrs $2,5,6$ and 7 )

0.01 TED buffer might result in considerably depressed ph walues, this being especially possible when the protein concentration in the cytasol is low and the lactate concentration is relatively high. In order to avoid too low results in the oestrogen receptor determination it seams advisable to recommend the use of more concentrated buffers, e.g. the 0.05 or even the $0.100 \mathrm{M}$ TED buffers. This i.s even more mecessary as the optinum for oestrogen receptor activity is pH $8(6)$.

No direct relation between phepression and lactic acid content ith the cytosols was found. Apparently other constituents from the tumour tissue also contribute to the final cytosol pH. 
Finally the influence of buffer molarity on the result of the oestrogen receptor determination was studied. Although some variations were found no absolute preference for any of the four different buffer eould be eatabilished. This could perhaps be explained by the fact that the low protein content af the cytosols prevents a number of non-specific binding reactions and the inherent complications in the calculation of the results ( 7 ). Another reason might have been the fact that this was investigated in calt uterus cytosols; adthough significant lactate concentrations were found, the composition of the tissue is still different from mamary tumour of human origin. A problem in many of the studies as described. here is that quite often the human breast cancer tissue samples wich were submitted for investigation were quite small.

\section{REFERENCES}

1. E.O.R.T.C. Breast Cancer Cooperative Group (1979) Standards for the assessment of hormone sensitivity in human breast cancer. Report of the second workshop on March $16 / 17-1979$ at the Antoni van LeeuwemhoekHuis, Amsterdam

2. Pichon, M.F. and Milgrom, E. (1977) Characterization and assay of progesterone receptor in human mammary carcinona. Canc. Res. 37, 464-471

3. Bayard, F., Damilano, S., Robel, P. and Baulieu, E.E. (1978) Cytoplasmic and nuclear estradiol and progesterone receptors in human endometrium. J.clin.endocr.metab. 46, 635-648

4. Chester, 2., Feherty, P., Kellie, A.E. and Ralphs; D.M.L. (1975) Estrogen receptor in primary breast tumors in relation to the stage and progression of the disease. Pag. 157-174 in: Mc Guire, w.L. (Ed,) Estrogen Receptors in Human Breast Cancer (Raven Press, N.Y.)

5. Koendars, A. and Benrad, Th.J. (1980) Kwalliteltscontrole van steroidhormoonreceptar metingen. Tijdschr. Nad, Ver. Klin. Cherte $6.185-187$ 
6. Hahne1, R. and Vivian, A.B. (1975) Biochemical and clinical experience with the estimation of estrogen receptors in human breast carcinoma. Pag. 205 - 235 im: Mc Guite, W. I. (Ed.)

Estrogen Receptors in Human Breast Cancer (Raven Press, N.Y.)

7. Ralet, Ph.G.F.A.H., Gijzen, A.H.J. and Brombacher, P.J. (1981) unpublished results 
chapter

CHARACTERISATIOH OF OESTROGEN

RECEPTOR PROTEINS

SUMMARY

For the characterisation of oestrogen receptor proteins a number of techniques have been used: gel filltration on sephadex ${ }^{R}-150$ and on Sephacryl ${ }^{R} \mathrm{~S}-300$, sucrose density gradient ultracentrifugation and polyacrylaide gel electophoresis. The molecular weight class of the receptor proteins was estimated. In the cytosol both specific and non-specific binding proteins were detected and distingulshed. Moreover, wo forms of receptor proteins were demonstrated, both being able to bind labelled oestradjol specifically. On account of distinct fundamental differences in the techniques, it could hardly be expected that results would bo identical in the three procedures. Receptor proteins of "low" molecular weight were invariably found and aggregation phenomena were always observed. It is highly probably that characterigation off native receptor proteins cannot be performed by the ustal technical procedures because of inherent influences of the detection methods on the structure of these receptors.

INTRODUCT ION

An interesting aspect of the determination of steroid homone binding in cytosols prepared from human tissue is the characterisation of the binding proteins. A number of actenpts lave 
been made in this field using techniques suitable for the separation and identification of macromolecules, such as gel filtration $(I, 2)$ electrophores is (3) and density gxadient centrifugation (4). These analytical procedures provide information on the proteins inwolved whilst separtion between free hormones and sterotd protein compleyes is also accomplished. Binding phenomena can thus be studied such as the binding of a particular steroid to one or more proteins in the ame cycosol and the specticity of tracer binding in the presence of a large excess of radio-inert ligand.

The binding of aestradiol to receptor proteins in human mamary tumbur cycosols was studied, in order to gather information on the properties of the binding protejns. This investigation was performed as part of a study of the causes of divergent analyticall results obtained in the routine determination of oestrogen receptor concentrations in different laboratories. This diwergence is annoying as resultes of determinations are important for the decision whether hormonal therapy is to be applied in a specific case or denied because tho success can be expected.

GEL FILTRATION

\section{PREPARATION OF CYTOSOLS FROM HUMAN MAMMARN TUMOUR TISSUE}

Cytosols were prepared as described earlier $(5,6)$. No variations in this procedure were allowed during the present study. This method for cytosol preparation was similar to the one that has been recommanded by the E.O.R.T.C. ( 5 ) and is used in many laboratories.

\section{CHEMIICALS}

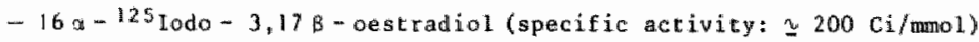
(New England Nuclear) $\left(125 \mathrm{I}-\mathrm{E}_{2}\right)$. 
- Sephadex ${ }^{R}$ G-150 (Pharmacia).

- Siephacry $1^{R}$ s-300 (Pharacia).

- Low and high nolecular weight gel filtration calibration proteins (Pharmacia kits).

- Huan semata albumin (Nordic Pharmaceuticals).

- All other chemicals used were comercial products of analytical grade.

\section{REAGENTS}

- Tris-HCl buffer $10 \mathrm{mM}, \mathrm{pH} 7.5$ at $25^{\circ} \mathrm{C}$, containing 1 mM EDTA, $3 \mathrm{mM} \mathrm{NaN} 3$ and $0.5 \mathrm{mM}$ dithiothreitol (TED buf fer).

\section{SAMPLES}

Human breast cancer tissues were honogenised in TED buffer. In order to obtain cytosol protein concentrations of about $3 \mathrm{mg} / \mathrm{ml}$ tissue samples of about $500-600$ mg wet waight were processed in $5 \mathrm{ml}$ buffer. Tumour cytosol was obtained from pool of five tumours. oestrogen receptor concentration of this cytosol was $174 \mathrm{fmol} / \mathrm{mg}$ protein. Aliquats of cytosol were incubated with labelled aestradiol ( $\left.{ }^{125} \mathrm{I}-\mathrm{E}_{2}\right)$; final concentration $25 \times 10^{-10} \mathrm{M}$ with or without addition of diethylstiboestrol (DES); final concentration $50 \times 10^{-8} \mathrm{M}$ as competitive "cold" $\mathbb{1}$ igand. Incubstion was performed overnight in melting ice, whereupon samples $(1.5-2.0 \mathrm{~m} 1)$ of the reaction mixture were placed in the column.

\section{GEL FILTRATION EQUIPMENT}

$-2 \operatorname{cm}^{2} \times 100 \mathrm{~cm}$ column (Pharmacia $\left.\mathrm{k} 16 / 100\right)$ packed with Sephadex G-150.

$-2 \mathrm{~cm}^{2} \times 100 \mathrm{~cm}$ colum (Pharmacia $\left.\times 1 / 6 / 100\right)$ packed with Sephacry $1^{R}$ 


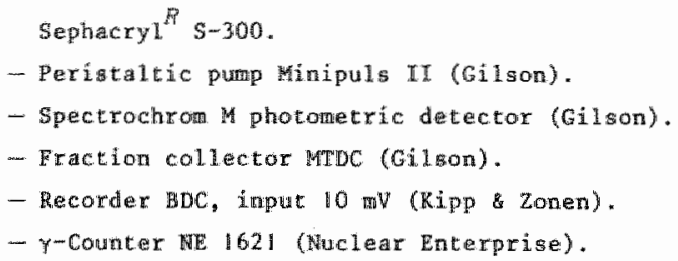

GEL FILTRATION PROCECURE ON SEPHADEX ${ }^{R}$ G-150

Bed dimensions: $2 \mathrm{~cm}^{2} \times 94.5 \mathrm{~cm}$.

Eluent: TED buffer (see reagents).

Gel filtrations: upward flow performed at $2^{\circ} \pm 1^{\circ} \mathrm{C}$.

Sample volume for each run: $2.0 \mathrm{mil}$.

Flow rate: $3.3 \mathrm{mi} \cdot \mathrm{cm}^{-2} \cdot \mathrm{h}^{-1}$.

Fraction wolume: 100 drops $\simeq 1.8 \mathrm{ml}$.

Absorbance of the effluents: continuously monitored at $280 \mathrm{~nm}$.

The analytical procedure is outlined in table $8-1$. For reasions of efficiency results are included in this table.

GEL FITRATION PROCEDURE ON SEPHACRYL ${ }^{R} 5-300$

Bed dimensions: $2 \mathrm{~cm}^{2} \times 89 \mathrm{~cm}$.

Eluent: TEn buffer (see reagents).

Gel filtrations: upward flow pexformed at $2^{\circ} \pm 1^{\circ} \mathrm{c}$.

Sample volume for each run: $1.5 \mathrm{ml}$

Fow rate: $13.2 \mathrm{~m} \cdot 1 \cdot \mathrm{cm}^{-2} \cdot \mathrm{h}^{-1}$.

Fraction wolune: 100 drops $\simeq 1.8 \mathrm{ml}$.

Absorbance of the effluents: continuously monitored at $280 \mathrm{~nm}$.

The analytical procedure is out lined in table $8-2$. For reasons of efficiency results are included in this table. 
table $8-1$

Gea dititration on Sephader $\mathrm{R}-150$.

\begin{tabular}{|c|c|c|c|c|c|}
\hline \multirow[t]{2}{*}{ run } & \multirow[t]{2}{*}{ saxple $2 \mathrm{mil}$} & \multirow{2}{*}{$\begin{array}{l}\text { conc. } \\
\operatorname{mg} / \text { m } 1\end{array}$} & \multirow{2}{*}{$\begin{array}{l}\text { molecular } \\
\text { weight }\end{array}$} & \multicolumn{2}{|c|}{ RESULTS } \\
\hline & & & & peakfronr & $\overrightarrow{K_{\text {a }}}$ \\
\hline $1 s t$ & $\begin{array}{l}\text { blue dextran } 2000 \\
\text { glucose }\end{array}$ & $\begin{array}{l}2 \\
1\end{array}$ & & $\begin{array}{r}40 \\
103\end{array}$ & \\
\hline $2 \mathrm{nd}$ & $\begin{array}{l}\text { cytosol incubated } \\
\text { with } 125 \mathrm{I}-\mathrm{E}_{2}\end{array}$ & & & $\begin{array}{r}45 \\
67 \\
115\end{array}$ & $\begin{array}{c}0.07 \\
0.42 \\
-\end{array}$ \\
\hline $3 \mathrm{rdt}$ & human serum alb. & 1 & 69,000 & 71 & 0.48 \\
\hline 4 th & $\begin{array}{l}\text { cytosol incubated } \\
\text { with } 125 \mathrm{I}-\mathbb{E}_{2} \text { and } \\
\text { DES }\end{array}$ & & & $\begin{array}{r}4.7 \\
117\end{array}$ & 0.10 \\
\hline 5 th & $\begin{array}{l}\text { catalase } \\
\text { bovine albumin } \\
\text { chymatrypsinogen A }\end{array}$ & $\begin{array}{l}3 \\
7 \\
3\end{array}$ & $\begin{array}{r}232,000 \\
67,000 \\
25,000\end{array}$ & $\begin{array}{l}56 \\
73 \\
89\end{array}$ & $\begin{array}{l}0.25 \\
0.51 \\
0.77\end{array}$ \\
\hline $6 \mathrm{th}$ & $\begin{array}{l}\text { ferritin } \\
\text { aldollase } \\
\text { ovalbumin } \\
\text { ribonuclease A }\end{array}$ & $\begin{array}{c}0.5 \\
2 \\
7 \\
10\end{array}$ & $\begin{array}{r}440,000 \\
158,000 \\
43,000 \\
13,700\end{array}$ & $\begin{array}{l}43 \\
64 \\
79 \\
96\end{array}$ & $\begin{array}{l}0.04 \\
0.36 \\
0.61 \\
0.88\end{array}$ \\
\hline 7 the & $\begin{array}{l}\text { blue dextran } 2000 \\
\text { glucose }\end{array}$ & $\begin{array}{l}2 \\
1\end{array}$ & & $\begin{array}{r}41 \\
104\end{array}$ & \\
\hline
\end{tabular}

ESTIMATION OF MOLECULAR WEIGHTS BY GEL FILTRATION ON SEPHADEX G AMD SEPHACRYL ${ }^{\text {B }}$ S-300

For each colum packing a calibration curve was obtalned by plotting the $K_{\mathrm{g}}$ values of reference standard proteins vo the logarithms of their molecular weights. The $K_{\text {aw }}$ values (available partition 
table $8-2$

Get fictution on Sephacm it $8-300$.

\begin{tabular}{|c|c|c|c|c|c|}
\hline \multirow[t]{2}{*}{ Iura } & \multirow[t]{2}{*}{ sample 2 tri } & \multirow{2}{*}{$\begin{array}{l}\text { conc. } \\
\text { mg } / \mathrm{sml} 1\end{array}$} & \multirow{2}{*}{$\begin{array}{l}\text { wecular } \\
\text { weight }\end{array}$} & \multicolumn{2}{|c|}{ RESULTS } \\
\hline & & & & peak fr.nI & $\overline{R_{a v}}$ \\
\hline \multirow[t]{2}{*}{ lat } & blue dextran 2000 & 2 & & 35 & \\
\hline & glucose & 1 & & 89 & \\
\hline \multirow[t]{3}{*}{$2 \mathrm{ad}$} & cytosol incubated & & & 36 & 0.02 \\
\hline & with $125 \mathrm{I}-\mathrm{E}_{2}$ & & & 40 & 0.09 \\
\hline & & & & 56 & 0.39 \\
\hline \multirow[t]{4}{*}{$3 \mathrm{rd}$} & thyroglobulin & 2 & 660,000 & 38 & 0.06 \\
\hline & catalase & 3 & 232,000 & 46 & 0.20 \\
\hline & bowine albumin & 7 & 67,000 & 63 & 0.52 \\
\hline & chymotrypsinogen A & 3 & 25,000 & 74 & 0.72 \\
\hline \multirow[t]{4}{*}{4 th } & ferritin & 0.5 & 440,000 & 41 & 0.11 \\
\hline & aldolase & 2 & 158,000 & $5 \|$ & 0.30 \\
\hline & avalbumin & 7 & 43,000 & 70 & 0.65 \\
\hline & ribonuclease & 10 & 13,700 & 85 & 0.93 \\
\hline \multirow[t]{2}{*}{ Sth } & cycosol incubated & & & 37 & 0.04 \\
\hline & with ${ }^{125} \mathrm{I}-\mathrm{E}_{2}$ & & & 41 & 0.11 \\
\hline \multirow[t]{2}{*}{ 6th } & blue dextran 2000 & 2 & & 35 & \\
\hline & glucose & 1 & & 89 & \\
\hline
\end{tabular}

coefficients) were calculated as follows:

$$
k_{a v}=\frac{v_{e}-v_{o}}{v_{t}-v_{o}}
$$

Where $v_{\text {e }}$ was the elution volume corresponding to peak elution of the standard protein or labelled oestradiol peak, $v_{0}$ was the void volume of the column, determimed with blue dextran 2000 and $W_{t}$ was the total wolume of the packed bed, measured by glucose elution. The 
peak levels of blue dextran 2000 and the calibration proteins were detected by absorbance at $280 \mathrm{~nm}$; the peak of glucose elution was measured spectrophotometrically at 620 nm performing the anthrone reaction on aliquots of the fractions ( 7 ).

\section{RESULLTS}

By gel filtration of cytosol samples previously incubated with $125 \mathrm{I}_{2}$ (tracer), on Sephadex $\mathrm{E}$ ( -150 several fractions appeared to contain protein bound iodine-125. No linear correlation of radioactivity with the protein concentration in the fractions could be observed (figure 8-1). A first broad peak (ftactions 43-46) was foll lowed by an even more extended range of radiosctivity (fractions $63-75)$. Both elution ranges coincided with the elution of protein. A last and wide range of radioactivity was eluted between fractions 90-160 with a distinct peak around fraction nr. 115. Protein eivtion was absent from fraction 118 and onwards. This last elntion of radioactivity must be attributed to free tracer. Incubation of cytosol with tracer and two hundred fold excess DES led to disappearance of radioaccivity in some elution fractions. In the first range radioactivity could still be detected (fractions $44-47$ ) whilst no radioactivity at all was found in the fraction range 63-75. No decrease in elution of radionctivity in fractions $90-160$ was obserwed.

As the only difference between these experiments was the addition of an excess of radip-inert DES to the cytosol-tracer mixture in the second incubation, it could be concluded that in fractions 44 and 47 (peak i figure -1 ) both specific receptor proteins and non-specific binding proteins were eluted. On the comtrary, in the fractions around nx. 67 (peak 2, figure -1 ) only specific receptor protelin was present. A first conclusion can be that the specific binding protein in peak 2 is to be considered as the smaller receptor protein. The specific part of binding protein in peak 1 corresponds 


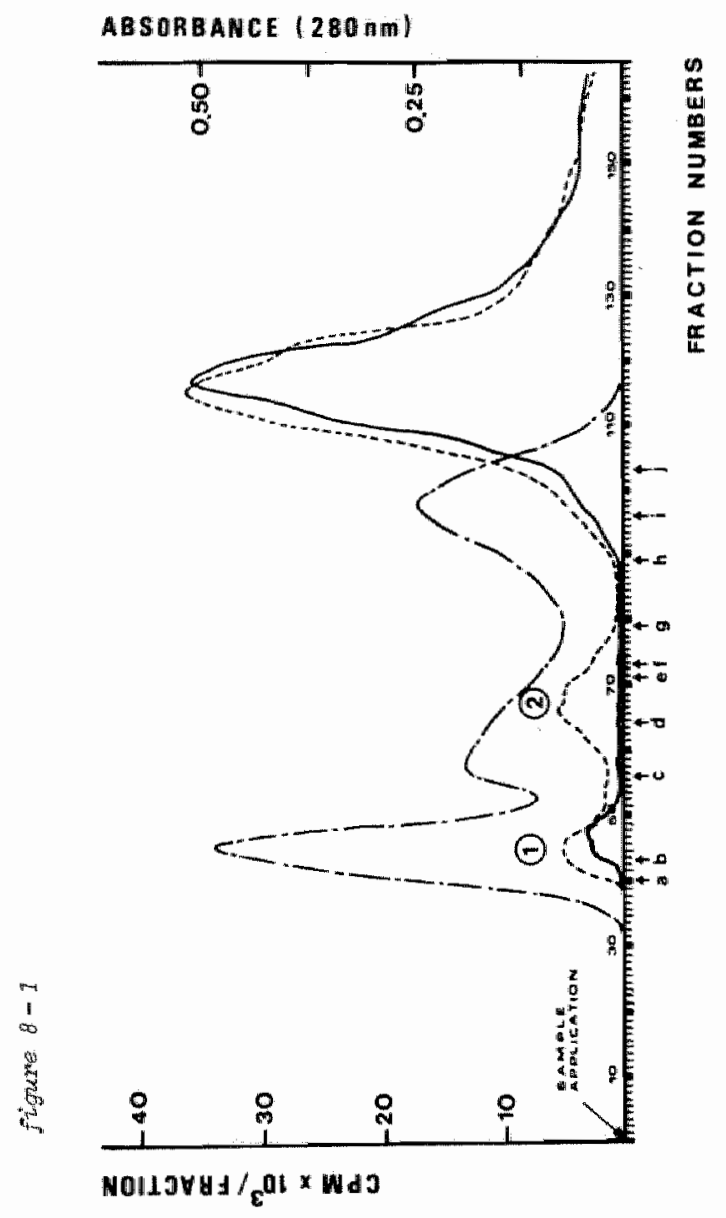


ingee $8-1$

Gelfiltration of cutosols on Sephadex: ${ }^{R-150:}$

- protein absomption (280 $\mathrm{mm})$

-..- radioactivity of frations from cytosol incubated with $125 \mathrm{I}_{2} \mathrm{E}_{2}\left(25.10^{-10} \mathrm{M}\right)$

- radionetivity of frations from cytosol incubated with $125 \mathrm{I}-E_{2}\left(25.10^{-10} \mathrm{M}\right)$ and DES $\left(50.10^{-8} \mathrm{M}\right)$

Peaks 1 and 2 : binding proteins.

Calibration peaks: biue dextran 2000 (a), fermitin (b), adtalase

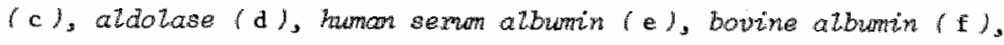
ovalbumin $(\mathrm{g})$, chymotrypsinogen $A(\mathrm{~h})$, ribonuctease $A$ (i) art gluoose $(\mathrm{j})$.

with a larger receptor protein. In both experiments non proteinbound tracer was eluted in the same fraction ramge.

For a number of calibration proteins of known molecular weight the $\mathrm{K}_{\mathrm{av}}$ values for this colurin were callculated (table 8-1). A graphical representation of the calibration of the columa with proteins of known molecular weights against the calculated $K_{a v}$ values was made (figume $8-2)$. From this graph it was possible to estimate roughly the molecular weight of the receptor proteins. These were found to lie around 390,000 (small amount) and around 100,000 (the larger amount).

By piefforming the same experiments with Sephacryl ${ }^{R}$ s-300 different elution patterns were obtained (figure $8-3$ ). This was trute both for protein elution and for elution of radiaactivity. A final separation in the high tholecular weight range was observed where two distinct peaks were eluted (Eractions 36 and 40 ). The first of these appeared to consist largely of specific binding protain whilst the second peak was to larger extent still found after incubation with excess DES. As in the Sephadex gel filtration the low molecular weight receptor activity was to largex extent suppessed in the presence of DES (peak 3, figure $8-3$ ). The high molecular weight 


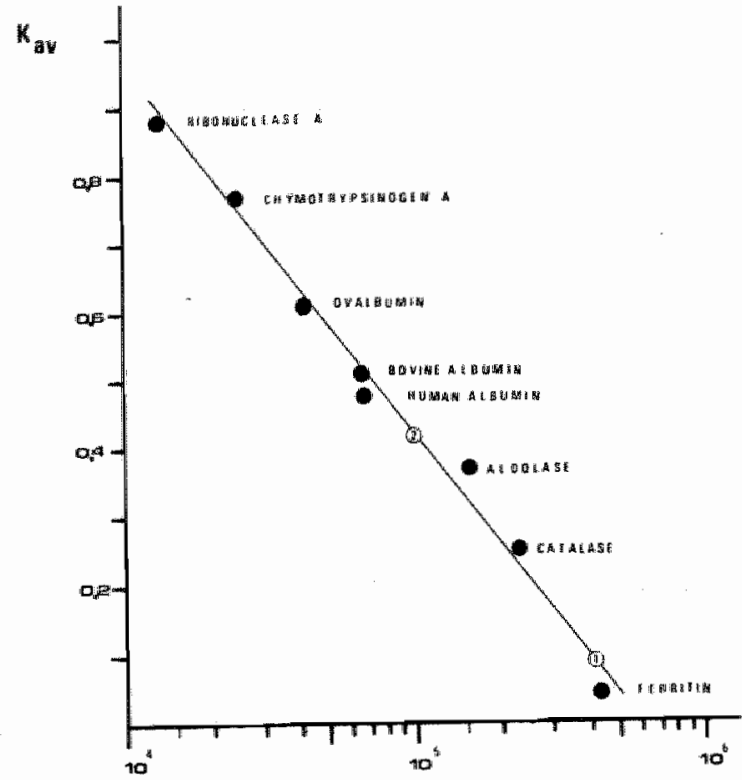

MOLECULAR WEIGHT

rigure $8-2$

Calibration of Sephader G-150 oolwam. Open cimcles 1 and 2 comrespond with binding proteing (see figure -1 and text).

binding protein fraction in the Sephacryl filtration wery clearly cansisted of two different peaks (peaks 1 and 2 , figure $8-5$ ) of which the first wis much suppressed in the presence of DES, indicatiog that this fraction contained predominantly specific receptor protein.

Hurtherwore, a pronounced adsorption chromatographic effect of the Swephacryl towards the free tracer was observed. The latter was "luted in fractions $363-421$ which was far beyond the glucose 


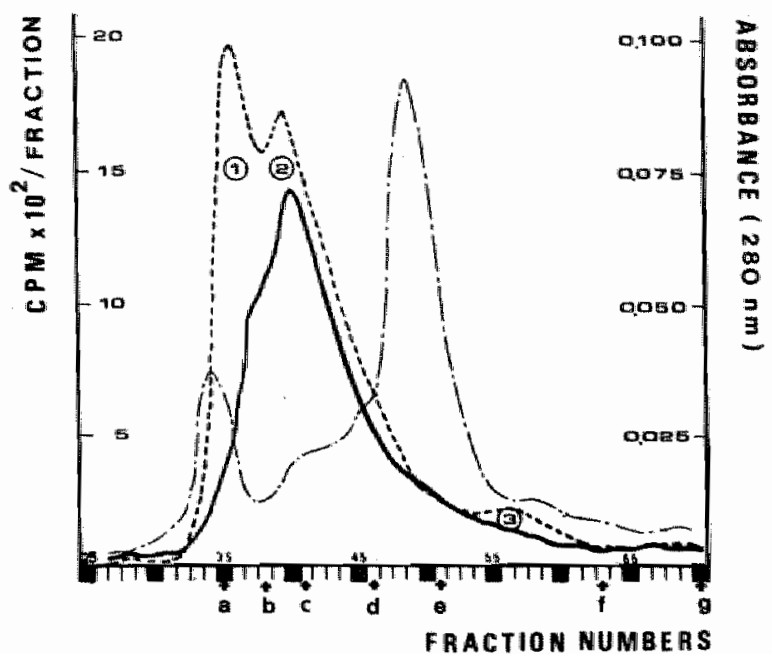

figure $8-3$

Gel filtration of cytosols on sephacm $z^{f} s-300$ :

- - protein abeorption (280 nm) :

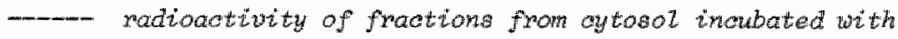
$125 \mathrm{I}-\mathrm{E}_{2}\left(25 \cdot 10^{-10} \mathrm{M}\right)$;

- radioactivity of fractions from outosol incubated with $125 x-E_{2}\left(25.10^{-10} M\right)$ and DES $\left(50.10^{-8} M\right)$.

Peaks 1, 2 and 3: binding proteins.

Gatibration peaks: bitue dextron 2000 (a), thyroglobutine (b), fermine (c), catalase (d), aldolase (e), bowine semam albumin (1) and ovalbumin $(\mathrm{g})$.

fraction (nr 89). The elution volume for the free tracer thus was nearly four times the total volume of the column which mat have been caused by adsorption of the fre steroid to the Sephacryl. 


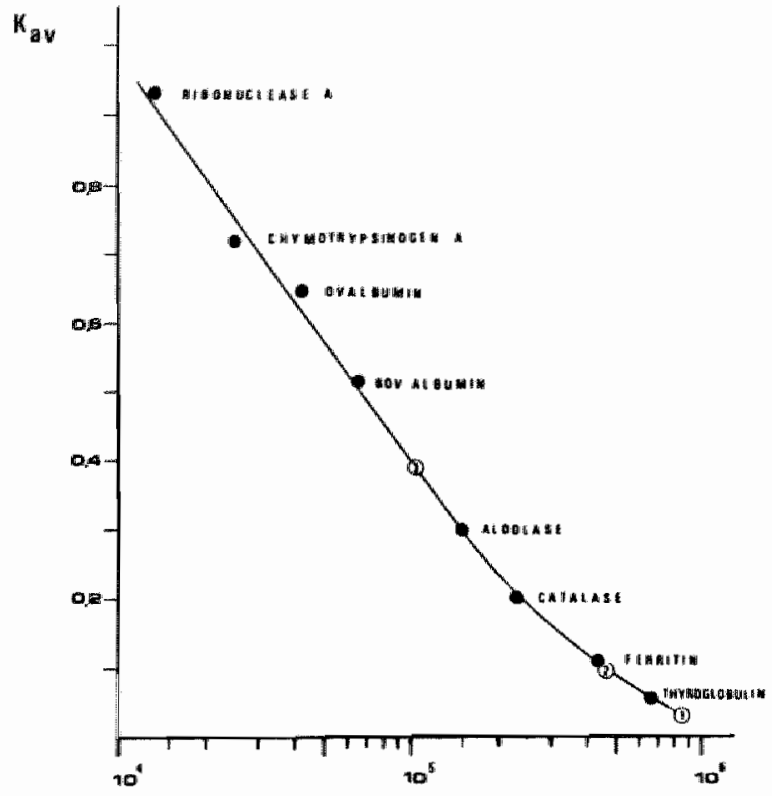

MOLECULAR WEIGHT

figure $8-9$

Calibration of Sephary $Z^{R} S-300$ colum. open ainoles 1,2 and 3 sronegond with binding proteins (oee figure $8-3$ and text).

Calibration of the colum with reference proteing (figure $\theta-4$ ) allowed a rough estimate of the molecular weight of receptor proteins. The two first elution peaks corresponded to molecular weights of 860,000 (specific recetor peak) and 460,000 (non-specific binding protein) and the small peak (fraction 56) contained specific receptor protein of molecular weight around 115,000 . The later vallue was in rough accordance with the value of 100,000 found in the sephadex $G-150$ experiment. The very large protein $(860,000$ molecular 
weight) may have been an aggregate of smaller receptor proteins.

Todine labelled oestradiol was used as a tracer to obtain high sensitivity. Similar experiments were started using ${ }^{3} \mathrm{H}_{-\mathrm{E}_{2}}$ as a tracer. This technique was soon abandoned an account of low sensitivity of measurement of radioactivity. First results were in good agrement with the experiments where the ${ }^{12 S_{1}-\mathbb{E}_{2}}$ tracer was used.

\section{SUCROSE DENSTTY GRADIENT ULTRA CENTRIFUGATION (SDG)}

PREPARATION OF CYTOSQLS FROM HUMAN MAMMARY TUMOUR TISSUE

Cytosols were prepared as described earlier $(5,6)$. No variations in this procedure were allowed during the present study. This method for cytosol preparation was sirilar to the one that has been recomanded by the E.O.R.T.C. (5) and is used in many latworatories.

\section{CHEMECALS}

- $16 a-125$ Iodo $-3,17$ - oestradiol (specific activity $2200 \mathrm{ci} / \mathrm{mmol}$ )

(New England Nuclear).

- Diethylstilbestrol (Sigma).

- Sucrose (Analar).

- Charcoal activated (BDH, decolorizing powder).

- Dextran T-70 (Pharmacia).

- Gelatin isis (Merek).

- All other chemicals used were commercial products of analytical grade.

\section{REAGENTS}

- Tris-HCl buffer $10 \mathrm{mM}$, pll 7.5 at $25^{\circ} \mathrm{C}$, containing 1 me EDA. 
$3 \mathrm{mM} \mathrm{Nan}$; and $0.5 \mathrm{~m}$ dithiatheltol (TED buffer).

- Dextran coated charcoal (DCC) suspension, prepared by adding $0.5 \mathrm{~g}$ of charcoal to 100 mil of TED baffer containing $0.5 \mathrm{~g}$ of dextran $\mathrm{T}-70$ and $0.2 \mathrm{~g}$ of gelatin.

\section{SAMPLES}

Cytosol samples were prepared and incubated as described for gel filtration (vide supra). In some cases the free oestradiol and DES were removed by stirring a wollume of the incubated sample with a pellet obtained by centrifugation of an equal volume af DCC suspension. The mixtures were agitated for 20 minutes at $2^{\circ} \mathrm{C}$ and centrifuged at $2000 \mathrm{~g}$. Aliquots of the supernatant were layered on the sucrose gradient.

\section{SDG ERUIPMENT}

SDG equipment consisted of:

- Beckman ultracentrifuge type L2-65B with swing out rotor type SW $60 \mathrm{TH}$ was used with poly allomer tubes $5 \mathrm{ml}$. The tubes were punctured using a fraction recowery system (Beckman).

- Modified multi-channel gradient former (Cenco).

- Spectrachron-F photometric detector (Gilson) cannected with a recorder (BDC, input .100 mV. Kipp \& Zonen).

- Fraction collector MTDC (Gilson),

- Peristaltic punap Minipuls II (Gilson).

- Yacounter $\mathrm{NE}_{\mathrm{H}} 1621$ (Wuclear Enterprise).

\section{PROCEDURE}

- Linear sucrose concentration gradients of 5-25z or 5-30z sucrose in TED buffer were prepared at $2^{\circ} \mathrm{C}$ in polly allomer 
ultracentrifugation tubes of $4.4 \mathrm{ml}$ volume.

- Samples (volume $100-200$ w) were cautionsly layered on top of the sucrose gradients. Bovine serut albunin was used as a marker. protein $(4.6 \mathrm{~S})$.

- The tubes were placed in cold rotor buckets $(20 \mathrm{C})$ and centrifuged for 17 hours at $300,000 \mathrm{~g}$.

- The bottoms of the tubes were punctured and a solution of sucrose ( $45 \%$ containing $1 \%$ blue dextxan 2000) was puped into the bottom of the gradient tubes displacing the protein containg gradient solution.

- The peak levels of proteins and blue dextran 2000 were continously monitored at $280 \mathrm{~nm}$.

- Fractions were collected and their ratioactivity mearured.

\section{$\underline{\text { RESULTS }}$}

A first series af experiments was performed where free homone: were not removed with a DCC pellet. Three tracer binding peaks were Found, viz. in fractions 8 (peak 1), 15 (peak 2) and 32 (peak 3) (figure 8-5). After suppression of specific binditag with DES peak disappeared almost completely indicating the presence of $4 \mathrm{~S}$ receptor protein in the tumour cytosol. Peak 2 disappeared to some extent leaving a certain degree of unspecific binding as was also reported elsewhere (8). Peak 3 appeared to consist of non-specific binding protein. At the botcom of the tubes a small amount of nonspecifically bound tracer was always detected (fraction 61). Tracer in this fraction must have been bound either to very high molecular weight or to strongly aggregated proteins.

In another sexies of experinents the influence was studied of removing the free homones with a DCC pellet after incubation of the cytosal. with hormanes. Simultaneoug runs of amples either without or with DCC treatment were analysed (figure $8-6)$. It was observed that treatment with coated charcoal before $\mathrm{SDC}$ analysis removed not 


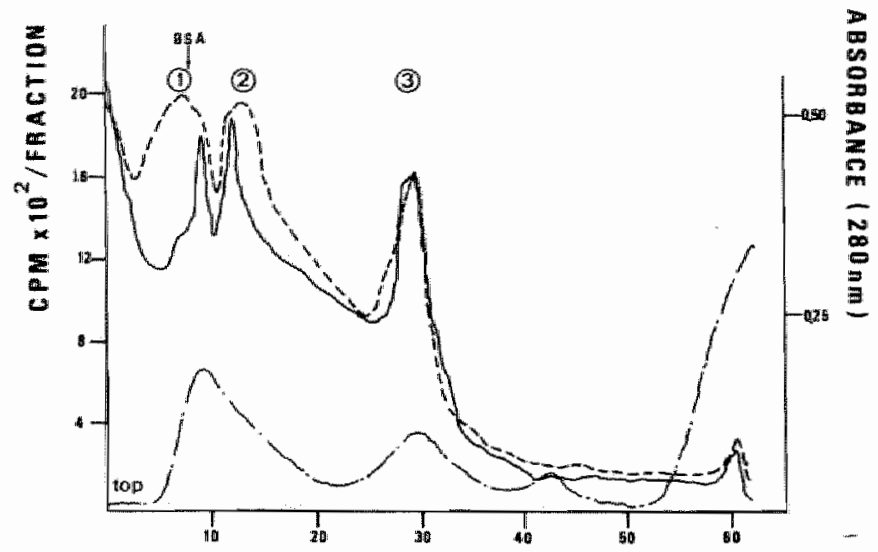

FRACTION NUMBERS

figure $8-5$

Sucrose density gradient aentrifugation of human mamamy twour $(E R+)$ cytosol:

- protein absorption (280 non);

- madioactivity of fractions from cytosol incubated with 125 $\left(25.10^{-10} \mathrm{~W}\right)$ (peak 1, 2 and 3$)$;

- radiaactivity of fractions from cytosol incubated with ${ }^{125} \mathrm{I}-E_{2}\left(25.10^{-10} \mathrm{~W}\right)$ and DES $\left(50.10^{-8} \mathrm{M}\right)$.

Sucrase gradient: $5-25 \%$ sucrose in TED buffer.

Sample size: 0.2 mi.

Centrifugation: 17 howng, $300,000 \mathrm{a}, 2^{\circ} \mathrm{C}$.

Faction volume: 75 in 65 drops).

only free tracer but also considerable amount of protein bound tracer. The residual total radioactivity in the protein containing fractions was greatly diminished and the free tracer radiaactivity (top of the tube) disappeared. Furthermore, it could be observed that 
figure $8-6 a$

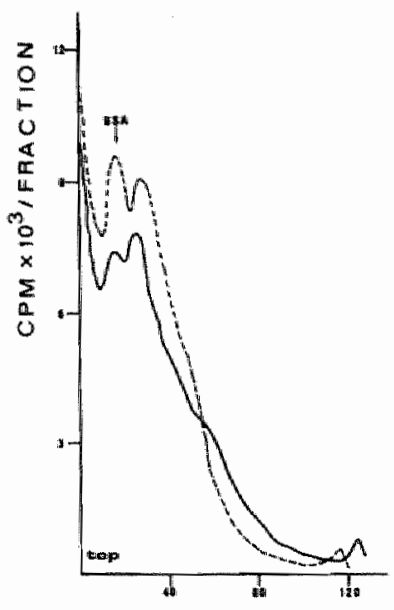

FFACITION NUMAERS figume $8-6 b$

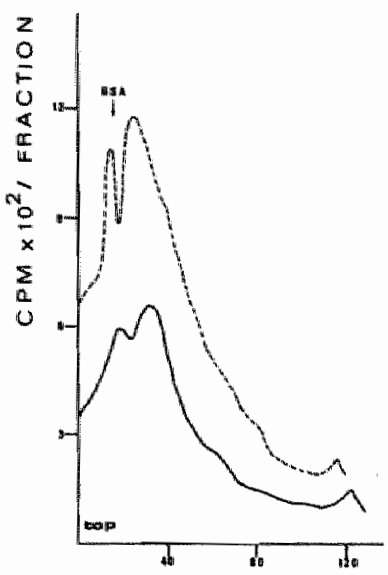

FRACTION NUMBERS

figure $8-6$

SOG anatysins of hwom mamary twnour (ER+) cytosaz:

a. without treatipent of inewate with dextron coated oharoal

b. With treatment of inoubate with dextran coated charcoal.

-- Radiactivity after incubation whth ${ }^{125} \mathrm{I}-\mathrm{E}_{2}\left(25.10^{-10} \mathrm{~W}\right)$.

- Radioactivity after incubation with $125 I-E_{2}\left(25.10^{-10} \mathrm{M}\right)$ and DES $\left(50.70^{-8} \mathrm{M}\right)$.

Siworose gradiant: $5-30 \%$ anarose in meb-buffer.

Sample gize: $0.15 \mathrm{ml}$.

Centrifugation: 17 hours, $300,000 \mathrm{~g}, 20 \mathrm{C}$.

Fration watume: 30 wl ( 3 aropa). 
figure $8-7 a$

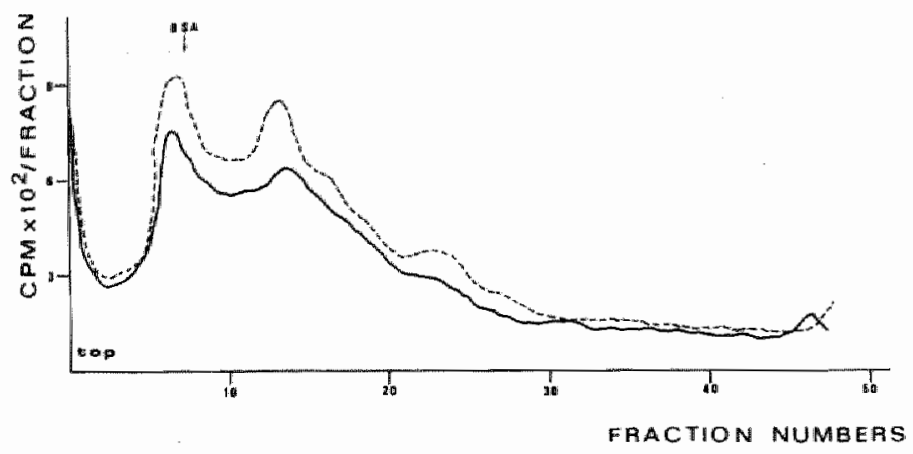

figure $8-7$

SDG anctyais of hutan mamary twmowe (ER+) cytosot:

a. ultracentrifugation in swerose gradient in TED buffer

b. Wltracentrifugation in awerose gradient in Two buffer contating

$0.1 \mathrm{MKC}$.

--1- Radionetivity after incubation with $125 \mathrm{I}-E_{2}(5.10-10 \mathrm{M})$.

Radioaotivity after incubation with $125 \mathrm{I}-\mathrm{E}_{2}\left(5,10^{-10} \mathrm{M}\right)$ and DES $\left(10.10^{-B} \mathrm{M}\right)$

Sucrose gradient: $5-30 \%$ sucrose.

Sumple size: $0.2 \mathrm{mi}$.

Centrialugation: 20 houra, 300,000 g, $2^{\circ} \mathrm{C}$.

Fraction voliume: 75 wi (s arops).

relatively less radiagtivity in the $4 \mathrm{~s}$ region (peak 1 in figure $8-6 a$ and in figure $8-6 b$ ) remained than in the thigher molecular weight fraction (peak 2 in fighre $8-b a$ and in figure $8-6 b$ ). This is posibly the result of stronger adsorption of the smaller receptor proteins to DCC (9). Here good agreement was found with earlier data 
figure $8-7 b$

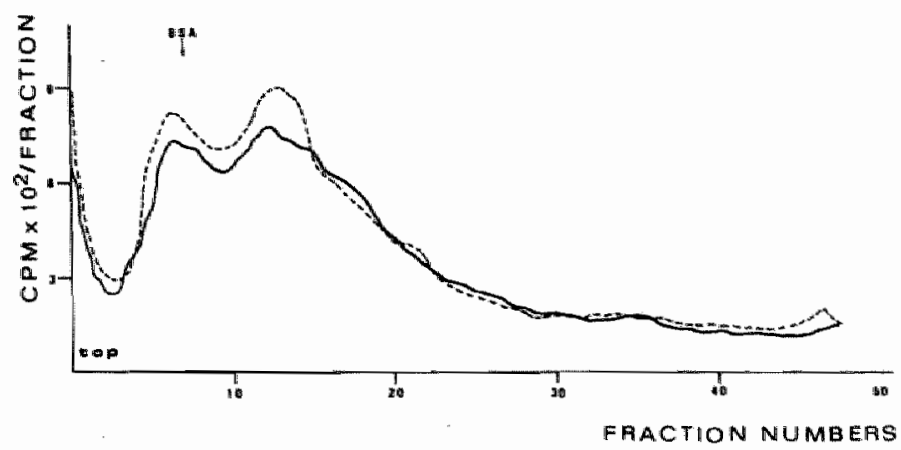

on the adsorption of receptor-tracer complex by DCG $(6$, and ofluptura 2 of this thesis). Moreover, it has been reported (10) that in different tumour cytosols changing patterns of receptor proteins can be found, ranging from only pure $8 \mathrm{~s}$ proteins to predominantly $4 \mathrm{~S}$ proteins and combinations in all possible proportions.

In a thind series of experiments the influence of adding KG1 to the cytosol was investigated. It has been reported (11) that dissociation of $8 \mathrm{~S}$ receptor proteins into $4 \mathrm{~s}$ proteins could be observed in the presence of $\mathrm{KCl}(0.4 \mathrm{M})$. In order to study this salt effect RCl was added in a final concentration of $0.1 \mathrm{M}$ in the sucrose gradient solution. From figure $8-7$ it can be learned that no obvious shift from larger to smaller receptor proteins occurred during ultracentrifugation. However, a cartain decrease of specifie binding activity was observed. Whether this wa due to denaturation aft receptor protein during the procedure could not be established. 
Cytosols whe prepared as described earlier $(5,6)$. wo variations in this procedure were allowed during the present study. This method for cytosol preparation sistar to the one that has been recomanded by the B...R.T.C. ( 5 ) and is used in many laboratories.

\section{CHEMICALS}

- $16 a-125$ Iado-3,17b-oestradioll (specific activity: $\approx 200 \mathrm{Ci} /$ mol) (New England Nuclear) (125 $\left.\mathrm{I}-\mathrm{E}_{2}\right)$.

- Diethylstibesterol (Sigma).

- All other chemicals used were comercial products of analytical grade.

\section{REAGENTS}

- Tris-HCl buffer $10 \mathrm{HM}$, pH 7.5 at $25^{\circ} \mathrm{C}$, containing 1 mM EDTA, $3 \mathrm{mM} \mathrm{NaN}_{3}$ and $0.5 \mathrm{~mW}$ dithiathreitol (TED buffer).

- Electrophoresis buffer: tris $90 \mathrm{mM}$, borate $80 \mathrm{mM}$, pH 8.2 at $0^{\circ} \mathrm{C}$, containing 3 inM $\mathrm{Na}_{2} \mathrm{EDTA}$.

- Staining solution: 0.5\% Coonassie Brilliant Blue dissolved in 5\% methanol in $21 \%$ aceetic actd solution.

- Destaining solution: $0.5 \%$ methanol in $21 \%$ acetic ac da solution.

- Sirface autoradiography enhancer EN ${ }^{3}$ HANCETM spray (NEN).

\section{SAMPLES}

Manmary tumours cytosols were prepared and incubated as described 
for SDG analysis. The sanple density was increased by dissolwing sucrose to obtain $25 \%$ sucrose concentration. Unbound tracer was in some cases removed by DCC pellets. The applied sample volumes were 10 to $50 \mathrm{HI}$. High and low molecular weight calibration proteins (Pharmacia) were dissolved in TED buffer (100 pl/vial); 5 H1 samples were used.

\section{EQUI PMENT}

- Polyacrylamide gradient gel slabs, concave gradient of $4 \%$ to $30 \%$ (separation range for globular proteins 50,000-2,000,000 molecular weight) (Pharmacia PAA $4 / 30$ ).

- Gel electrophoresis apparatus: Uniscil/ Gradipore Electrophoresis unit (Tempus) for 4 slabs.

- Electrophoresis power supply LRB 2103 (with constant vollage).

- Gel silicer ( $3 \mathrm{~mm}$ ).

- Film: Definix medical (Kodak).

- $\gamma$-Counter NE 1612 (Nucleax Enterprise).

\section{ELECTROPHORESIS PROCEDURE}

- The whole procedure was performed at $1^{\circ} \mathrm{C}$.

- After pre-equilibration of the gel slabs (30 min, 100 V) with circulating buffer, the samples (cytosols and callibration proteins) were applied and pre-electrophoresis was applied for 20 min at $80 \mathrm{v}$ (without circulating buffex) until the proteins moved into the gel.

- The circulation of the buffer was then re-setablighed and the electrophores is was performed for 16 hours at $130 \mathrm{~V}$ (conitant voltage).

- Mfter electrophoresis the staining procedure was pexformed with the staining solution (20 min) and excess of dye was removed by diffusion for 24 hours in the destaining solution.

- Samples were routinely applied to two gel slabs; after 
electophoresig the firgt was used for the staining procedure and calibration of the molecular weight curve; the second was used for determination of ralloactivity of the silices.

\section{MOLECULAR WEIGHT ESTIMATION}

The molecular whe figt of the radioactivity binding proteins were etimated by comparison of their electrophoretic mobility with those of che calibxation proteins. A calibration curve was made by plotting the $\mathbb{R}_{f}$ (relative mobility) of the calibration proteins ps. the logarithm of their molecular weight. By means of the determined $\mathbb{B}_{1}$ valueg of the radionctivity binding proteins the molecular weights were estitnated.

\section{RESULTS}

Polyacrylamide gradient gel electrophoresis was performed on cytosol sanples after incubation with labelled oestradial (125 $\left.\mathbb{I}-\mathbb{E}_{2}\right)$, either with or without excess diethylistilboestrol (DES). After electrophores is the gel slabs were cut into 3 mick thices ("fraction:") and the radiolactivity was measured. From stained duplicates the position of calibration proteins on the electropherograms could be indicaced.

In a first series of experiments several peaks of radioactivity were observed (figme $8-8$ ). Afirst peak of very high activity at the starting point of the electropherogram indicated the spot whete free tracer was found. A "shoulder" peak next to the first one conld not be suppressed by excess DES. It must be assuned that very high molecular weight proteins / protein aggregates non-specifically bound sone tracer. However, two other peaks of radioactivity (peak 1 and peak 2 in fighe $8-8$ ) were to a major extent suppressed when DES was added during the incubation. It must be concluded that specific 


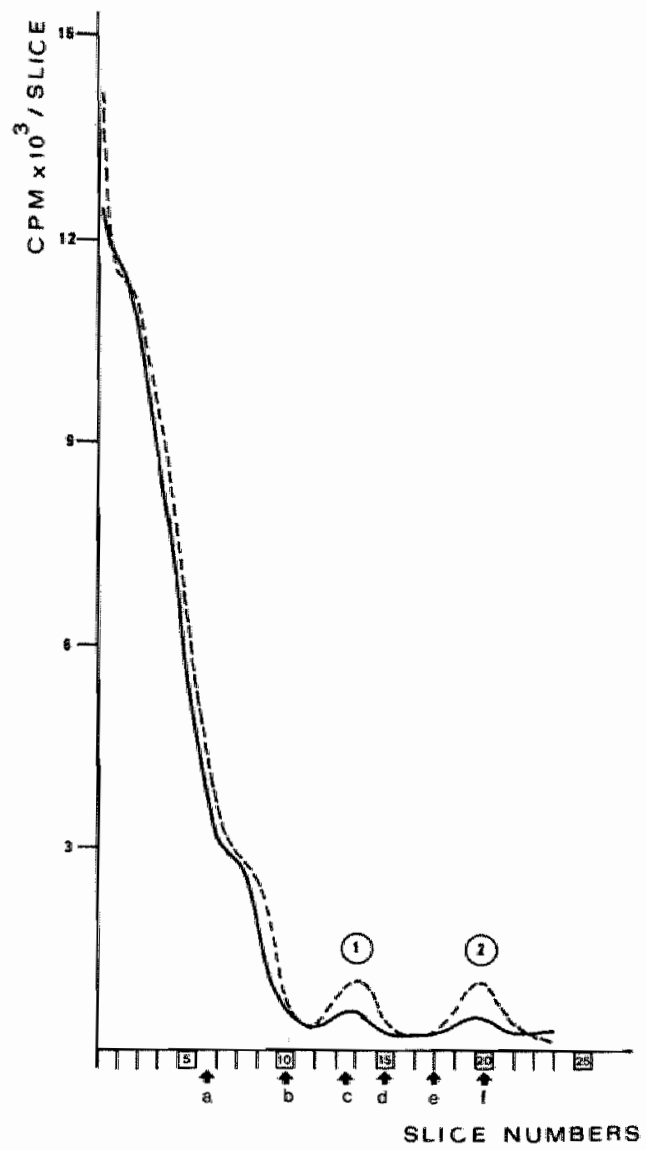

Pigure 8-8

Polyadry tamde gradient get aleatrophoresis of obtowol probeine.

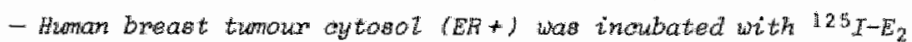
without (broken line) or with (solid line) aditition of DES.

- Peaks i and 2 contain apeoifio reaptor proteino.

- Calibration peaks: thyroglobuzin (a), fermitin (b), catalage (c), Lactate dehydrogenase (d), phoaphorylase-b (e), bonine aerum albumin (ff). 


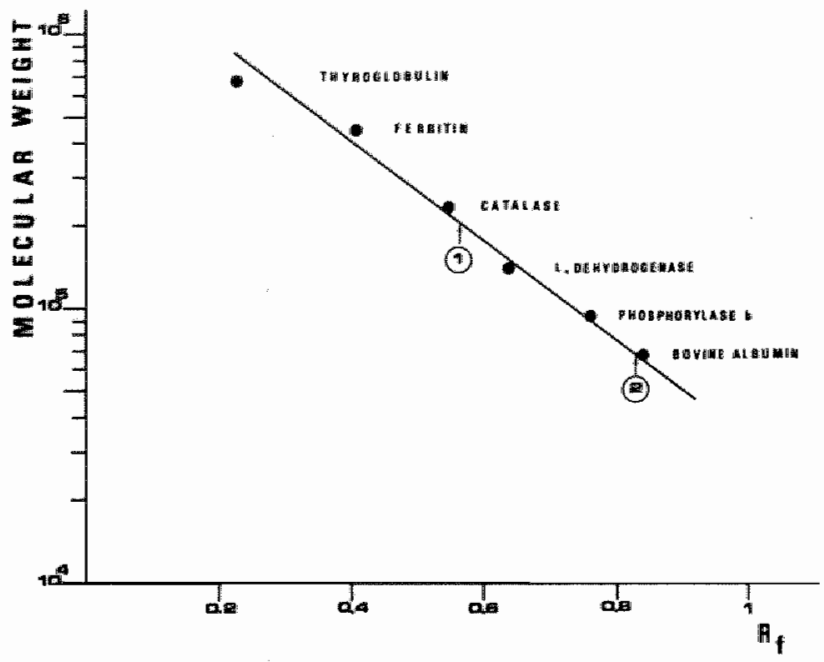

figure $8-9$

Calibration of polyacrylamide gradient gel corresponding to figure $8-8$.

receptor proteins were found here. From the protein calibration curve (figure 8-9) molecular weights in the ranges of 205,000 for peak 1 and 66,000 for peak 2 could be calculated.

In a second series of experinents the excess tracer was removed with a DCG pellet after incubation. In the electropherogram ffigure (3) - 10) no free tracer was abserved. Again non-specific high molecular weight binding proteins were found. As in the first experiments two fractions (peaks 1 and 2 in figure $8-10$ ) contained specific binding proteins in inilar molecular weight ranges, i.e. 190,000 and 72,000 (figure $8-11)$. It could be remarked that residual radioactivity in the protein fractions was considerably lower than without $D C C$ treatment. Autoradiography of the electropherogram was attempted. No 


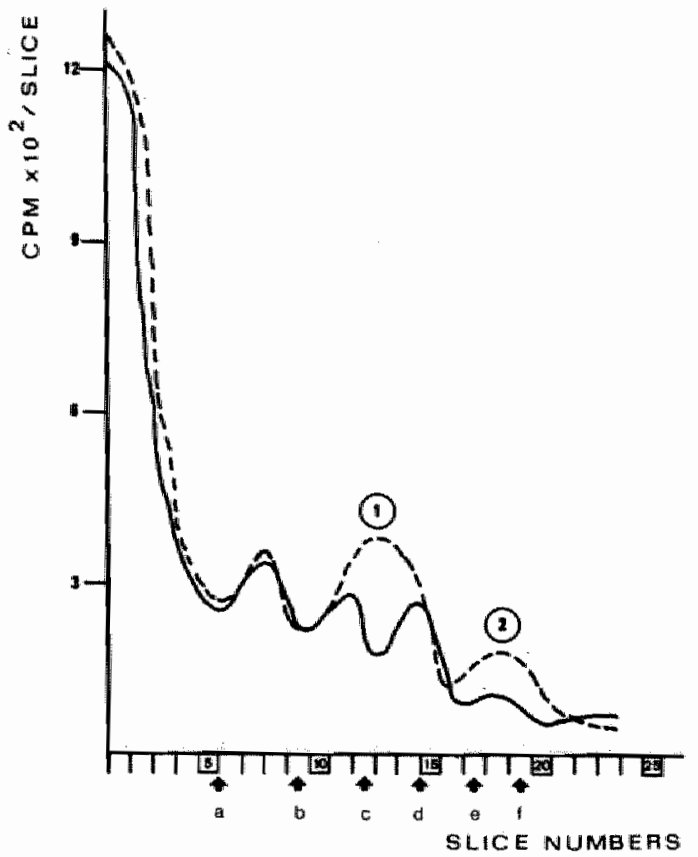

figure $8-10$

Potyacry lamide gel elootrophoresig of ay tosot protein.

- Euman breast tumour aytoeal (ER+) was incubated with 125 I-E (s. $10^{-9} M$ ) without (broken line) or with (aotid tine) addition of DES $110^{-5}$ H. The incubation mixtwe was treated with dewtron coated aharooal before lectrophoresis.

- Peaks 1 and 2 contain spectifio moptor protetin.

- Calibration peaks: thyroglobulth (a), ferrittin (b), catalate ( $\mathrm{c}$ ), Zactate dehydrogenase ( $\mathrm{e}$ ), phophorytase-b (fi) and bovine iserum albumin $(\mathrm{g})$. 


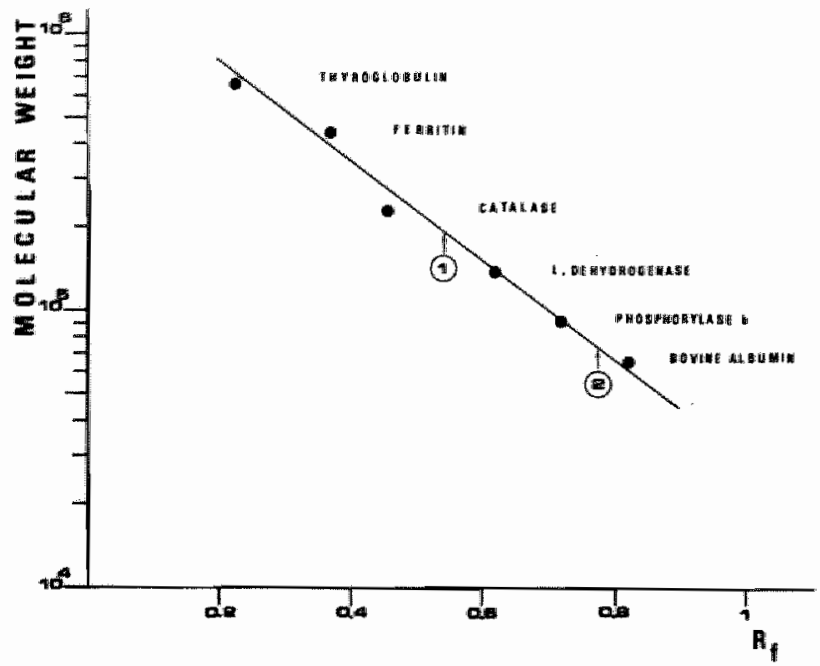

figure $8-11$

Caltbration of polyadrilamide gradient gel corresponding to figure $8-10$.

valuable results could be obtained. Short contact showed no detectable stains on the film whilst longer exposition (1 month) produced diffuse spots from which no conclusion could be made.

\section{OISCUSSION}

In the present study several oestradiol binding proteins were found in breast cancer tissue cytosols. Obvilously some of these proteins had a rather linited binding capacity and could be saturated with an excess of "cold" hormone (DES) whereupion no further uptake of labelled oestradiol occurred. These proteins must be considered as specific oestrogen receptors. The continuing uptake of labelled 
tracer even in the presence of considerable excess of diethylstilboestrol must be attributed to the large binding capacity of unspecific proteins.

It could also be concluded that gel filtration is a valuable and rather simple (and inexpensive) procedure to detect specitic oestrogen receptor proteins. Especially the use of Sephacry ${ }^{R} \mathrm{~s}-300$ could be recomended because separation time was much shorter then with the more classical Sephadex collums. Attention must be paid, however, to the retention of free tracer on the Sephacry ${ }^{R}$ colum, which must be eluted completely before a following run could be started, in order to avoid contamination. Moreover, Sephacryi ${ }^{P}$ s-300 is sold as a pre-swollen preparation so that equilibration of colums packed with it, is rapidly pertormed.

The existence of different molecular forms of oestrogen receptor proteins has of ten been reported $(12,13,14,15)$. This is somet indes attributed to aggregation of receptor as such or with other proteins due to the influence of the mediun (temperature, pH and ionic strength), although the suggestion has also been made that larger receptor molecules might dissociate during extraction and isolation. Specific binding proteins having sedimentation coefficients of $4 \mathrm{~S}$ and $8 \mathrm{~S}$ are often found, with corresponding molecular weights. In gel filtration higher values were reported then in sucrose density gradient analysis $(16,17)$. Our results were in good agreement with these data from the literature.

In gel filtration a considerable amount of lower mollecular weight receptor protein with a roughly estimated molecular weight of about $100,000-115,000$ (figume $8-1$ and figure $\theta-2$ ) was invariably found. This corresponds quite well with the 4 is receptor protein found in sucrose density gradient analysig (figure $8-5)$. That the nolecular mass for this receptor was higher in gel filtration than in sib analysis may well be explained by the hypothesis that probably in the process of gel filtration aggregation of proteins occurred as has 1 so been reported by others $(13,14)$. In the determination of molecular weight of receptor proteins by gel filtration a nuber of 
different values have been reported in conection with several processes to which the native cytosols were subjected. Amongst these fractionation by amonium sulphate precipitation, affinity chromatography and isoelectric focusising must be mentioned. Values ranging from about 70,000 (close to albumin) to about 440,000 (close to ferritin) hawe been reported (15).

larger volecular weight receptor proteins were also inwariably found in our experiments which might correspond to the 8 st receptors often reported in the literature. It may be assumed that the higher values found in gel filtracion (figure $8-3$, peaks 2 and 1 ) correspond to $8 \mathrm{~S}$ receptor procin and aggregations of it. Molecular weights even as large as 860,000 were found (figure $8-4$ ). Similar phenomena were observed in SDG analysis (figure $8-5$ ) and this has also been reported elsewhere $(10)$. In order to prevent aggregation of nonspecific to specific banding proteins or aggregation of receptor proteins as such treatment of the cytosiol with small amounts of proteolytic enzymes stuch as trypsin $(2 \theta)$ or addition of ca ${ }^{++}$-ions or other chaotropic salts $(13,19)$ or heparin (17) have been suggested. In our opinion, however, this could easily provoke artefacts. Otherwise it has been suggested that the prevalence of $4 \mathrm{~S}$ receptor protein might be an artefact due to endogenows proteolytic activity in the cytosol. ( 20 ). Whatever it is the smaller receptor proteins were always found in our investigation and the larger and very large molecular weight forms were encounted to a variable extent.

In the polyacrylanide gradient gel electrophoresis two distinct specific receptor protein fractions were found in the molecular weight ranges of 230,000 and 70,000 . A highiy aggregated or high molecular weight binding protein was also found which was no surprise on accout of the denturing properties of the gel medium employed (21). In general, the electrophoresis experiments confirned the results of the gel filtration and swcrose density gradient studies, including the binding of protein-tracer complexes by dextran coated charcoal.

As a tracer in most experiments iodinated oestradiol was used. 
Although steric effects right change the behaviour of this compound compared to oestradiol, no difference was obserwed between the results of this tracer and tritiated oestradiol (2\%). As iadinell 5 i.s a $\gamma$-emitter the measurement of radioactivity with this isotope is easier then with tritium, a B-emitter. This makes such an investigation also possible for laboratories where no liquid scintillation equipment is avallable. Moreover, the sensitivity of $y$-measurement is generally grester which improves the detection limit of the tracer-receptor complex.

\section{REFERENCES}

1. Erdos, T. and Fies, I. (1979) The endometrid nuclear estratiol receptor of the pregmant cow has a malecul ar weight of 53,000 in $6 \mathrm{M}$ guanidine-HC1. Moler. Ce11. Fndocrinol. 13, 203-209

2. Ginsburg, M., Greenstein, B.D., Mc Lusky, N.J., Morris, I.D. and Thomas, P.J. (1974) An improved method for the study of high affinity steraid binding. Steroids $23,773-792$

3. Wagner, R.K. (1978) Extracellular and intracellular steroid binding proteins. Acta Endacrinol. (Kbh) suppl. $218,20-22$

4. Jensen, E.V. (1975) Estrogen receptors in hormone-dependent breast cancer. Cancer Res. $35,3362-3364$

5. E.O.R.T.C. Breast Cancer Cooperative Group (1973) Standards for the assessment of estrogen receptors in human breast cancer. Europ. J. Cancex 9, 379-381

6. Ralet, Ph.G.F.A.H. and Brombacher, P.J. (198H) The use of coated charcoal in the determination of oestrogen receptor activity. Eur. J. Nucl. Med. (in pressy

7. Scott, T.A. and Melvin, E.H. (1953) Deteraingtion of dextian with anthrome. Anal. Chem. 25, 1656-1661

8. MC Guire, W. L. Chamness, G.C., Costlow, M.2. and Shepherd, R.E. (1974) Subcellular biochemizery of estrogen in breast cancer.

Pag. 75-110 in: Mc Kerns, K.W. (Ed.) Hormones and cancer (Academic Press, New York) 
9. Chester, Z., Feherty, F., Kellie, 位.E. and Ralphs, DuN.L. (1975) Estrogen receptor in primary breas tumours in relation to the stage and progression of the disease. Pag. 157-174 in: Mc Guire, W.L., Carbone, P.P. and Vollmex, E.P. (Eds.) Estrogen receptors in human breast cancer (Raven Press, New York)

10. Tobin, E.H., Bloom, W.D., Pertschuk, L.P., Berman, P.J. and Degenshein, G.A. (1977) Estrogen and progesterone receptor protelnu in human mammaxy carcinoma. Pag. 181-197 in: Agarwal, M.K. (Ed.) Multiple molecular forms of steroid hormone receptors (Elsevier, Arosterdam)

11. Schmeider, S.L. and Dao, T.L. (1977) Effect of Ca ${ }^{\#}$ and salt on forms of estradiol cytoplasmic receptor in human neoplastic breast tissue. Cancer Research $37,382-387$

12. Fazekas, A.C. (1979) Analysis of estrogen receptors in human breast cancet by molecular filtration on Sephacry ${ }^{R} \mathrm{~S}-200$ columns. J. Steroid Biochem. 10,711-713

13. Auricchio, F., Rotondi, A., Sampaolo, P. and Schiavone, E. (1978) Oestrogen receptor of mamary gland. Biochem. J. $169,481-488$

14. Auricchio, F., Rotondi, A., Sampaolo, P. and Schiavone, E. (1978) Cytosol estrogen receptor of lactating mamary gland effect of heparin on the aggregation of the receptor and interaction of the receptor with heparin sepharosie. Biochem. J. $171,137-142$

15. A1-Nuaini, N., Davies, P. and Griffiths, K. (1979) Purification the cytoplasmic estrogen receptor from mammary tumours induced in rats with DMBA. J. Endocrin. 80, 119-130

16. Sawlow, E.D., Mitcliff, J.L., Hilf, R. and Hall, T.C. (1974) Correlations between certain biochenical properties of breast cancer and response to therapy. Cancer 33, 303-309

17. Molinary, A.M., Medici, N., Monchamont, B. and Puca, G.A. (1977) Estradial receptor of calf uterus: interaction with heparinagarose and purification. Proc. Natl. Acad. Sci. U.S.A.74, $4886-4890$

18. Truong, H. and Beaulieu, E. E. (1974) Parameters influencing the purification of calf uteris estrogen receptor by affinty chromatography. F.E. B.S.-lettersi $46,321-325$ 
19. Puca, G.A., Sica* V., Nola, E. and Mresciani, F. (1979) Purification and properties of native estradiol receptor. I. Ster. Biachen. 11, 301-305.

20. Notides, A.C., Hamilton, D.E., Rudolph, J.H. (1973) The action of human uterine protease and the estrogen receptor. Endocrinology $93,210-216$

21. Weber, $\mathrm{K}$. and osborn, M. (1969) The reliability of molecular weight deterninations by dodecyl sulphate ployacrylamide gel electrophoresis. J. Biol. Chem. 244, $406-4412$

2. Hochberg, R.B. and Rosner, W. (1980) Interaction of $16-a-(125 I)-$ iodo-estradiol with estrogen and other steroid binding proteins. Proc. Nac1. Acad. Sei. U.S.A. $77,328-332$ 

chapter 9

GENERAL SURVEY ANO CONCLUSIONS

From the foregoing chapters it is clear that the determination of oestrogen receptor proteins is of great importance for the clinical treatment of patients with breast cancer. A nuber of aspectis are to be considered amongst which are the presence or absence of specific oestrogen binding proteins in the tumour tissue and the presence or absence of progesterone receptor tissue. The correct techniques for these determinations of course are of extreme importance because so much is contributed by the results of these andyses to the possibilities of treatment and prognasis for the patients. For this reason the foregaing study was performed and several aspects are to be considered.

It can now be stated chat the use of caated charcoal in the determination of oestrogen receptor concentration is stili the method of choice for several reasons. In the first place, it is a conventent: and easily applied technique, which from this point of wiew can only be compared to the protamine sulphate precipitation method. The latter, however, presents still a number of difficulties. This is also true for the dextran coated charcoal procedure and several aspects of this technique have been extensively studied. It can be concluded that strict standardisation of the technical procedure is obligatory in order to obtain reliable and reproducible results. This otandardisation is not only required for the receptor determination itself, but also for the preparation of the reagents used in the estimation, e.g. the coating of charcoal by dextran.

Another important featuxe of the determination of oestrogen. proteins is the determination of unspecific protein in mamary 
tumour cytosols. Hways, a certain amomt of non-cytoplasic protein is present of wich the greater part consists of plasma protein. A reasomable estimate of the concentration of the latter can be made by specific immunochemical determination of the human aerum albumin content in the cytosols. In our opinion it is strictiy necessary to make a correction for these non-tumour proteins and to reassess the criteria for bestrogen receptor positivity ( $E R+$ ) or aestrogen receptor negativity $(\mathbb{E}-)$.

Furthermore, the influence of buffer composition, temperature and pH in the cytosols and in the buffers which are used in the deternination, seenus to be important. Although the oestrogen binding activity of the receptor proteins within a certain pli range seems to be uninfluenced, it is also true that at elevated ph values too much mon-receptor protein is extracted and on the other hand, at too low pH values the receptor protein activity is greatly reduced.

Charaterisation of the receptor proteins confirmed some studies published ellsewhere. It appeared not to be possible to isolate and fully characterise the specific receptor prateins. Especially the question whether the so-called $4 \mathrm{~S}$ proteins must be considered to be an artefact, produced from $8 \mathrm{~S}$ proteins by proteolytic activity within the cytosiols, could not be answered unambiguously.

It must be concluded that the clinically very important deternination of aestrogen receptor proteins has to be standardised as $f a r$ as the technique of deternination is concerned. It must be assumed that this standardisation should also be applied to the excision of tumour tissue and the treatment of the latcer before it is presented for analysig, e.s. cooling after exision, short time between excision and transport to the laboratory, etc. The dextran coated charcoal method as recommended by the E.O.R.T.C. can quite well be used, al though further study is necessary to improve the procedure or to replace it by more specific methods. 


\section{SUMMAMA}

A general introduction and survey of the available literature on the clinical importance of the determination of oestrogen receptors is given in ohater 1. Techniques for the detemination of these receptors are also shortly reviewed. The purpose of the present study w』s concluded from these introdictory considerations: the investigation of several aspects of the determination of oestrogen receptor proteins in mamary tumour tissue cytosols.

In chapter : the use of coated charcoal in the determination of: oestrogen receptor activity is extensively studied. It appeared that the coated charcoal did not adsorb only free tracer but also protein bound tracer. This of course is a serious disadvantage of the procedure which could perhaps be overcome by strict standardisation of the method, such as incubation time, pH of the reaction medium, temperature, etc.

In ohopten 3 the charcoal study is continued by considering several aspects of the coating procedure. Here, too, it is concluded that perfect coating is virtually impossible, but much was gained by the use of standardised preparations of both charcanl and dextran.

The eventual substitution of the much used dextran coated charcoal method by a technically easy procedure (protamine sulphate precipitation technique) is cansidered in chapter 4 . From the results obtained in this study there are no reasons to replace the generally recommended dextran coated charcoal procedure by this protamine sulphate precipitation technique. Further investigation might be mecessary.

The protein content in the mamary tumour cytogolg is very important because the receptor activity is expressed as the capacity ta bind labelled oestradiol (fmoles) per mg total cytosol protein. In chapter 5 a methoo: for a sinple, precise and reproducible protein 
determination in small cytosol samples has been proposed.

An improvement in the indication of receptor activity is the expression of oestradiol binding capacity per mg tumor tisue protein in the cytosol. This requires a correction for the presence of serum proteins in the total cytosol protein. This corection can be made by specific immunochemical determination of human serum albumin. Cytosol tumour tissue protein is calculated by subtraction of the serum protein content from the total protein concentration (chapter" 6).

In chapter? the influence of buffer composition, temperature and protein content and lactate concentration of the cytosol and the $\mathrm{pH}$ of the reaction medium was studied. Hithin certain limitis no influence of the variation of the $\mathrm{pH}$ could be found on the results of the receptor analysis. Nevertheless strict standardisation of conditions seems to be advisable including the use of buffers with sulficient capacity.

Characterisacion of oestrogen receptor protelins by several protein separating techniques was studied in chapter 8 . The receptor proteins always appeared in at least two molecular forms probably corresponding to the $4 \mathrm{~S}$ and $8 \mathrm{~S}$ proteins as reported elsewhere.

Considering the different aspects of the determination of oestrogen receptor proteins and the importance of the results of this type of analysis for the clinical treatment and the prognosis of the course of the disease, it is strongly recomended that strict standardisation of the determination should be performed (chaptern 9 ). No unambiguous method for the determination of these receptors can be advised but the E.O.R.T.C. recommended dextran coated charcal procedure appears to be the method of choice at the present time. 


\section{SAMENVATTING}

In hoofdstuk 1 is van de beschikbare literatur een algemeen overzicht gegeven. Met mame is hier ingegaan op de klinische betekenis van de bepaling van oestrogeenreceptoren en ook op de verschillende technieken die voor deze bepaling zijn beschreven. Woortwhoeiend uit deze inleidende beschouwingen is dan het doel van het onderhavig onderzoek geformuleerd: het bestuderen van verschillende aspectem van de bepaling van oestrogeenreceptor-eiwitten in cytosolen van mannat umorweef sel.

Hoofdatuk 2 is de weergave van een uitgebreide studie over het gebruik van dextran-kool bij de bepaling van oestrogeenreceptoren. Er wordt gerapporteerd dat niet allean vije gemerkte hormonen (kleine moleculen) maar ook hormoon-eiwit complexen door de kool worden geadsorbeerd. Hoewel dit als een ernstig bezwar van de beschreven techniek beschouwd wordt is thet niettemin mogelijk door een hoge mate van standardisering wan de reactieomstandigheden toch de bepaling met redelijke betrouwbarkheid wit te voeren. (Dit onderzoek werd eveneens gepubliceerd in Eur. J. Nucl. Med., 1981.)

In hoofdstuk $3 \mathrm{zijn}$ de werschillende aspecten beschreven die betrekking hebben op de "coating" van koolstof met dextran. Voorbehandeling van kool en de samenstelling van het dextrampreparat: (samengesteld uit verschillende fracties met uiteenlopend moleculair geticht) blijjken van belang te zijn, evenals de reactietijd. Voor het bereidem van dextran-kool warmee reproducerbare resultaten kunner worden verkregen, is standardisatie van de coating noodzakelijk. (Gepubliceerd in NucCompact, 1980.)

Gezien de bezwaren, inherent a an de gecoate koolstof methode, its een andere qua techniek voor de routine geschakte, analyse (protatminesulfat precipitatie techniek) nader onderzocht (hoofdstuk 4). De verkregen resultaten rechtvaardigen thiet de vervanging van de over 
het algement anbevalen dextran-hoolstaf methode door deze protaminesultaat precipitatie techniek.

Aandezien de actuiteit wan de receptor-eiwitten ir cytosolen wordt uitgedruk als de specifieke bindingsctiviteit woor gemerkt oestradiol (fnol) per mg cytosolweiwit, is de bepaling hiervan var eminent belang. In hoofdstuk s wordt een eenvoudige en naurkearige methode woot de total-eibitbepaling in kleine cytosol-monsters beschreven. Het totale cytosol-eimit bevat nast cumoreiwitcen steeds ook serumeititten. Een gecorrigeerde cytosol-eiwit warde wordt werkregen door het totale gehalte te verminderen met het gehalte aln serumeithten. Met behulg van een specifieke immunochenische bepaling van human serumalbumine in cytosol-monsters kan genoende correctie worden aangebracht (hoofdgtuk 0 ).

De invloed van buffersamenstelling, temperatury en eiwit-en. laccaacgehalte van de cytosol en van de pll van het reactiemedium wer eveneens bestudeerd (hoofdotuk 7 ). Gebleken is dat binnen bepalde grenzen variatie van de $\mathrm{pH}$ niet noemensward van imvloed is op de oestrogeenreceptor bepaling. Wochtans lijkt ook hier standaardisering van de reactie-omstand igheden geboden.

Karakterisering van bestrogeenreceptor-eiwitten met behulp van verschillende scheidingstechnieken, zoals die bij eiwitonderzoek worden gebruikt, is beschreven in hoofistuk 8 . Steeds werden cenminste twee moleculaire vormen van receptor-eiwit gevonden, warschijnlijk overeenkomend met de in de literatumr vermelde $4 \mathrm{~s}$ en $8 \mathrm{~S}$ eiwitten.

Yoor de behandeling en prognose vam patiënten met mamacarcinoon is do bepalian van oustrogenreceptoren van eminent belang. In de praktijk blijk dat de nawkeurigheid van deze analyses veelal ta wensen owerlaat, warwor werschillende redenen zijn an te voeren. standardisering on unitormering van de bepalingen wordt met klem

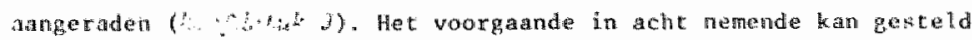
wricen dat de door de F.O.R. T.C. a anbevolen dextran-kool methode, mits stringent fistandatudiseerd, monenteel de meest bruikbare is. 


\section{RESUME}

Le chapiture 1 donne un apercu gểêral de la litterrature traitant de I'importance clinique de la deternination des recepteurs des oestrogènes, décrit brièvement les techniques de dosage de cenx-ci et définit le but de ce travail comme etant l'etude de divers aspects du dosage des recepteurs des oestrogènes dans la fraction soluble cellulaire (cytasol) des tumeurs mamaires.

Le chapitre 2 étudie de manière approfondie l'action du charbondextran dans le dosage; il apparait que la suspension de charbondextran adsorbe mon seulement l'hormone marquee mais aussi une certaine quantite des complexes formés par les proteines et 1 "hormone. Cet inconvểnient non négligeable pourrait tâtre rêduit par une standardisation rigoureuse de l'action de 1 a suspension de charbon dextran sur le cytosol prëincube (durêe de contact, pH et temperrature du gailieu).

L"étude du charbon-dextran se poursuit dans le chapithe 3 out sout exaninés plusieurs paramèrres de 1 "enrobage du charbon par lie dextran. Il est peu probable qu'un enrobage idęl puisse être obtenu mais l"emploi d"une préparation, standardisée utilisant des constituants rigoureusentent définis améliorera la reproductibilité du dosage

Le chopitre Anvisage la possibilité de remplacer la methode utilisant le charbon-dextran par une autre technique aisée pour les analyses de routune et faisant appel ar ure précipitation des proténes par le silfate de protamine "Les résultata obtemus n'apportent pas d'argutient décíif pour ne plus employer la méthode charbon-dextran gënêralement utilisëe; un grand nonbre d'expériences est nécessaire pour dêpartager les deux thêthodes.

L'activite des recepteurs (concentration de sites) s'exprime le plus souvent conme êtant la quantitê d'oestradiol (fmod) líke 
spactiquentent par milligrame de proténes totales du cytosol; le chaph tre 5 propose une methode simple, precise et reproductible de dosage des proténeis dans les cytosols et $n$ "exigeant qu'un faible volume d'echantillon.

I1 suble plus exact d'exprimer lea résultats par milligramme de proténes tissulaires de la tumeur. Cette walleur est obcenue en soustrayant des protétnes totales du cytosiol les protélines sêriques contaminant 1 "échantillom; les derniêres proténes étant calculés a partir de la valeur de la sêrum albunine. Le chapinte bến dêt une méthode valable de dosage specifique de 1 a sêrum albumine humaine dans les cytosols.

Le chapitre 7 "attache à l'influence de divers paramètres modifiant le pll du milieu awant l'incubation avec l'honone (composition des tampons, temperature d"ajustage de leur pH, taux en lactate en proteine des cytosols). Bien qu'aucune influence de la variation de pH n'alt êţ observểe sur les rếsultats des dosages des récepteurs d'oestrogène pour autant que celle-ci reste en deça de certaines limites, il semble préférable de la rêduire autant que possible par" l'emploî d'un tampon standardisé de capacité suffisante.

La caractérisation des récepteurs de l'aestradiol par différentes techniques de geparation des proteines est exposée dang le chapitre 8; 1es rëcepteurs aemblent toujours se présenter sous au moins deux formes moléculaires correspondant vraisemblablement aux protéines sêdimentant à 4 s et $8 \mathrm{~s}$ décrites dans la littérature.

Au vu des differents aspects du dosage des recepteurs de I"oestradiol, il semble qu'il soit nécessaire de produire un effort de standardisation très stricte, 1 "importance des résultats de ce dosage n'étant plus dể duntrer tant en ce qui concerne le traicement clinique que le pronostic d'êvolution du cancer mamaire (chaptete 9 ).

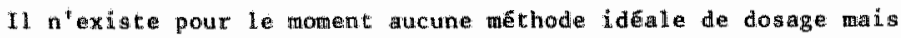
l'Organistation Europénne pour la Recherche et le Traitement du Cancer (E.O.R.T.C.) recommande la mêthode utilisant le charbondextran, laquelle semble etre actuellement la plus satisfaisante. 


\section{ZUSAMMENASSUNG}

Im Kapited 1 wird eine allgemeine Einleitung und ein Dbersicht der vorhandenen Literatur über die klinische Relevanz der GestrogenRezeptor Bestimmung gegeben. Auch die Bestimmangmethoden werden kurz gestreift. Das Ziel der vorliegenden Studie wurde dann folgendermassen formuliert: Die Untersuchung von einigen Aspekten der Gestrogen-Rezeptor Bestimung in Cytosolen aus Mama-Tumorgewebe.

Kapitet 2 befast sich ausfühlich mit der Verwendung von beschichteter A-Kohle bei der Bestimung der Destrogen-Rezeptor Aktivität. Es stellte sich dabei heraus, dass die beschichtete A-Kohle nicht nur freie sondern auch proteingebundene Markierung gsubstanz adsorbiert. Dies ist ein wesenticher Machteil der Methodik, welche möglicherweise durch strikte standardisierung der A-Kohle Inkubation (Inkubationszeit, pll des Reaktionstnediums, Temperatur, U.s.w.) beseitigt werden kam.

In 3. Kapitte? wurden verschiedene Aspekte der A-Kohlebeschichtung näher untersucht. Es wurde auch hier festgeste11t, dass eine perfekte Beschichtung wahrscheinlich nicht möglich ist, wobei jedoch vieles gewonnen wird durch die verwendung von standardisierten A-Kohle- und Dextram-Präparationen.

Es wurde wersucht - wie in Kaptited 4 beschrieben - die vielfach angewendete sog. "Dextran beschichtete A-Kohle Methode" durch eine cechnisch einfache Prozedur (die Protaminesulphat Fïlung) zu ersetzen. Danit wurden jedoch keine besseren Ergebuiste erzielt. Weitere bntersuchungen werden hier notwendig sein.

Weil die Rezeptoraktivitä ais Bindungskapaität für markiertes Destradiol (fmol) per mg cytosol-protein angegeben wird, ift der Proteingehalt in Mamma-Tumot Cytosolen sehr wichtig. Eine genaue wind reproduzierbare Methode zur Bestinmung des Gesamteiweisses in kleinen 
Cytosolproben wurde beschrieben (Kopittel S).

Ts ist exsentiell dass das gemessene Protein Tumor-Eive ass ist. Dies ist nicht intwer der Fall. Es wurde deshalb vorgeschlagen in den glichen cycosolproben auch spezifisch das hume Serumalbumin zu bestimen. Korrektur des Gesamteiweisses tü die konteminierenden serumproteime wird strike emptohlen (kapittel b).

Im Kaptetel 7 wird der Einfluss der Pufferzusamensetsung, der Temperatur, des Protein- und Lactatgehaltes im Cytosol und des pHWertes im Reaktionsmediwn untersucht. Innerhalb bestimnter Grenzen wurde kein Einflugs des pH gefunden, obwobl strikte Standardisierung der Reaktionsbedingungen notwendig zu sein scheint.

Die Charakterisierung der Destrogen-Rezeptor Proteine wurde mit werschiedenem Protein-Trennverfahren studiert (Kapitted B). Die Rezeptorptoteine traten inmer in mindestens zwei molekularen Formen auf, die offenbar korrespondierten mit den an anderer stelle beschriebenen $4 \mathrm{~S}-$ Faktor und $8 \mathrm{~S}-\mathrm{F}$ aktor Proteinen.

In Anbetracht der unterschiedichen Aspekte der OescrogenrezeptorBestinmung und der Wichtigkeit vier Ergebnisse für die kinische Behandlung und Prognosedes Krankheitswerlaufs bel Patientinnen mit Mama Tumoren ist Strikteste Standardisierung der Bestimungsmethode zu empfehlen (Kapittel 9). Obwohl es bis heute roch keine eindeutige Methode zur Bestitunung dieser Rezeptoxen gibt, scheint die won der E.O.R.T.C. empfohllene sog "Dextran beschichtete A-kohle Methode" zur zeit die Methode der wahl zu sein. 


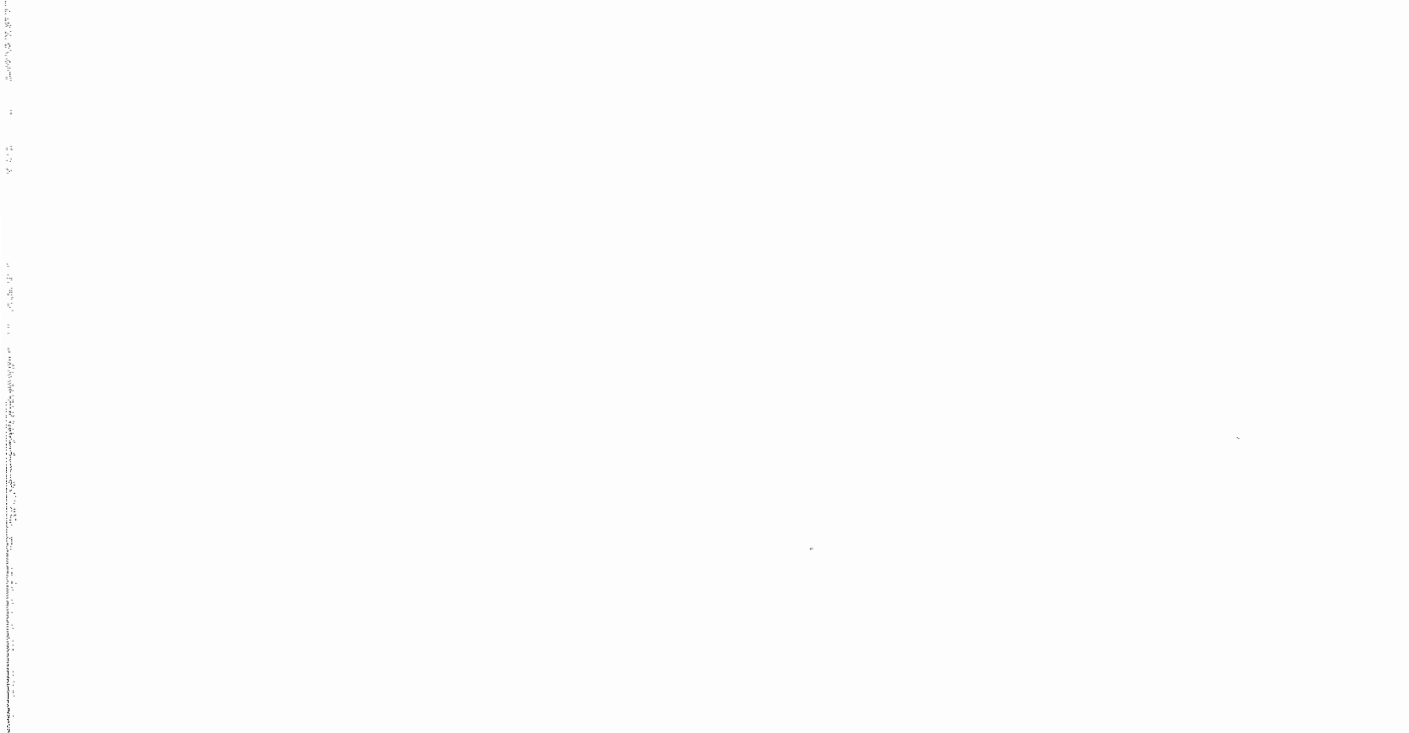


Philippe Guy Fernand Arthur Hector Ralet werd op 6 juni 1945 geboren in Charleroi (België), war hì in 1963 thet eindexamen Humanitês latin-Sciences aflegde not diploma ontving an het Athểée Royal de Charleroi.

Vervolgens studeerde hij ramacie an de kijksumiversiteit te luik wat hem op juli 1970 het diploma van apotheker werd uitgereikt.

Ma een jar als zodanig werkzam te 2 jin geweest, werkte hij gedurende twee jaar als militair-apotheker in het medisch centrum van het belgische leger in Aken.

Daarna verbreedde hij zijn kennis door bet volgen van verschillende post-doctorale stages bij de Universiteit te Luik, en wel bij de Service de Transfusion Sanguine en het Centre de Toxicologie Clinique et Kêdico-lếgale.

Wan 1975 tot december 1978 werkte hij in Duitsland als gespecialiseerd industrie-apotheker in een geneesmiddelenfabriek war hij de verantwoordelijkheid had voor de registratie van geneesmiddelen voor Latijns Anerika en de franstalige landen in Europa en Afrika.

Sinds december 1978 is hij werkzaam geweest op de afdeling klinische chemie (hoofd Prof. Dr. P.J. Brombacher) van thet De WeverZiekenhuis te Heerlen, war hij ook zijn proefschrift bewerkte. 